\title{
ANÁLISE DAS EXPORTAÇÕES BRASILEIRAS DE MADEIRA SERRADA E PAINÉIS À BASE DE MADEIRA NO PERÍODO DE 1961 A 1999
}

\author{
YASKARA MAX RAIMUNDO \\ Bacharel em Ciências Econômicas
}

Orientador: Prof. Dr. CARLOS JOSÉ CAETANO BACHA

Dissertação apresentada à Escola Superior de Agricultura "Luiz de Queiroz", Universidade de São Paulo, para obtenção do título de Mestre em Ciências, Área de Concetração: Economia Aplicada

PIRACICABA

Estado de São Paulo - Brasil

Maio - 2001 


\section{Errata}

RAIMUNDO, Y. M. Análise das Exportações Brasileiras de Madeira Serrada e Painéis à Base de Madeira para o Período de 1961 a 1999.

$\begin{array}{llll}\text { p. } & \text { item } & \text { linha } & \text { onde se lê } \\ 6 & 1.4 & \text { décima segunda } & \begin{array}{l}\ldots \text { a elasticidade-preço } \\ \text { da demanda não é } \\ \text { infinita, ... }\end{array}\end{array}$

33

2.3 décima terceira

77 e $79 \quad 3.2 \quad$ vigésima

segunda e oitava

... a qual fez os preços
em dólar da madeira
serrada aumentar
(Tabela 1) e,
consequentemente, a
quantidade exportada
diminuir (Gráfico 4).

leia-se

... a elasticidade-preço da demanda não é muita grande ou elevada, ... ... a qual fez os preços em reais da madeira serrada caírem e, consequentemente, a quantidade exportada diminuir (Gráfico 4). $\ldots+\log P X_{i}^{i} / P W_{t}^{i}+\ldots \ldots+\log \left(P X_{i}^{i} / P W_{t}^{i}\right)+\ldots$ 
Dados Internacionais de Catalogação na Publicação (CIP) DIVISÄO DE BIBLIOTECA E DOCUMENTAÇÃO - Campus "Luiz de Queiroz"/USP

\section{Raimundo, Yaskara Max}

Análise das exportaçōes brasileiras de madeira serrada e painéis à base de madeira no período de 1961 a 1999 / Yaskara Max Raimundo. - Piracicaba, 2001.

$141 \mathrm{p}$.

Dissertação (mestrado) - - Escola Superior de Agricultura Luiz de Queiroz, 2001. Bibliografia.

1. Comercialização agricola 2. Chapa de madeira 3. Exportação agrícola 4. Indústria madeireira 5. Madeira serrada 6. Mercado externo 7. Oferta e demanda I. Titulo

CDD 338.174983

Rermitida a copia total ou narcial deste documento desde que citala a fonte - Oautor 
Dedico aqueles que sempre estiveram ao meu lado incondicionalmente, minha tia Célia, minha mãe e minha irmã, e aqueles que foram meus maiores incentivadores, Prof ${ }^{a}$. Vera Lúcia Abib Chemin e Prof. Divonir Ribas Teixeira Torres. 


\section{AGRADECIMENTOS}

A Deus, que sempre esteve ao meu lado, em madrugadas passadas em claro, nos momentos de desânimo ... me guiando e me iluminando, todo agradecimento seria pouco.

Ao Prof. Carlos José Caetano Bacha pela dedicada e competente orientação. Suas idéias, diretrizes e críticas deram rumos para este trabalho. Minha eterna gratidão à quem sempre soube compreender e estender a mão.

À CAPES e ao CNPq pelo apoio financeiro materializado através das bolsas de estudos concedidas.

A Clóvis de Oliveira Almeida por suas inúmeras contribuições durante a realização deste trabalho. Sua atenção, suas críticas e conselhos como um todo foram de valor inestimável.

Ao Prof. Rodolfo Hoffmann, pela leitura desta dissertação e pelas valiosas sugestões.

À Prof a . Mirian Rumenos Piedade Bacchi e aos Profs. Evaristo Marzabal Neves e Geraldo Sant'Ana de Camargo Barros pelos úteis e precisos comentários quando da apresentação do projeto de dissertação e da qualificação.

Ao corpo docente do Departamento de Economia, Administração e Sociologia e, em especial, aos Profs. João Gomes Martines Filho e Ricardo Shirota.

Aos amigos que fiz durante o curso de mestrado e, em especial, Adriana, Alesandra, Ana Cláudia, Carla, Cassiana, Ednéia, Lóis, Mariana, Micheli, Regiane, Renata, Rose, Rudi, e Terciso. 
À Ligiana, bibliotecária do Departamento de Economia, Administração e Sociologia, e à Marialice, bibliotecária do IPEF, pela revisão das referências bibliográficas.

Aos funcionários do Departamento de Economia, Administração e Sociologia e, em especial, à Helena, à Maielli, à Luciana e ao Pedro.

Aos Profs. Flávio Ribas Tebchirani e Hermes Higashi do Departamento de Economia da UEPG, pelo apoio e ajuda constante.

Aos meus pais, Asdrubal (in memorian) e Délia, à minha irmã Ana Patrícia e à tia Célia (minha mãe por opção e por amor) que, doando-se inteiros, renunciaram aos seus sonhos para que, muitas vezes, eu pudesse realizar os meus.

Aos meus avós, Pedro Max (in memorian) e Ana Regiani Max (in memorian), pela valiosa contribuição material para minha educação e por terem me ensinado os verdadeiros valores da vida.

À alguém muito especial e que sempre acreditou em mim, Luís Rodrigo Distefano, por fazer parte da minha vida.

Aos meus grandes amigos Léa Márcia Monteiro de Carvalho (que há algum tempo já me chama de "mestre") e Luiz Carlos de Carvalho, que souberam perceber os momentos mais dificeis e auxiliar, minha eterna gratidão.

Ao Tchu, à Carolina e à Fifi pela companhia constante. 


\section{SUMÁRIO}

Página

LISTA DE FIGURAS $\ldots \ldots \ldots \ldots$ iii

LISTA DE GRÁFICOS $\ldots \ldots \ldots \ldots$ iv

LISTA DE QUADROS _...

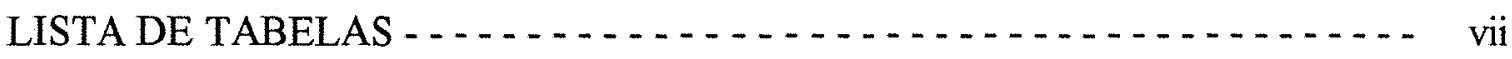

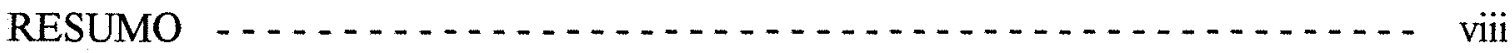

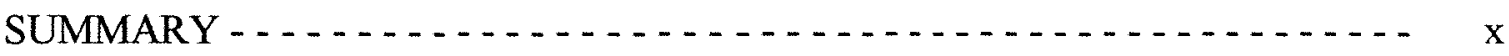

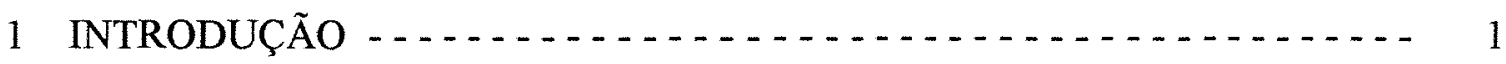

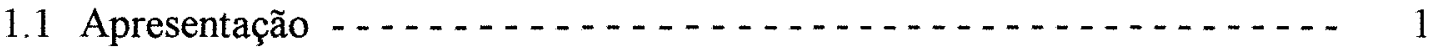

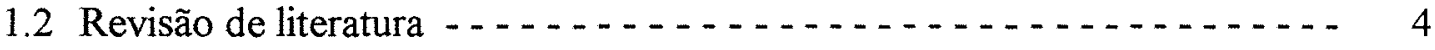

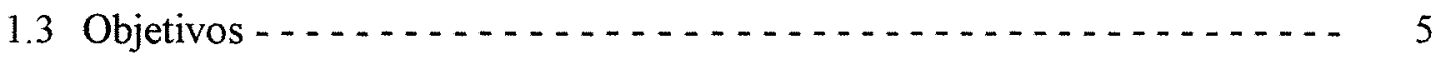

1.4 Hipótese

1.5 Estrutura do trabalho - . . . . . 6

2 EVOLUÇÃO DA INDÚSTRIA BRASILEIRA DE PRODUTOS SÓLIDOS DE MADEIRA E A INSERÇÃO DO BRASIL NO MERCADO

INTERNACIONAL $\ldots \ldots \ldots \ldots \ldots$

2.1 Caracterização dos produtos - .

2.2 A indústria de madeira serrada . . . . . . . . . . . . . . 11

2.3 Evolução das exportações brasileiras de serrados de madeira - . - . - . - 25

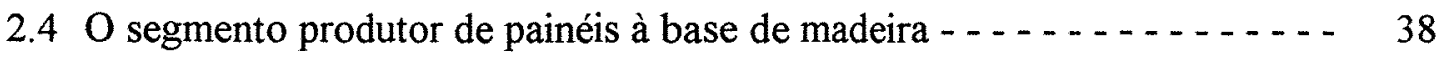

2.4.1 A indústria e as exportações brasileiras de compensado . . . . . 45

2.4.2 A indústria e as exportações brasileiras de aglomerado - . . . - 52

2.4.3 A indústria e as exportações brasileiras de chapas de fibra - . - . 59

3 REFERÊNCIAL TEÓRICO E METODOLÓGICO - . . . . . . . . . . 69

3.1 A hipótese sobre a posição relativa do país frente ao mercado internacional - ........... 69

3.2 O modelo econométrico selecionado _. . . . . . . . . 71

3.3 Fonte de dados - . . . . . 80

4 ESTIMATIVAS DAS EQUAÇÕES DE OFERTA E DEMANDA DE EXPORTAÇÃO DE PRODUTOS SÓLIDOS DE MADEIRA . . . . . . . 82 
4.1 Estimativas das equações de oferta e demanda de exportação de madeira serrada de coníferas e não coniferas

4.1.1 Estimativas das equações de oferta e demanda de exportação de madeira serrada de coniferas ..................... 82

4.1.2 Estimativas das equações de oferta e demanda de exportação de

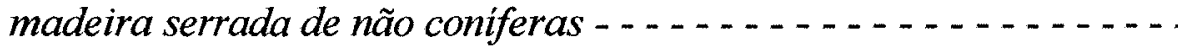

4.2 Estimativas das equações de oferta e demanda de exportação de painéis à base de madeira . . . . . . . . . . . . . . . . . . . . . . . . . 91

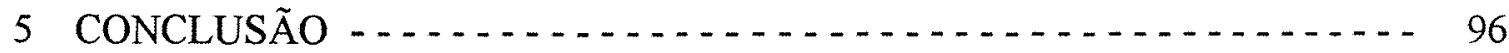

REFERÊNCIAS BIBLIOGRÁFICAS _. $\ldots \ldots . \ldots 103$

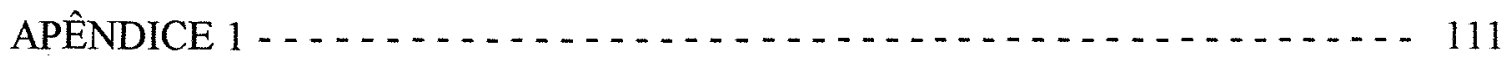

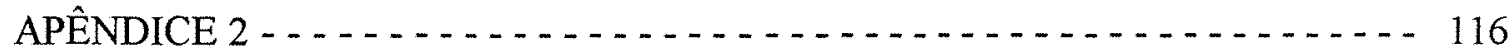

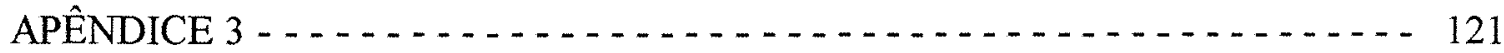




\section{LISTA DE FIGURAS}

Página

1 Classificação dos produtos oriundos da madeira em tora 8 


\section{LISTA DE GRÁFICOS}

Página

1 Evolução da produção brasileira de madeira serrada no período de 1961 a 1999

2 Principais países produtores de madeira serrada em 1999

3 Evolução das exportações brasileiras de madeira serrada no período de 1961 a 1999

4 Evolução das exportações brasileiras de madeira serrada de coniferas e não coníferas no período de 1961 a 1999

5 Principais países de destino das exportações brasileiras de madeira serrada em 1998

6 Evolução da produção mundial de madeira serrada de coníferas e não coníferas no periodo de 1961 a 1999

7 Evolução da produção mundial de painéis à base de madeira no período de 1961 a 1999

8 Evolução da participação da produção dos principais grupos de painéis sobre a produção mundial do agregado painéis à base de madeira no período de 1961 a 1999

9 Principais paises produtores de painéis à base de madeira em 1999

10 Evolução da produção brasileira de painéis à base de madeira e sua proporção em relação à produção mundial no período de 1961 a 1999

11 Principais países exportadores de painéis à base de madeira em 1999

12 Evolução das exportações brasileiras de compensado no período de 1961 a 1999

13 Principais empresas exportadoras de painel de compensado no Brasil em 1996

14 Evolução das exportações brasileiras de aglomerado no período de 1972 a 1999 
15 Principais países de destino das exportações brasileiras de chapas de 62 fibra em 1998

16 Evolução das exportações brasileiras de chapas de fibra prensada no 63 período de 1961 a 1999 


\section{LISTA DE QUADROS}

Página

1 Capacidade instalada das unidades de serrados no Brasil em 1998

2 Principais embargos e restrições ao comércio de madeiras tropicais

3 Capacidade instalada da indústria de compensado em países selecionados em 1998

4 Capacidade instalada da indústria brasileira de painéis de aglomerado em 1998

5 Capacidade instalada esperada para a indústria brasileira de MDF no final de 2001 


\section{LISTA DE TABELAS}

Página

1 Valor unitário das exportações mundiais de madeira serrada em anos selecionados

2 Maiores exportadores mundiais de madeira serrada em anos selecionados

3 Market Share nos principais países importadores de madeira serrada brasileira de não coníferas em anos selecionados

4 Market Share nos principais países importadores de painel de compensado brasileiro

5 Maiores exportadores mundiais de painel de aglomerado em anos selecionados

6 Preços médios de painéis de aglomerado praticados no mercado interno

7 Maiores exportadores mundiais de chapas de fibra comprimida em anos selecionados

8 Produção, importação, exportação e consumo aparente de MDF no Brasil no período de 1997 a 1999

9 Estimativa das equações estruturais da oferta de exportação de madeira serrada de coniferas

10 Estimativa das equações estruturais da demanda de exportação de madeira serrada de coníferas

11 Estimativa da equação estrutural da oferta de exportação de madeira serrada de não coniferas para o período de 1970 a 1999

12 Estimativa da equação estrutural da demanda de exportação de madeira serrada de não coníferas para o período de 1970 a 1999

13 Estimativa da equação estrutural da oferta de exportação de painéis à base de madeira para o período de 1961 a 1999

14 Estimativa da equação estrutural da demanda de exportação de painéis à base de madeira para o período de 1961 a 1999 


\title{
ANÁLISE DAS EXPORTAÇÕES BRASILEIRAS DE MADEIRA SERRADA E PAINÉIS À BASE DE MADEIRA NO PERÍODO DE 1961 A 1999
}

\author{
Autora: YASKARA MAX RAIMUNDO \\ Orientador: CARLOS JOSÉ CAETANO BACHA
}

\section{RESUMO}

Este trabalho analisa o comportamento das exportações brasileiras de madeira serrada e painéis à base de madeira no periodo de 1961 a 1999. Para tanto, a evolução das indústrias de madeira serrada e painéis à base de madeira e a inserção do Brasil no mercado internacional desses produtos são analisadas. Em seguida, é especificado um modelo simultâneo de oferta e demanda de exportação para os seguintes produtos: madeira serrada de coníferas, madeira serrada de não coníferas e painéis à base de madeira. Os modelos de ajustamento do balanço de pagamentos e os trabalhos empíricos que tratam das exportações brasileiras de manufaturados são utilizados para auxiliar no processo de seleção das variáveis a serem incluídas nas equações. As exportações de madeira serrada de coníferas são estimadas em dois períodos distintos, quais sejam, 1961 a 1987 e 1988 a 1999. Isso se deu devido uma quebra de tendência (testada estatisticamente por meio do ajustamento de uma poligonal) observada na evolução dessas exportações, resultado de mudanças importantes na composição da pauta de exportações de madeira serrada de coníferas. Porém, os resultados econométricos obtidos para os dois subperíodos analisados não são satisfatórios. As estimativas das equações de oferta e demanda de exportação de madeira serrada de não coníferas são satisfatórias. A oferta de exportação se mostra 
sensível a variações de preços. A dificuldade de introdução de novas espécies no mercado internacional e as inúmeras restrições ambientais se refletem em baixa elasticidade-renda na equação de demanda e em um coeficiente negativo para a variável produção na equação de oferta. Os resultados encontrados para as exportações de painéis de madeira indicam uma oferta elástica com relação ao preço e bastante sensível com relação às flutuações no mercado interno. A baixa elasticidade-renda da demanda de exportação de painéis de madeira reflete a dificuldade de inserção do Brasil no mercado internacional desses produtos. $O$ trabalho termina por concluir que tanto fatores de oferta quanto fatores de demanda foram importantes na determinação das exportações brasileiras de madeira serrada e painéis à base de madeira no período de 1961 a 1999. Assim, a hipótese do "pais pequeno" e que, portanto, depara-se com uma função de demanda externa por suas exportações infinitamente preço-elástica não parece plausivel. 


\title{
THE ANALYSIS OF THE BRAZILIAN SAWNWOOD AND WOOD-BASED PANELS EXPORTS - FROM 1961 TO 1999
}

\author{
Author: YASKARA MAX RAIMUNDO \\ Adviser: CARLOS JOSÉ CAETANO BACHA
}

\section{SUMMARY}

This paper analyzes the performance of Brazilian sawnwood and wood-based panels from 1961 to 1999. Two steps are pursued: first, the evolution of sawnwood and wood-based panels and their insertion in international trade were analyzed. Second, an simultaneous econometric model of supply and demand of these products were built. The criteria used to choose the dependent variables in this model was the analysis of the theoretic models of trade balance adjustment and the evaluation of applied papers about the Brazilian exports of industrial goods. The econometric model was built in order to permit the analysis of conifer sawnwood, non-conifer sawnwood and wood-based panels exports separately. The equations of conifer sawnwood exports were estimated for two periods: from 1961 to 1987 and from 1988 to 1999. These exports decreased during the first period and raised in the second one. The inflexion on export curve was evaluated econometrically, using a polygonal adjustment model. However, the econometric results for the two set of conifer sawnwood export equations were not satisfactory. Otherwise, the estimations of non-conifer sawnwood export equations showed satisfactory results. The export offer is sensible to price fluctuations. The low value of income-elasticity of export demand and the negative signal of production variable in supply curve were explained by the difficult of trading 
news species of sawnwood in international markets and the environmental restrictions that have happened in some importing countries. The wood-based panels supply is priceelastic and also it is very sensible to domestic demand fluctuations. The low value of the income-elasticity of demand for these products is explained by the difficult of Brazil in enlarging its share in international markets of wood-based panels. At the end, this paper concludes that both supply and demand factors are important in the determination of the Brazilian sawnwood and wood-based panels exports, during the time period from 1961 to 1999. Therefore, the hypothesis of small country and consequently an infinitely price-elasticity demand curve are not appropriate to analyze the export of these products in Brazil. 


\section{INTRODUÇÃO}

\subsection{Apresentação}

O presente trabalho analisa o comportamento das exportações brasileiras de madeira serrada e painéis à base de madeira no período de 1961 a 1999. Para tanto, são estimadas funções de oferta e de demanda de exportação, utilizando um modelo de equações simultâneas.

O mercado de produtos sólidos de madeira compreende, genericamente, as transações comerciais com madeira em tora, madeira serrada, laminados e compensados e produtos derivados de cavacos e/ou resíduos (caso dos aglomerados e chapas de fibras). Os produtos sólidos de madeira mais representativos, em termos comerciais, sào a madeira serrada e os painéis à base de madeira, o que limitou o presente estudo a esses dois produtos. Ao longo do trabalho, a expressão produtos sólidos de madeira será usada como sinônimo para madeira serrada e painéis à base de madeira.

A indústria de madeira serrada compreende a produção de vários produtos, destacando-se os dormentes, madeira aplainada, beneficiada, semi-elaborada, perfis, vigas, entre outros, com espessura normalmente superior a $5 \mathrm{~mm}$.

Os painéis à base de madeira dividem-se em três grandes grupos, quais sejam, laminados e compensados, aglomerados e chapas de fibras. Esses produtos são conhecidos como derivados da madeira e outros materiais lignocelulósicos, consistidos de fibras vegetais, partículas, lascas, elementos ou lâminas aglutinados através de resinas sintéticas. 
O comércio mundial de madeiras provenientes dos vários tipos de florestas movimentava anualmente, em meados da década de 90 , cerca de US $\$ 50$ bilhões, sendo que, deste total, aproximadamente US\$12 bilhões eram originários das florestas tropicais. A participação do Brasil nesse mercado, entretanto, tem sido bastante modesta, visto que ele comercializa apenas $2 \%$ da madeira proveniente de todas as florestas e 4,5\% quando se trata da comercialização de madeiras originadas de florestas tropicais (Macedo et al., 1997).

As transações internacionais relativas à madeira serrada, que é o produto mais negociado no mercado de produtos sólidos de madeira, envolveram, em 1999 , cerca de US\$24 bilhões, correspondentes a, aproximadamente, 120 milhões de $\mathrm{m}^{3}$. A relação exportação/produção de madeira serrada evoluiu de 12\% em 1961 para cerca de $27,8 \%$ em 1999. O Brasil, em termos de comércio internacional, posicionou-se, em 1999, como quarto principal país exportador de não coníferas, vindo logo depois dos Estados Unidos, da Malásia e do Canadá.

O comércio de painéis à base de madeira movimentou, em 1999, cerca de US $\$ 17,5$ bilhões, correspondentes a, aproximadamente, 52 milhões de $\mathrm{m}^{3}$, o que representa um crescimento de $69,9 \%$ em relação a 1990 , quando as transações desses produtos totalizaram pouco mais de 30,6 milhões de $\mathrm{m}^{3}$. A participação do Brasil neste mercado, embora bastante modesta, cerca de $2,5 \%$ do total, apresentou crescimento de $127,3 \%$ no mesmo período, passando de $616 \mathrm{mil} \mathrm{m}^{3}$ para mais de 1,4 milhão de $\mathrm{m}^{3}$.

Como destacam Nahuz \& Watai (1998), entre os múltiplos produtos do setor florestal-madeireiro, os painéis à base de madeira têm sido aqueles que apresentaram o mais rápido crescimento, não só em demanda e produção, mas também na diversidade de tipos e qualidades e na rapidez com que seus produtores têm incorporado crescentes níveis de tecnologia.

Segundo dados da Organização das Nações Unidas para a Agricultura e Alimentação (FAO), citados em Macedo \& Roque (1997), haverá, num futuro próximo, um desajustamento crescente entre oferta e demanda de madeira no mercado 
internacional, em função, basicamente, da queda na produção da Malásia e Indonésia (dado o comportamento histórico de exploração intensiva das suas reservas florestais) e pela estagnação na produção dos principais países produtores do hemisfério norte, frente a pressões de natureza ambiental. Esses fatores reforçam a asserção da gradativa mudança do eixo de produção de madeira do hemisfério norte para o sul e colocam o Brasil diante da oportunidade de aumentar sua inserção nos mercados de grande competição e volumes.

Soma-se a esse cenário internacional favorável as vantagens comparativas do Brasil em crescimento vegetativo das árvores e competitividade em custos de produção. Como observa Flândoli Sobrinho (1995), a vantagem comparativa em crescimento no Brasil é inquestionável e, adicionalmente, o país tem condições climáticas, de solo e áreas disponíveis, que permitem testar uma gama de diversas espécies, de espaçamentos, escolha de material genético e técnicas diferentes de manejo.

É ilustrativo, no que diz respeito à velocidade de crescimento das plantações florestais, que no Brasil as árvores de eucalipto podem ser cortadas, em média, sete anos após o plantio. Na Indonésia, por exemplo, o corte de acácia e eucalipto se dá em oito anos. Na península ibérica, o corte de eucalipto é feito de doze a quinze anos após o plantio. Na América do Norte e Escandinávia, outras espécies equivalentes no uso só são cortadas de vinte a noventa anos após o plantio.

Além da capacidade e das condições de implantar espécies florestais de rápido crescimento, o Brasil possui a maior reserva florestal de madeira tropical do mundo e condições bastante favoráveis de demanda pelas dimensões e dinamismo do mercado interno de produtos sólidos de madeira. Isto tem motivado grandes grupos nacionais e estrangeiros a investir em novas plantas industriais, trazendo tecnologias para a indústria de madeira serrada e painéis de madeira até então inexistentes no País.

Resta finalmente observar, no que diz respeito a demanda mundial, que estimativas revelam que as taxas de crescimento do consumo para os produtos sólidos de madeira estão entre $1,2 \%$ e $3,4 \%$ ao ano. O consumo mundial de madeira serrada vai 
crescer dos 456 milhões de $\mathrm{m}^{3}$ registrados em 1991 para 786 milhões de $\mathrm{m}^{3}$ por volta de 2010, enquanto o consumo de painéis à base de madeira crescerá de 121 milhões para 313 milhões de $\mathrm{m}^{3}$ no mesmo período.

\subsection{Revisão de literatura}

Existe no Brasil uma quantidade ampla e crescente de trabalhos empíricos sobre equações de comércio e, em particular, sobre equações de exportação. A literatura dispõe, ainda, de uma série de estudos que se destinam a avaliar especificamente o comportamento das exportações de produtos manufaturados. Entre estes trabalhos pode-se citar o de Doellinger et al. (1973), Lemgruber (1976), Carvalho \& Haddad (1978), Pinto (1980), Cardoso \& Dornbusch (1980), Lopes \& Resende (1981), Musalem (1981), Tyler (1982), Braga \& Markwald (1983), Pinto (1983), Zini Júnior (1988), Portugal (1993), Amazonas \& Barros (1995), Castro \& Cavalcanti (1998) e Cavalcanti \& Ribeiro (1998).

Não obstante, poucos são os trabalhos econométricos que se destinam a analisar o comportamento das exportações de produtos sólidos de madeira. Além disso, esses estudos não se referem à madeira serrada e aos painéis à base de madeira no agregado, tratando, apenas, de um desses grupos, quando não de uma espécie de produto sólido exportado. Entre esses poucos trabalhos, pode-se citar o de Angelo (1998), Angelo \& Silva (1998) e Sperandio \& Keinert Júnior (1989).

Angelo (1998) estimou modelos simultâneos de oferta e demanda para as exportações brasileiras de madeira serrada tropical para o periodo de 1972 a 1994 . Usando mínimos quadrados de três estágios, o autor obteve elasticidade da demanda e da oferta pouco sensíveis aos preços, enquanto a elasticidade-preço cruzada da demanda indicou a substituição das madeiras serradas tropicais pelas folhosas no mercado internacional.

Angelo \& Silva (1998), considerando a hipótese de país pequeno, estimaram um modelo dinâmico de oferta de exportação da madeira serrada do mogno 
para o Brasil. As variáveis explicativas consideradas foram a remuneração real das exportações, os ciclos da demanda interna, a expansão da malha viária na Amazônia e a restrição ao livre comércio de toras (avaliada por uma variável dummy). As estimativas por mínimos quadrados ordinários para o periodo de 1972 a 1993 mostraram que todas as variáveis explicativas contribuíram para explicar o comportamento das exportações da madeira serrada do mogno e que não houve defasagem no ajuste das exportações. A elasticidade-preço da oferta encontrada foi 1,19, o que caracteriza a oferta de mogno como sendo moderadamente elástica.

Sperandio \& Keinert Júnior (1989), utilizando dados de série temporal trimestral para o período de 1980 a 1986, estimaram por mínimos quadrados de dois estágios um modelo estático de oferta e demanda de compensado para o estado do Paraná. A elasticidade-preço da demanda foi estimada em -0,83 e a elasticidade-preço da oferta em 0,91 .

A avaliação dos fatores que afetam as exportações de produtos que são superavitários na balança comercial, como é o caso da madeira serrada e dos painéis à base de madeira, é essencial em um momento onde o Brasil procura melhorar o saldo de sua balança comercial. No entanto, esta análise ainda não foi realizada satisfatoriamente.

\subsection{Objetivos}

O objetivo geral deste trabalho é analisar o comportamento das exportações brasileiras de madeira serrada e painéis à base de madeira no período de 1961 a 1999. Para tanto, são estimadas funções de oferta e de demanda de exportação, utilizando um modelo de equações simultâneas.

Especificamente, pretende-se:

a) analisar a evolução das indústrias de madeira serrada e de painéis à base de madeira e a inserção do Brasil no mercado internacional desses produtos. Procura-se, através de análise tabular e gráfica, 
analisar as mudanças que ocorreram na produção e exportação dos produtos em análise nas últimas quatro décadas;

b) especificar as estruturas de oferta e demanda para as exportações brasileiras de produtos sólidos de madeira, no contexto de um modelo simultâneo;

c) estimar as equações de oferta e demanda de exportação de madeira serrada e de painéis à base de madeira e avaliar a relevância das principais variáveis que afetam o comportamento das exportações desses produtos.

\subsection{Hipótese}

Apesar do Brasil ser considerado "um país pequeno" frente ao mercado internacional de produtos sólidos de madeira, a elasticidade-preço da demanda não é infinita, dado que os pressupostos básicos da concorrência perfeita não se verificam, por serem os produtos sólidos de madeira diferenciados na ótica do consumidor e inúmeras as restrições ao livre comércio desses produtos.

\subsection{Estrutura do trabalho}

O presente trabalho está organizado em quatro capítulos, além desta introdução. O capítulo 2 analisa a evolução das indústrias de madeira serrada e de painéis à base de madeira e a inserção do Brasil no mercado internacional desses produtos. $\mathrm{O}$ capítulo 3 discute a fundamentação teórica e metodológica das equações de oferta e demanda de exportação de produtos sólidos de madeira, suas especificações e os dados necessários para sua estimação. As estimativas das equações de exportação de madeira serrada e painéis à base de madeira para o Brasil estão no capítulo 4, o qual também analisa os principais fatores determinantes destas exportações. $\mathrm{O}$ capítulo 5 apresenta as conclusões do trabalho. 


\section{EVOLUÇÃO DA INDÚSTRIA BRASILEIRA DE PRODUTOS SÓLIDOS DE MADEIRA E A INSERÇÃO DO BRASIL NO MERCADO INTERNACIONAL}

Inicialmente (item 2.1) é feita a caracterização dos produtos sólidos de madeira. Em seguida (item 2.2) é analisada a evolução da indústria de madeira serrada, destacando os aspectos da estrutura desta indústria que afetam as exportações brasileiras de madeira serrada. A análise destas exportações é feita no item 2.3, quando se compara a performance do Brasil neste mercado com a de outros países, e se destacam alguns fatores que têm afetado as exportações brasileiras de madeiras serradas. A análise das indústrias de painéis de madeira e das exportações desses produtos é feita no item 2.4.

\subsection{Caracterização dos produtos}

O presente estudo obedeceu à categorizarão e nomenclatura da FAO (Food and Agriculture Organization of the United Nations), conforme está apresentada na Figura 1.

A indústria de madeira serrada compreende a produção, entre outros produtos, de dormentes, madeira aplainada, beneficiada, semi-elaborada, perfis, vigas, sarrafos, com espessura normalmente superior a $5 \mathrm{~mm}$. Esses produtos são elaborados com o emprego de madeiras classificadas comercialmente como softwood (as provenientes de coníferas ${ }^{1}$ ) e hardwood (as originadas de não coníferas ou folhosas ${ }^{2}$ ).

\footnotetext{
${ }^{1}$ As coniferas são árvores classificadas botanicamente como gymnopermae, com madeira de cor clara, macia (softwood), e que apresentam fibra longa e densidade uniforme. Essas árvores são encontradas em regiões onde o clima varia de temperado a frio. A araucária e o pinus são exemplos de árvores coníferas.

2 As não coniferas ou folhosas compreendem as árvores classificadas botanicamente como angiospermae, com madeira de cor e densidade variada, dura (hardwood) e dotadas de fibra curta. Essas árvores são encontradas em regiões de clima temperado e tropical. Exemplos de não coníferas são o mogno, o cedro e o eucalipto.
} 


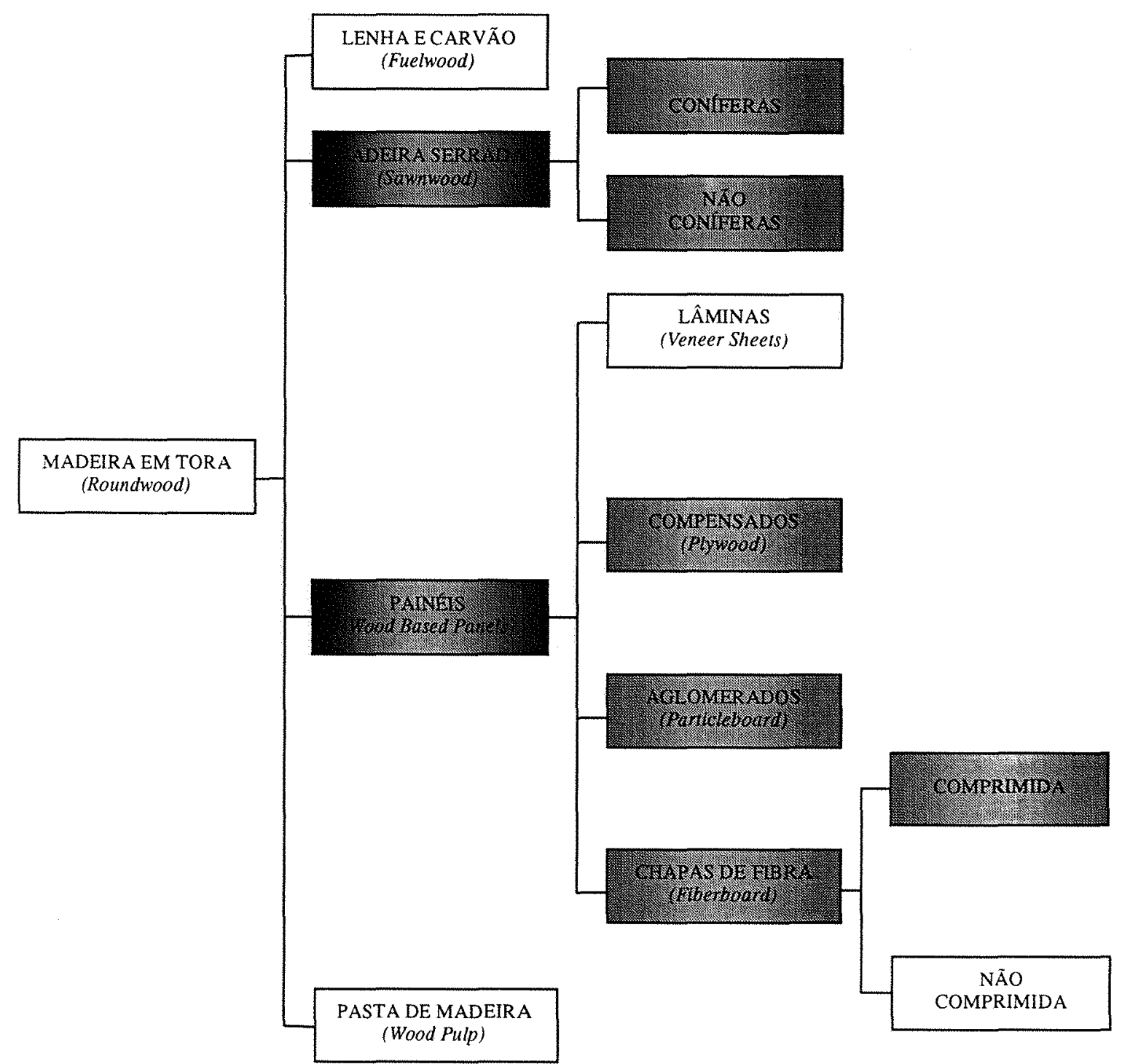

Figura l Classificação dos produtos oriundos da madeira em tora

Os produtos de madeira classificados como serrados são utilizados, sobretudo, nas indústrias moveleira, de embalagens e da construção civil. 
Os painéis à base de madeira compõem um grupo de produtos com grande diversidade, substitutos entre si para algumas aplicaçoes. O principal uso desses produtos é na indústria moveleira e na construção civil, tanto para a fase estrutural quanto para a de acabamento. A nomenclatura aqui utilizada divide os painéis em quatro tipos principais, quais sejam, lâminas, compensados, aglomerados e chapas de fibra.

As lâminas, internacionalmente conhecidas como veneer, são, na verdade, insumo para a fabricação de painéis, sendo também utilizadas diretamente na indústria moveleira.

Os compensados (plywood) ou contraplacados são obtidos pela colagem de lâminas de madeira sobrepostas, com as fibras cruzadas perpendicularmente, formando painéis de grande resistência física e mecânica. A madeira compensada é produzida sob duas principais especificações, a saber, para uso interno (moisture resistent), com colagem à base de resina de uréia-formol, e para uso externo (boilling water proof), com colagem à base de resina de fenol-formol. A denominação de compensado sarrafeado (block board) se refere a um compensado cuja alma ou miolo é composta pela colagem de sarrafos, ao invés de lâminas de madeira.

A madeira compensada tem múltiplas aplicações em móveis, embalagens, formas de concreto, na construção civil, etc. Suas características mecânicas, suas grandes dimensões e seus vários tipos adaptáveis a usos diversos, constituem os principais atributos para justificar a ampla utilização desses painéis.

Os painéis de aglomerado são obtidos a partir de partículas de madeira ou outros materiais, aglutinados por meio de resina e, em seguida, submetidos a um ciclo de temperatura e pressão. A resina normalmente utilizada é a uréia-formaldeído e, também, o fenol-formaldeído, quando há necessidade de melhores características de resistência. As principais fontes de matéria-prima utilizadas na fabricação de madeira aglomerada são os resíduos industriais, resíduos de exploração florestal, madeira de qualidade inferior não industrializáveis de outra forma, madeira proveniente de florestas plantadas e reciclagem de madeira sem utilização. 
O painel de aglomerado pode ser pintado ou revestido com vários tipos de materiais, entre outros, papéis impregnados com resinas melamínicas, papéis envernizáveis e lâminas de madeira natural. A madeira aglomerada possui ampla utilização na indústria moveleira, na fabricação de racks, caixas acústicas, gabinetes de televisão e, de forma secundária, na indústria da construção civil.

Os painéis chamados de chapa de fibra (fiberboard) se subdividem, de acordo com o processo de fabricação, em comprimidos e não comprimidos. Esses produtos são obtidos a partir de um intenso desfibramento dos cavacos de madeira, resultando em uma placa rígida e homogênea. As chapas de fibra comprimida, por sua vez, subdividem-se em chapa de fibra dura (hardboard) e MDF (Medium Density Fibreboard).

O hardboard, painel popularmente conhecido como "chapa de eucatex", é reconstituído a partir de madeira desfibrada, aglutinada com resina, uréia e formol, prensada termodinamicamente e com densidade superior a $0,80 \mathrm{~g} / \mathrm{cm}^{3}$. O hardboard é um produto substituto do compensado, de ampla utilização na construção civil para o revestimento de portas e paredes, divisórias, etc.; na indústria automobilística, no revestimento de portas laterais, estofamentos e consoles; na indústria moveleira, principalmente para fundos de gavetas e armários.

O MDF é uma chapa produzida a partir de fibras de madeira aglutinadas com resinas sintéticas e pela ação conjunta de temperatura e pressão. $\mathrm{Na}$ obtenção das fibras, a madeira é cortada em pequenos cavacos que, em seguida, são triturados por meio de desfibradores. $\mathrm{O}$ MDF apresenta densidade em torno de $0,70 \mathrm{~g} / \mathrm{cm}^{3}$, intermediária entre o painel de aglomerado e do hardboard, e com consistência e algumas características mecânicas que se aproximam às da madeira maciça.

A homogeneidade proporcionada pela distribuição uniforme das fibras permite ao MDF acabamentos do tipo envernizamento, pinturas em geral ou revestimentos com papéis decorativos, lâminas de madeira ou PVC. As chapas de MDF 
são fabricadas com diferentes características, que variam em função da sua utilização final. Além das chapas standard, existem as chapas FR (resistentes ao fogo), as chapas MR (resistentes à umidade, usadas em ambientes externos) e as HD, chapas de grande resistência mecânica fabricadas com maior quantidade de fibras e resinas, o que thes permite aplicações que requeiram maior resistência à flexão e ao impacto. As espessuras das chapas variam de $3 \mathrm{~mm}$ até $60 \mathrm{~mm}$, sendo as mais grossas utilizadas em elementos estruturais ou decorativos de arquitetura e móveis.

\subsection{A indústria de madeira serrada}

A atividade de exploração madeireira no Brasil teve início na época do descobrimento do País, quando foram exploradas as florestas da orla marítima. Esta atividade se desenvolveu, ao longo do tempo, de forma extrativa e baseada na exportação de toras. No entanto, em grande proporção, as florestas foram extintas para dar lugar ao processo de expansão da agropecuária e pouco se desenvolveu a indústria madeireira. Apenas no começo do século XX, com a industrialização da Araucária angustifólia, é que se inicia uma nova fase para a indústria madeireira.

A indústria de madeira serrada no Brasil se desenvolveu inicialmente na Região Sul. Conforme Zaniollo (1988), entre os fatores que foram determinantes no estabelecimento, na fase precursora, da indústria de serrados naquela região, estavam as grandes reservas de pinheirais e a chegada de imigrantes que tinham o costume de usar madeira em suas construções e detinham o know-how de seu processamento. Foram os imigrantes europeus que instalaram as primeiras serrarias. Inicialmente precárias, essas serrarias funcionaram com as chamadas serras de centro, surgindo posteriormente máquinas mais aperfeiçoadas como a tissot ou francesa, até aparecerem as primeiras serras de fita importadas.

A industrialização da madeira foi crescendo com rapidez, pois além da floresta representar um obstáculo natural à expansão da área agrícola, a industrialização e comercialização da madeira se mostrou uma atividade bastante rentável (sobretudo 
pela valorização do pinho no mercado externo). Muitos agricultores passaram então a se dedicar inteiramente a esta atividade.

A preocupação com o corte sem nenhum controle das reservas nativas de araucária levou à criação, em 1941, do Instituto Nacional do Pinho (INP), órgão que respondeu, entre outras funções, pela promoção ao reflorestamento.

Em 1966. foi fundado o Instituto Brasileiro de Desenvolvimento Florestal (IBDF) e promulgado o decreto-lei 5.106, de 02.09.66, que regulamentou os incentivos fiscais, previstos no Código Florestal de 1965, destinados a gerar recursos para a implantação de maciços florestais. $O$ referido decreto permitiu às pessoas físicas e jurídicas abaterem parte do imposto de renda devido para aplicações em atividades de reflorestamento.

Os resultados parciais dos incentivos fiscais podem ser avaliados pela grande extensão da área reflorestada até 1986, último ano onde houve aprovação de novos projetos. Os incentivos fiscais deveriam ter viabilizado o plantio de quase 6,3 milhões de hectares de florestas, com destaque para o Pinus $s p$ e Eucalyptus $s p$, com cerca de $30 \%$ e $50 \%$, respectivamente, da área reflorestada.

A partir da segunda metade da década de 60 , várias associações e institutos, além do IBDF, foram criados, objetivando um aprofundamento nas pesquisas e busca de desenvolvimento tecnológico no que tange aos projetos de implantação florestal. Podendo-se citar, entre outros, o Instituto de Pesquisas e Estudos Florestais (IPEF); a Fundação de Pesquisas e Estudos Florestais do Paraná (FUPEF); a Sociedade de Investigações Florestais (SIF); a Fundação e Desenvolvimento de Pesquisa (FUNDEP) e o Conselho Nacional de Pesquisa de Florestas da Empresa Brasileira de Pesquisa Agropecuária (CNPF/EMBRAPA).

O auge da produção de madeira serrada na Região Sul do Brasil, segundo Azeredo (1988), ocorreu nas décadas de 50 e 60, quando praticamente inexistia produção de madeira em outras regiões. A partir de meados dos anos 70 , a produção de 
madeira serrada começou a declinar, já evidenciando a exaustão das reservas esteadas na araucária e em algumas folhosas nobres como cedro, canelas, peroba, etc.

O aumento do número de serrarias na Região Sul, em grande parte no Estado do Paraná, que passou de 667 unidades instaladas até a década de 70 para 2345 nos anos 80 , acelerou a redução das reservas nativas nessa região ${ }^{3}$. A partir da década de 80 , começa a produção de serrados procedentes de florestas plantadas, provocando grande mudança na estrutura de produção da Região Sul.

Pari passu a exaustão das reservas nativas da Araucária angustifólia, a Região Norte, conforme Zaniolo (1988), assumiu a hegemonia na produção e exportação de serrados baseados em folhosas. Mercado \& Campagnani (1988) observam que a cobertura vegetal e a extrema facilidade de ingresso nesta atividade, entre outros fatores, alavancaram a produção naquela região, elevando de 84 o número de unidades produtoras de serrados em 1952 para 793 em 1978, compreendendo 2231 unidades produtoras em 1986. Segundo Angelo (1998), em 1989, operavam na região Amazônica 2892 serrarias e, em 1998 esse número chega a cerca de 6000 unidades.

Mercado \& Campagnani (1988) apontam algumas razões para esse crescimento das serrarias na Região Norte, conforme segue:

a) a entrada na indústria de serrados é facilitada pelo reduzido nível tecnológico com o qual as serrarias operam, de modo que as firmas que se instalam na Amazônia não vêm necessidade de operar com serrarias modernas, reativando muitas vezes serrarias paradas há algum tempo, o que se traduz em reduzido investimento inicial;

b) elevada oferta de mão-de-obra, devido ao baixo grau tecnológico adotado por essas empresas, permitindo que operários sem

\footnotetext{
${ }^{3}$ Segundo Zaniollo (1988), a partir de 1970, também cresceu o número de empresas moveleiras instaladas no Estado do Paraná, alcançando em 1987, 1520 estabelecimentos de um total de aproximadamente 16 mil instaladas em todo o Brasil. Estas dinamizaram no mercado interno o uso das madeiras tropicais e coníferas do sul.
} 
qualquer qualificação possam ser treinados em pouco tempo para suas funções;

c) os vastos recursos florestais da Amazônia, cuja área de exploração situa-se na proximidade de rios e estradas, facilitando a obtenção de matéria-prima;

d) o mercado absorve toda a produção, de modo que as serrarias existentes não se opõem à entrada de novas empresas.

Cumpre destacar que a ausência de barreiras à entrada na indústria de madeira serrada implica, conforme Santos (1996), condições precárias de produção, baixo nível de produtividade, reduzido grau de automação, produtores desatualizados em termos de modernização industrial e má qualidade dos produtos.

Segundo a Associação Brasileira da Indústria de Madeira Processada Mecanicamente - ABIMCI (1999), o parque industrial brasileiro voltado a produção de serrados conta com cerca de 9630 unidades produtoras, onde grande parte são de pequeno porte e apenas $0,7 \%$ delas apresentam capacidade de produção média e grande, conforme mostra o Quadro 1.

\section{Quadro 1}

Capacidade instalada das unidades de serrados no Brasil em 1998

\begin{tabular}{|l|r|c|c|}
\hline \multicolumn{1}{|c|}{ Porte } & Capacidade instalada & Número de serrarias & (\%) \\
\hline \multirow{2}{*}{ Pequeno } & até $10.000 \mathrm{~m}^{3}$ ao ano & 7.180 & 74,6 \\
\cline { 2 - 4 } & entre $10.000 \mathrm{e} 30.000 \mathrm{~m}^{3}$ ao ano & 2.383 & 24,7 \\
\hline \multirow{2}{*}{ Médio } & entre $30.000 \mathrm{e} 50.000 \mathrm{~m}^{3}$ ao ano & 50 & \\
\cline { 2 - 5 } & entre 50.000 e $100.000 \mathrm{~m}^{3}$ ao ano & 15 & \multirow{2}{*}{0,7} \\
\hline \multirow{2}{*}{ Grande } & entre $100.000 \mathrm{e} 150.000 \mathrm{~m}^{3}$ ao ano & 2 & 100 \\
\cline { 2 - 5 } & acima de $150.000 \mathrm{~m}^{3}$ ao ano & - & \\
\hline \multirow{2}{*}{ Total } & & 9630 & \\
\hline
\end{tabular}

Fonte: STCP, citado por ABIMCI (1998) 
Provavelmente, de $50 \%$ a $60 \%$ das unidades de serrados instaladas no Brasil estão concentradas nas regiões Centro-Oeste e Norte ${ }^{4}$. São, em geral, empresas voltadas para o processamento de madeira de folhosas nobres da Amazônia como mogno, cedro, peroba, canelas entre outras.

Segundo Mercado \& Campagnani (1988), cerca de 33\% da produção de serrados da Amazônia é comercializada dentro da própria região, 55\% vai para outras regiões do país e $12 \%$ vai para o mercado externo. A regra geral é de que as serrarias de pequeno porte atendam ao mercado local, enquanto as produções das serrarias de médio e grande porte são voltadas para os mercados nacional e externo.

O mercado local absorve a madeira de menor valor e qualidade inferior àquela comercializada em níveis nacional e internacional. Sobre esse aspecto, o mercado local é importante não só para as serrarias de pequeno porte, como também para as de médio e grande porte, que nele comercializam sua produção sem qualidade para exportação.

Mercado \& Campagnani (1988) observam que o suprimento da indústria madeireira está atrelado à sazonalidade da exploração de toras, o que requer a estocagem de matéria-prima na época seca, de modo a suprir a demanda ao longo do ano. Somente as empresas bem estruturadas o fazem, enquanto as outras, em grande parte empresas pequenas, decrescem ou até mesmo param a produção durante a época das chuvas.

Os estados do Pará e Rondônia geravam, nos anos 80 , cerca de $97 \%$ da produção de serrados da Amazônia. Angelo (1998) observa, em anos recentes, que a produção de serrados nos estados do Maranhão, Goiás e Mato Grosso tem mostrado comportamento estável, ao passo que aumentos de produção são observados nos estados

\footnotetext{
${ }^{4}$ O Banco Nacional de Desenvolvimento Econômico e Social - BNDES (1995) observa a discrepância entre os números apurados em fontes diversas usadas naquele estudo, o que mostra a dificuldade de se analisar a indústria brasileira de produtos florestais, que é bastante pulverizada e que tem uma parte de suas atividades operando de modo informal.
} 
do Pará e Rondônia. Isto se associa à disponibilidade de matéria-prima. Segundo este autor,

"A indústria madeireira na região está associada à oferta abundante de madeira. Com as dificuldades cada vez maiores de se conseguir matéria-prima florestal, muitas indústrias estão deixando de operar ou migrando para novas fronteiras, caracterizando o perfil extrativista de um percentual expressivo deste setor". (Angelo, 1998, p.12)

Cabe observar que a escassez de matéria-prima se faz presente em várias regiões da Amazônia apontando, a exemplo do que ocorreu no sul do País, mudanças na estrutura de produção naquela região.

Até a década de 70, conforme Angelo (1998), 80\% da matéria-prima empregada na produção de serrados tinha como origem as florestas de várzea ${ }^{5}$. A facilidade de acesso à região, a presença de espécies de grande diâmetro, altura elevada e grande valor comercial levaram à exploração predatória e ao empobrecimento dessa vegetação. Este cenário e a abertura de estradas na região Amazônica colaboraram para a exploração das florestas de terra-firme.

Começa então a ocorrer uma pequena mudança na estrutura de produção da Amazônia, uma vez que a exploração florestal na várzea é diferente da exploração na floresta de terra-firme. Em grande parte, a exploração na várzea é realizada manualmente pelos próprios moradores da região. As árvores são derrubadas, destopadas, traçadas e deixadas na mata para perder umidade, sendo então vendidas a

${ }^{5}$ A floresta Amazônica, em termos de cobertura vegetal, apresenta dois tipos de florestas distintos, a floresta de várzea e a floresta de terra-firme. A floresta de várzea está localizada ao longo dos rios amazônicos, sendo regularmente inundada. Esta vegetação é adaptada a grande variação do nível de água, sendo beneficiada pela renovação regular do solo durante as enchentes. Seu sub-bosque é limpo e aberto.

Angelo (1998) observa que, embora bastante heterogênea em termos de espécies, a floresta de várzea se mostra mais homogênea, em termos de produto, do que a floresta de terra-firme, encontrando-se uma maior concentração de uma mesma espécie por hectare na primeira. A floresta de terra-firme, por outro lado, é característica de áreas altas que não sofrem inundação, sendo marcada pela grande heterogeneidade de espécies, podendo-se encontrar até 300 espécies arbóreas diferentes em um hectare.

Segundo Pandolfo, citado por Angelo (1998), estima-se que a floresta de várzea tenha uma área de 18 a 20 milhões de hectares, enquanto a floresta de terra-firme cubra 253 milhões de hectares, correspondendo, essas duas florestas, a cerca de 15 bilhões de metros cúbicos de madeira em condições de exploração. 
intermediários que as revendem às empresas madeireiras. $\mathrm{O}$ transporte, em geral, ocorre por via fluvial.

Com relação a floresta de terra-firme, de acordo com Mercado \& Campagnani (1988), a exploração ocorre geralmente na época da seca, podendo, entretanto, ser realizada na época das chuvas, por empresas de grande poder econômico. As árvores são tombadas, destopadas, traçadas e carregadas para serem transportadas, por via fluvial ou rodoviária, até as serrarias.

Segundo Angelo (1998), na floresta de terra-firme a exploração ocorre tanto de forma seletiva, baseada no corte de espécies de maior valor comercial, quanto de forma planejada sob o sistema de manejo sustentado ${ }^{6}$, tornando a exploração melhor controlada. Nessas condições, o rendimento em volume de madeira explorada varia, em média, entre 10 e $60 \mathrm{~m}^{3} /$ ha contra uma média de 10 a $40 \mathrm{~m} / \mathrm{ha}$ na floresta de várzea.

Ainda, de acordo com mesmo autor,

"Com os esforços dos diversos setores do meio florestal em agrupar as espécies de características tecnológicas similares, dando, assim, um maior aproveitamento às espécies exploradas pouco conhecidas, o rendimento do volume de madeira por hectare deverá aumentar, diminuindo os custos de exploração e contribuindo para viabilizar os planos de manejo sustentados". (Angelo, 1998, p.25)

Cabe observar, no entanto, que o grau de exploração florestal sustentável na Amazônia ainda é baixo e, quando empregada, concentra-se nos projetos de pesquisa e em um pequeno número de empresas.

Conforme Veríssimo et al. (1992), na região de Paragominas, no Pará, dada a falta de manejo sustentável e devido ao emprego de técnicas rudimentares em grande parte das explorações florestais, para cada $1 \mathrm{~m}^{3}$ de madeira extraída, quase $2 \mathrm{~m}^{3}$ de madeira são desperdiçados, em função, principalmente, da queda de árvores com valor comercial desconhecido.

\footnotetext{
${ }^{6}$ A realização dos planos de manejos sustentados tornou-se obrigatoriedade imposta pelo governo federal,
} 
Além dos esforços para os planos de manejo sustentado, algumas empresas vêm empregando técnicas de reflorestamento baseadas em espécies potenciais para a região, como a teca (Tectona grandis), o mogno (Swietenia macrophylla) e o pinho cubano (Schizolobium amazonicum).

Outro fenômeno observado, no que tange a mudança na estrutura de produção da Amazônia, diz respeito ao processo de verticalização e agregação de valor ao produto serrado. Angelo (1998), baseado em estudo da Federação das Indústrias de Rondônia ${ }^{7}$, observa que embora a atividade de desdobramento da madeira represente cerca de $50 \%$ do total das empresas que processam madeira, esta atividade sofreu queda de $31,5 \%$, no período de 1987 a 1994 , com redução de 245 empresas. No mesmo período, a produção de artigos diversos de madeira cresceu $565 \%$ e as atividades de produção de chapas, placas e móveis em geral, cerca de $385 \%$.

Cabe observar que essa tendência não representa um fenômeno restrito a Rondônia. A agregação de valor ao produto vem sendo observada em grande parte da indústria produtora de serrados no Brasil, particularmente naquelas de médio e grande porte. Conforme ABIMCI (1999), essa tendência teve início no final da década de $80 \mathrm{e}$ começo dos anos 90, em função da oportunidade de negócios proporcionada pelo mercado externo e pelo desenvolvimento do setor moveleiro.

É importante, ainda, observar que os produtos de maior grau de processamento como, por exemplo, blocks, blanks, fence, molduras, EGP (Edge Glued Panel) são menos seletivos em relação às espécies utilizadas e suas produções ajustam-se perfeitamente ao uso de árvores com dimensões menores. Em sua produção são gerados menos resíduos, o que causa menos controvérsia do ponto de vista ambiental. Segundo Gresham (1995), o custo de elaboração desses produtos pode ser altamente competitivo quando as unidades processadoras se localizam próximas às fontes de matérias-primas. 
Inicialmente, a elaboração dos produtos de maior valor agregado estava essencialmente baseada na madeira de pinus. Contudo, nos últimos anos, o eucalipto vem se mostrando uma espécie com grande potencial para esses produtos ${ }^{8}$. Em função da disponibilidade de matéria-prima, os estados do Paraná e Santa Catarina se destacam como principais produtores dos produtos acima mencionados.

Em decorrência da disponibilidade de florestas plantadas e da demanda criada pela indústria moveleira, em anos recentes, empresas da Região Norte vêm instalando fábricas nas regiões Sul e Sudeste, processo semelhante ao observado nas décadas de 70 e 80 , quando muitas fábricas da Região Sul instalaram unidades de produção nos estados do Pará, Maranhão, Mato Grosso e Rondônia (BNDES, 1995).

Essa nova fase na industrialização de madeira serrada nas regiões Sudeste e Sul se baseia no uso do eucalipto e pinus.

A produção de madeira serrada de pinus é bastante pulverizada. Segundo Silva (1996), em 1996 existiam cerca de 48 empresas produtoras de serrados de pinus no mercado nacional. As cinco maiores empresas, a saber, a Battistella, Pisa e Imaribo, com capacidade produtiva de $84 \mathrm{mil} \mathrm{m}^{3} /$ ano cada uma; a Duratex, com $78 \mathrm{mil}$ $\mathrm{m}^{3} /$ ano e a Berneck, com capacidade de produção de $72 \mathrm{mil} \mathrm{m}^{3} / \mathrm{ano}$; foram responsáveis, naquele ano, por cerca de $23 \%$ da produção total de madeira serrada de pinus.

Entre as empresas de maior porte na produção de madeira serrada de eucalipto podem-se citar, ainda, a FLOSUL (em torno de $24 \mathrm{mil} \mathrm{m}^{3} / \mathrm{ano}$ ); a Wood Reflorestamento (7,2 mil $\left.\mathrm{m}^{3 / a n o}\right)$; a CAF Santa Bárbara Ltda. (24 mil $\left.\mathrm{m}^{3} / \mathrm{ano}\right)$ e a Duratex S.A. (26,4 mil mªno); e a Aracruz (75 mil mªno)

Cabe mencionar que as maiores oportunidades para o avanço do Brasil no mercado mundial estão na produção de madeira serrada proveniente de eucalipto, por

\footnotetext{
${ }^{8}$ É importante observar que, até o começo dos anos 90, as plantações de árvores com fins madeireiros nas regiões Sul e Sudeste eram basicamente de coníferas (como o pinus) e eucalipto. Porém, há outras espécies que estão sendo introduzidas, como mogno, teca, cedro, virola, entre outras, principalmente na Região Centro-Oeste.
} 
parte das empresas fabricantes de celulose. Assim, a integração observada no exterior entre as indústrias de produtos de madeira e as de celulose e papel representa uma oportunidade natural no sentido de aproveitar as sinergias potencialmente existentes entre esses setores ${ }^{9}$.

No Gráfico $l$ está a evolução da produção brasileira de madeira serrada de coníferas e não coníferas no período de 1961 a 1999. Como se pode observar, a produção total de serrados passou de 6,4 milhões de $\mathrm{m}^{3}$ no começo da década de 60 , para cerca de 18,6 milhões de $\mathrm{m}^{3}$ no ano de 1999 , crescendo, em média, 3,9\% ao ano, contra apenas $0,5 \%$ da média mundial ${ }^{10}$. No entanto, o Brasil ainda detém parcela pequena da produção mundial de serrados. Em 1999, o Brasil respondeu por 4,3\% da produção mundial de serrados.

Gráfico 1 Evolução da produção brasileira de madeira serrada no período de 1961 a 1999

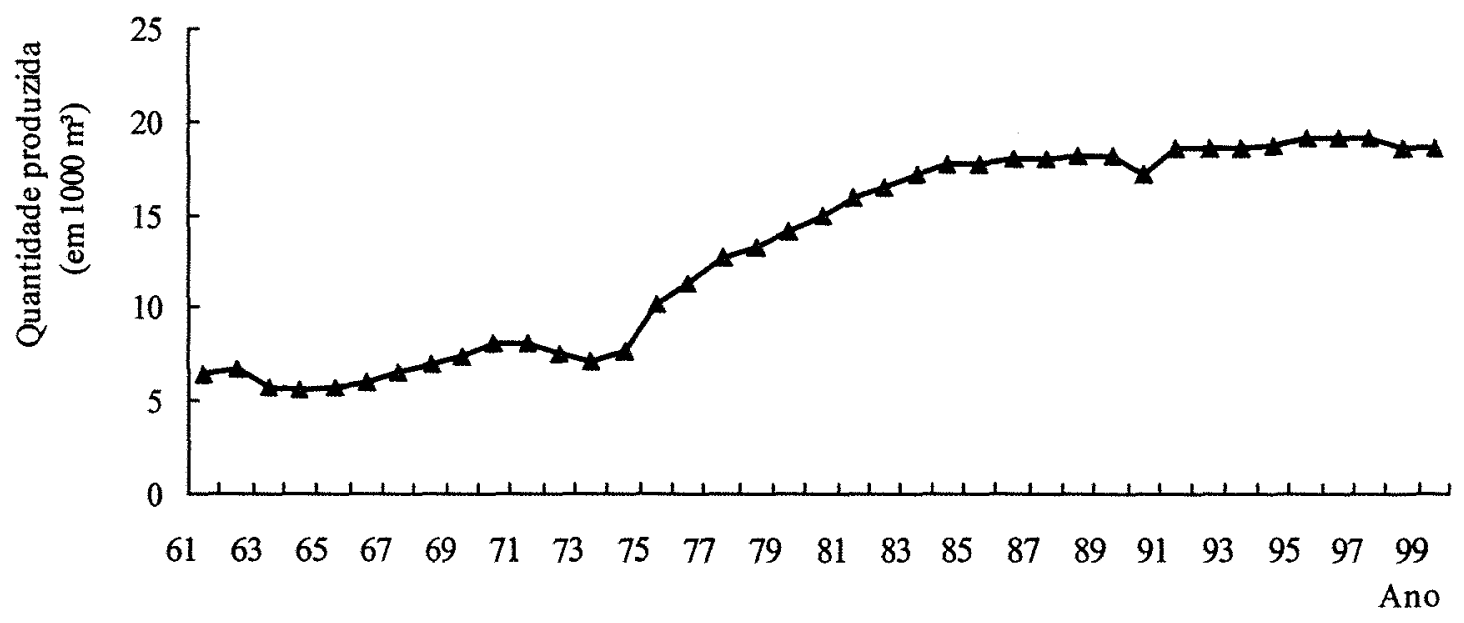

Fonte: home page da FAO (www.fao.org)

\footnotetext{
${ }^{9}$ É indicativo, nesse sentido, os atuais investimentos da Aracruz Celulose na área de madeira sólida. Conforme consta em Hilgemberg (2000), a Aracruz Produtos de Madeira S.A. é um investimento de US $\$ 50$ milhões e capacidade produtiva de $75 \mathrm{mil} \mathrm{m}^{3} / \mathrm{ano}$, com cerca de $45 \%$ da sua produção destinada ao mercado externo.

${ }^{10}$ A taxa média de crescimento foi calculada pelo antilogaritmo $(\delta)-1$, onde $\delta$ é o coeficiente da função $\log \mathrm{X}=\alpha+\delta \mathrm{Y}$ sendo $\mathrm{X}$ é o quantum exportado e $\mathrm{Y}$ a variável tendência, medida na unidade da série, neste caso em anos.
} 
Nota-se no Gráfico 1 a existência de três fases na evolução da produção brasileira de madeira serrada. De 1963 a 1971 esta produção aumentou, ainda baseada na exploração das remanescentes florestas do sul. No período de 1974 a 1989 , houve grande expansão na produção de serrados, o que foi possível devido a expansão da indústria na Região Norte. A estagnação da produção na década de 90 ocorreu como resultado da expansão da indústria baseada em reflorestamentos nas regiões Sudeste e Sul e do declínio na produção da Região Norte.

O Gráfico 2 situa o Brasil entre os principais países produtores de madeira serrada. Como se observa os três maiores produtores detêm mais de $50 \%$ da produção mundial de madeira serrada. Os Estados Unidos é o maior produtor, com $28 \%$ da produção mundial, secundado do Canadá com 16\% e da China com $8 \%$.

\section{Gráfico 2 Principais países produtores de madeira serrada em 1999}

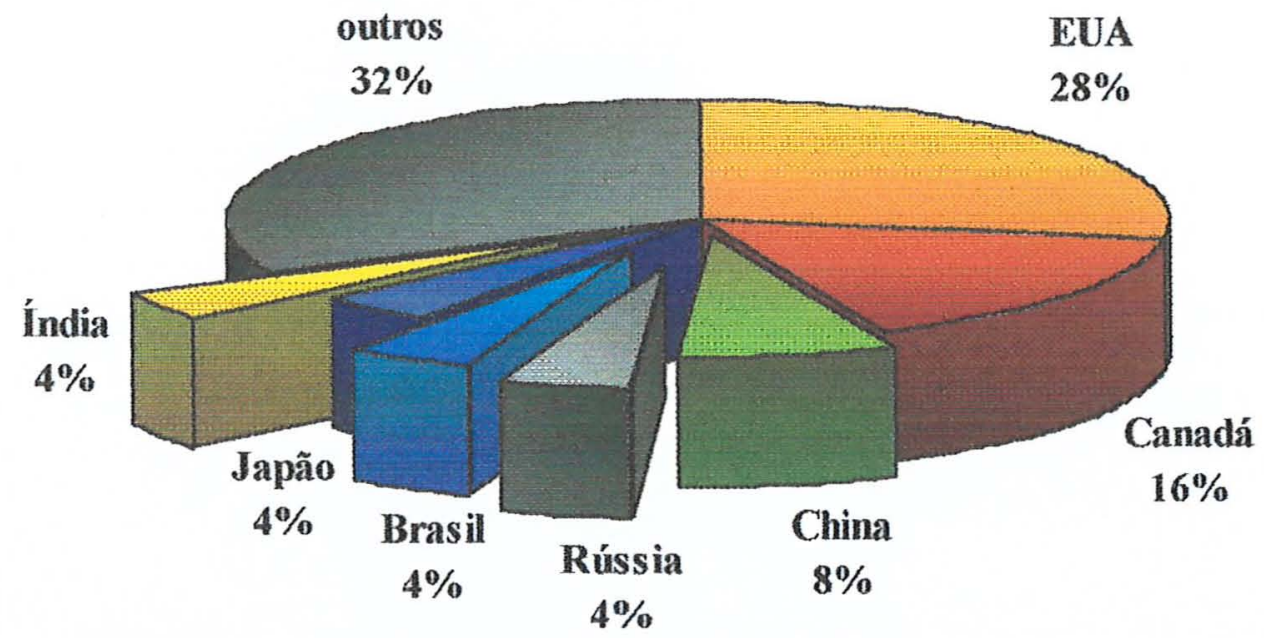

Fonte: home page da FAO (www.fao.org)

O Brasil aparece entre os maiores produtores dos dois tipos de madeira serrada (de coníferas e não coníferas), com maior participação na produção de não 
coníferas, cerca de $9,2 \%$ da produção mundial, vindo logo depois dos Estados Unidos (com $30,2 \%$ ) e da Índia (com $13,8 \%$ ).

Entretanto, cabe observar que o desempenho da produção de madeira serrada no Brasil (e, consequentemente, o desempenho das exportações) pode estar comprometido nos próximos anos, o que se deve, sobretudo, a duas questões, as quais comprometem não só essa indústria, mas grande parte da indústria de produtos sólidos de madeira.

A primeira diz respeito à evolução das áreas plantadas com espécies florestais de rápido crescimento que, atualmente, sustentam cerca de $45 \%$ da produção de serrados. O plantio de florestas homogêneas se desenvolveu intensamente até meados da década de 80 graças aos incentivos fiscais ao reflorestamento que, após intensas e incessantes modificações na legislação, acabaram em 1988 (sendo os últimos projetos aprovados em 1986). Na década de 90, o plantio anual de florestas tem sido menor do que nos anos onde vigoraram os incentivos fiscais.

Ao contrário da decisão brasileira, inúmeros países da América do Sul, América do Norte, Europa, África, Ásia e Oceania continuam a conceder incentivos e outros mecanismos de estímulo e favorecimento à implantação de florestas. Até 2000, entre os países do Mercosul, apenas o Brasil não possuía uma política ampla de incentivos ao reflorestamento ${ }^{11}$. Esses países possuem políticas agressivas para o setor florestal, o que tem levado a um aumento substancial da área reflorestada e atraído investidores de vários países àquela região.

\section{Conforme Zugman (1998, p.54)}

"Implantar novas florestas na Argentina, Uruguai e Paraguai, devido a políticas de incentivos vigentes, custa $50 \%$ menos que no Brasil. Situação similar de incentivos existe também no Chile. Em florestas, onde ciclos de 20 ou mais anos são esperados, o impacto de subsídios

\footnotetext{
${ }^{11}$ O Plano Nacional de Florestas (PNF), aprovado em setembro de 2000, procura contemplar incentivos ao plantio de florestas.
} 
ou incentivos ao nivel de reduzir em até $50 \%$ os investimentos iniciais, é extremamente forte".

Outros exemplos de estímulo a exploração florestal ocorrem no Canadá, Portugal e Malásia. No Canadá, o governo concede a exploração de áreas florestais públicas ( $99 \%$ das florestas do país) através de licenças, subsidiando o custo de produção da madeira nessas áreas. Segundo Zugman (1998), esse subsídio é tão evidente que fez com que os Estados Unidos impusessem cotas de importação sobre as madeiras do Canadá, mesmo havendo entre esses dois países um acordo de livre comércio. Em Portugal, o governo, em parceria com o Banco Mundial, desenvolveu um projeto de incentivo ao reflorestamento em todo o país. Como resultado, desde meados dos anos 90 , vem ocorrendo um aumento da capacidade produtiva em cerca de $90 \%$. A Malásia, além dos programas básicos de formação de novas florestas, possui um Plano Mestre Industrial para a indústria de base florestal que, de acordo com Garipp e Oliveira (1997), procura estimular a agregação de valor aos produtos finais e, sobretudo, vem buscando novos mercados para ampliar seus empreendimentos, como as florestas da América do Sul.

Estas experiências internacionais têm servido de exemplo às empresas que necessitam de madeira para pressionar por formas de incentivo que permitam acelerar o ritmo de reflorestamento. Parcialmente, essas pressões foram contempladas no Plano Nacional de Florestas, lançado pelo Ministério de Meio Ambiente em setembro de 2000.

A segunda questão se refere à produção de madeira serrada de não coníferas, bastante alicerçada nas florestas nativas da Amazônia, o que até o momento vem ignorando as mudanças comportamentais do mercado internacional na direção da sustentabilidade dos recursos naturais. A exploração seletiva predominante na Amazônia, o que se traduz no aproveitamento de um número reduzido de espécies, 
contribui para aumentar o ritmo dos desbastes e envolve perdas significativas de recursos florestais ${ }^{12}$; o que reduz a "competitividade ambiental" das espécies tropicais.

A este respeito, de acordo com Macedo et al. (1997, p.162),

“(...) $54 \%$ das exportações brasileiras de madeira serrada, em 1996, tiveram como origem a região amazônica, utilizando, em larga escala, madeiras nativas (o Estado do Pará, sozinho, respondeu por $51 \%$ do valor da madeira serrada exportada pelo Brasil em 1996). Os custos ambientais incorridos têm sido elevados, sendo necessária a incorporação de novas tecnologias que permitam a exploração da floresta amazônica de forma mais sustentada".

É importante, ainda, mencionar que as condições precárias de produção (como maquinário obsoleto, ausência de secagem e tratamentos preservativos e problemas de oferta contínua de matéria-prima), sobretudo na Amazônia, se refletem na qualidade, má apresentação do produto, desrespeito a prazos, volumes $\mathrm{e}$ especificações contratualmente estipulados.

Merece menção também a redução na oferta de madeira serrada em nível mundial, o que se deve, sobretudo, às crescentes pressões ambientalistas sobre o corte indiscriminado de florestas. O governo da Malásia (e também da Indonésia e de outros países asiáticos), por exemplo, desde 1993 vem impondo crescentes restrições ao corte de florestas tropicais. As exportações de madeira serrada e em tora, nestes países, enfrentam inúmeras restrições e proibições. Os produtos de maior valor agregado são privilegiados. O Canadá, por sua vez, já sofre com os problemas de escassez de recursos florestais de alta qualidade e com pressões ambientalistas para que as florestas públicas não sejam exploradas para fins industriais. Os produtores americanos também vêm passando por dificuldades no abastecimento de madeira devido a correntes contrárias ao corte de florestas em áreas governamentais da costa oeste.

\footnotetext{
${ }^{12}$ Segundo Angelo (1998), nessas condições de exploração, o rendimento do volume de madeira por hectare é bastante variável, podendo atingir de 0,3 a $70 \mathrm{~m}^{3}$, dependendo da ocorrência de espécies de valor comercial na área explorada .
} 


\subsection{Evolução das exportações brasileiras de serrados de madeira}

Segundo dados da FAO, o comércio internacional de madeira serrada movimentou, em 1999, cerca de 120 milhões de $\mathrm{m}^{3}$, o que correspondeu a cerca de $28 \%$ da produção mundial, contra apenas $12 \%$ no ano de 1961 , crescendo, em média, 2,6\% ao ano nesse período. A comercialização de madeira serrada de coníferas representa cerca de $85 \%$ desse mercado. Contudo, os serrados de não coniferas vêm ganhando espaço e suas exportações cresceram, em média, 3,6\% ao ano no mesmo período. Além do avanço na comercialização dos produtos de não coníferas, merece menção a valorização destes produtos, conforme mostra a Tabela 1.

\section{Tabela 1}

Valor unitário das exportações mundiais de madeira serrada em anos selecionados $\left(\mathbf{e m} \mathrm{US} \$ / \mathbf{m}^{3}\right)$

\begin{tabular}{lccccc}
\hline Espécie & 1980 & 1985 & 1990 & 1998 & $\begin{array}{c}\text { Taxa anual de } \\
\text { crescimento } \\
(\mathbf{1 9 8 0} \text { a 1998) }\end{array}$ \\
\hline Coníferas & 138 & 105 & 172 & 175 & 3,1 \\
Não Coníferas & 141 & 193 & 303 & 325 & 4,0 \\
\hline
\end{tabular}

Fonte: home page FAO (www.fao.org)

* Calculada pela autora, utilizando o antilogaritmo $(\delta)-1$, onde $\delta$ é o coeficiente da função $\log X=\alpha+$ $\delta \mathrm{Y}$ sendo $\mathrm{X}$ é o quantum exportado e $\mathrm{Y}$ a variável tendência, medida na unidade da série, neste caso em anos.

A Tabela 2 traz os maiores exportadores mundiais de madeira serrada em anos selecionados. Em 1999, o Canadá foi responsável por 41,4\% das exportações mundiais de madeira serrada (cerca de $47,5 \%$ quando consideradas apenas as transações envolvendo coníferas), seguido da Suécia com 9,2\%, e da Finlândia com 6,9\%. 
Tabela 2

Maiores exportadores mundiais de madeira serrada em anos selecionados (em mil $\left.\mathbf{m}^{3}\right)$

\begin{tabular}{lccccc}
\hline Países & $\mathbf{1 9 8 0}$ & $\mathbf{1 9 8 5}$ & $\mathbf{1 9 9 0}$ & $\mathbf{1 9 9 9} \begin{array}{c}\text { Taxa anual de } \\
\text { crescimento } \\
(\mathbf{1 9 8 0} \text { a 1999) }\end{array}$ \\
\hline Canadá & 29.326 & 39.004 & 37.937 & 49.675 & 2,9 \\
\hline Suécia & 5.915 & 7.898 & 6.252 & 11.062 & 3,1 \\
\hline Finlândia & 6.939 & 4.898 & 4.176 & 8.292 & 2,4 \\
\hline Estados Unidos & 5.834 & 4.534 & 9.082 & 6.015 & 1,4 \\
\hline Rússia & & & & 6.433 & \\
\hline Malásia & 3.302 & 2.830 & 5.332 & 2.837 & 1,0 \\
\hline Brasil & $\mathbf{8 0 9}$ & $\mathbf{4 9 3}$ & $\mathbf{5 0 9}$ & $\mathbf{1 . 9 4 4}$ & $\mathbf{6 , 3}$ \\
\hline Outros & 27.503 & 26.382 & 25.715 & 33.595 & \\
\hline Total & 79.628 & 86.039 & 89.003 & 119.853 & 2,4 \\
\hline
\end{tabular}

Fonte: home page FAO (www.fao.org)

* Calculada pela autora, utilizando o antilogaritmo $(\delta)$ - 1 , onde $\delta$ é o coeficiente da função $\log X=\alpha+$ $\delta \mathrm{Y}$ sendo $\mathrm{X}$ é o quantum exportado e $\mathrm{Y}$ a variável tendência, medida na unidade da série, neste caso em anos.

A participação brasileira no comércio internacional de serrados é bastante modesta, posto que, no ano de 1999, contribui com apenas $1,6 \%$ das exportações mundiais. Cabe observar, no entanto, que no período de 1980 a 1999 o Brasil obteve a mais alta taxa de crescimento do volume exportado quando comparado aos maiores exportadores, cerca de $6,3 \%$ ao ano, contra apenas $2,4 \%$ da média mundial. Os dados relativos ao período de 1990 a 1999 revelam uma taxa média de crescimento das exportações brasileiras de madeira serrada ainda maior, cerca de $15,4 \%$ ao ano. Este excelente crescimento das exportações está associado às mudanças ocorridas no volume e na composição da produção, as quais foram analisadas no item anterior. 


\section{Gráfico 3 Evolução das exportações brasileiras de madeira serrada no período de 1961 a 1999}

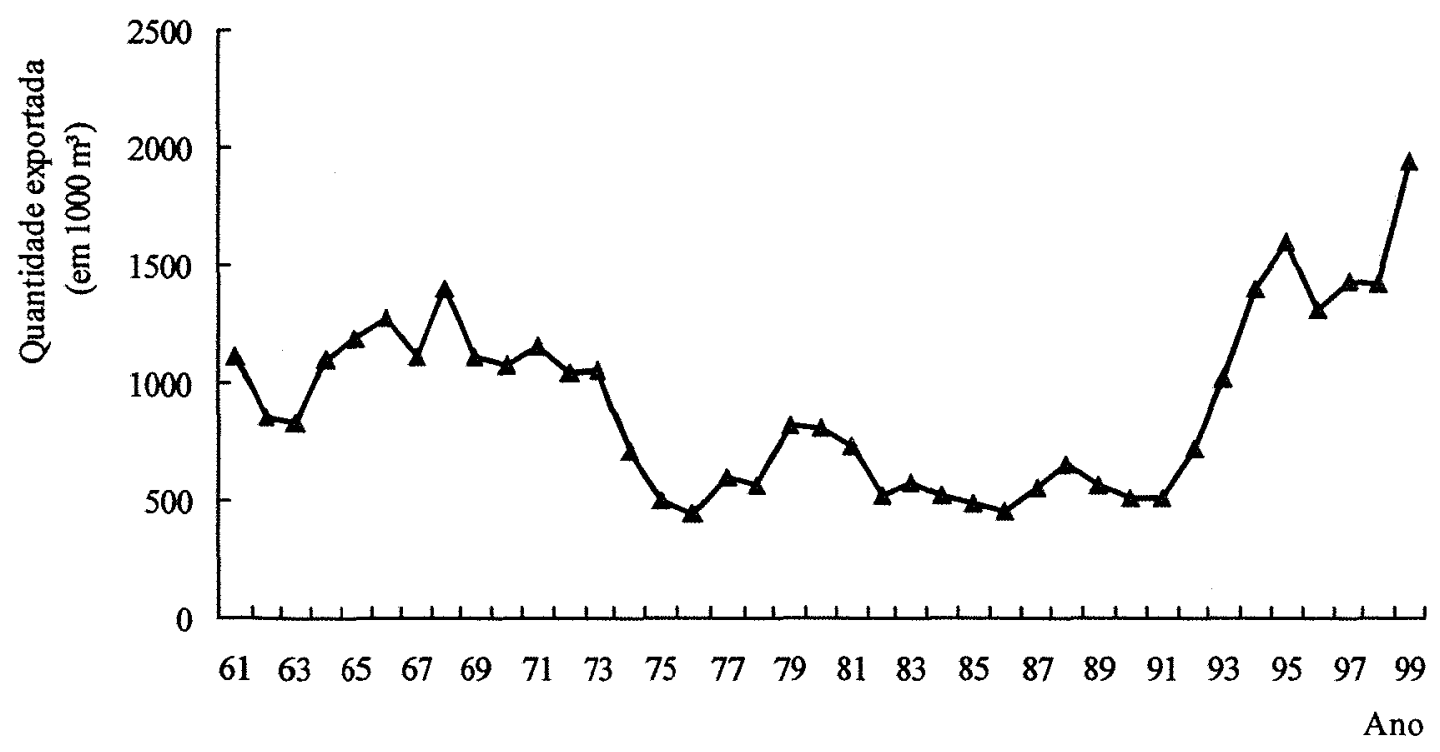

Fonte: home page da FAO (www.fao.org)

O bom desempenho das exportações de madeira serrada, na década de 60, deveu-se ao "boom" da exploração da Araucária angustifólia no sul do País. Como observam Ribeiro \& Machado (1982), durante a década de 60 e alguns anos da década de 70, a participação dos produtos sólidos de madeira, no comércio externo, baseava-se praticamente na exportação de toras e de madeira serrada, sendo que, no caso específico da madeira serrada, as espécies comercializadas não ultrapassavam seis, com destaque para a Araucária angustifolia, exportada em grandes quantidades.

Com a exaustão das reservas de araucária, o que se observou foi uma acentuada queda das exportações de madeira serrada no começo dos anos 70 . Os produtos serrados de folhosas começaram, na mencionada década, a ganhar maior destaque na pauta de exportação. Contudo, a recessão mundial nos anos 80 implicou um período de fraco desempenho do volume exportado.

A análise desagregada das exportações de madeira serrada (Gráfico 4) revela que a quebra de tendência observada no quantum exportado, no final da década de 
60, deve-se a queda contínua das exportações de serrados de coníferas. No período de

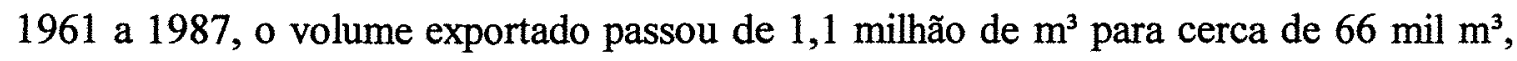
respectivamente, o que representa um decréscimo de $11,7 \%$ ao ano. A partir daí, com a boa aceitação dos serrados de pinus no mercado, há recuperação das exportações, que cresceram, em média, 24,4\% ao ano, no período de 1988 a 1999.

Gráfico 4 Evolução das exportações brasileiras de madeira serrada de coníferas e não coníferas no período de 1961 a 1999

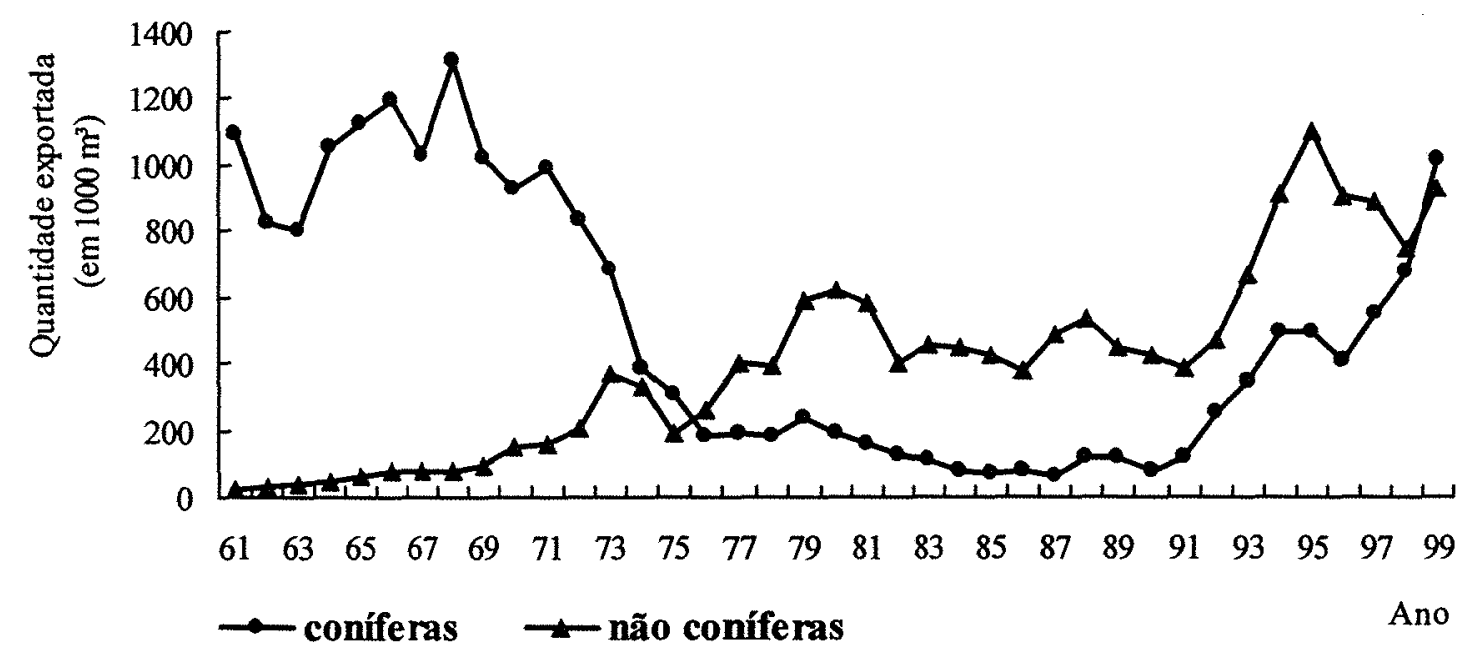

Fonte: home page da FAO (www.fao.org)

As exportações de madeira serrada de não coniferas apresentam tendência crescente ao longo de praticamente todo o período analisado (Gráfico 4), com exceção aos anos 80 quando ocorre estagnação e até mesmo redução do quantum exportado. Atualmente, esses produtos vêm perdendo dinamismo nas exportações, mas ainda representam cerca de $48 \%$ das exportações de madeira serrada.

Em 1965, as exportações brasileiras de serrados representavam 21,1\% da sua produção, apresentado forte desaceleração até 1986, quando estavam em torno de 2,5\%. Em 1999 essas exportações corresponderam a 10,5\% da produção, o que evidencia a existência de um viés pró-mercado doméstico. 
As exportações brasileiras de madeira serrada enfrentam fortes restrições do lado da demanda, tanto no que se refere a composição das espécies demandadas quanto com relação a sua procedência. $O$ mercado externo, tradicional demandante de coníferas, mostra-se cauteloso no consumo de novas espécies, como é o caso de serrados baseados em folhosas da Amazônia.

Segundo Mercado \& Campagnani (1988), das cerca de 400 espécies arbóreas de folhosas comerciáveis ${ }^{13}$, a composição da pauta de exportação se restringe a um seleto grupo de espécies como o mogno, a virola, o jatobá, a imbuia, o cedro, entre outras. Algumas espécies são evitadas devido a características indesejáveis como peso e dureza em excesso ou pouca resistência e durabilidade, enquanto outras são evitadas simplesmente por falta de conhecimento de suas características pelo mercado.

Segundo dados da Secretaria de Comércio Exterior (SECEX), citados por Angelo (1998), observa que, no período de 1980 a 1993, as exportações de madeira serrada se concentraram em duas espécies, o mogno (Swietenia macrophyla) e virola (Virola surinamensis), que responderam por $40,38 \%$ do quantum exportado.

O Gráfico 5 traz os principais países de destino das exportações brasileiras de madeira serrada. Conforme se observa há elevada concentração das vendas para os Estados Unidos, cerca de 31\%, seguido da França com 10\%, da Espanha com $6 \%$, e do Reino Unido e da Argentina, que absorvem cada um 3\% dessa madeira.

\footnotetext{
${ }^{13}$ O Instituto de Pesquisas da Amazônia (INPA) já catalogou mais de 5.000 espécies.
} 
Gráfico 5 Principais países de destino das exportações brasileiras de madeira serrada em 1998

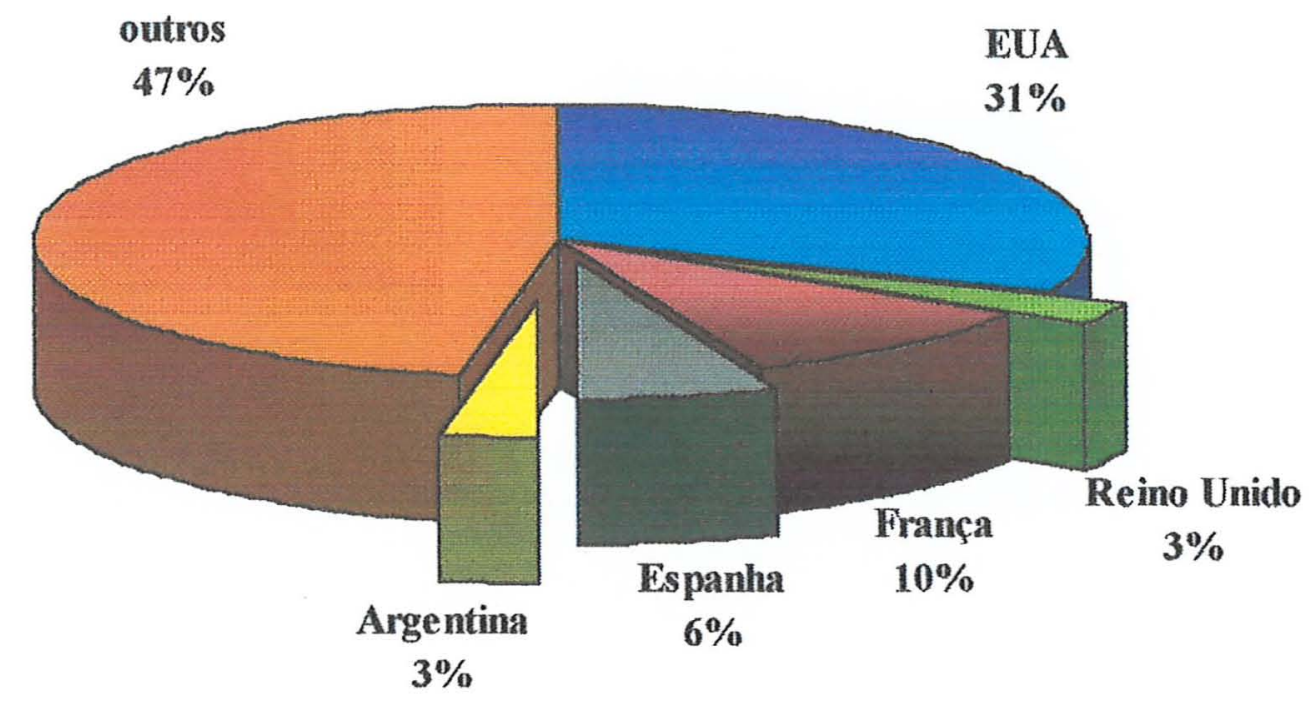

Fonte: home page da FAO (www.fao.org)

Cabe comentar que esses países são extremamente conservadores com relação ao consumo de produtos serrados oriundos de novas espécies. O mercado britânico, o maior para madeiras tropicais brasileiras dentro da Europa Ocidental, por exemplo, concentra $90 \%$ de suas importações em uma única espécie, o mogno.

Mercado \& Campagnani (1988), baseados em estudo da Universidade Federal Rural do Rio de Janeiro ${ }^{14}$, sobre os consumidores norte-americanos, observam que $30 \%$ dos importadores diretos e $75 \%$ dos importadores indiretos ${ }^{15}$ não demonstram interesse em produtos serrados oriundos de novas espécies brasileiras, ao passo que os usuários finais não tem conhecimento nem interesse em outras espécies que não aquelas já utilizadas.

\footnotetext{
${ }^{14}$ Universidade Federal Rural do Rio de Janeiro; Instituto Brasileiro de Desenvolvimento Florestal. Contribuição do mercado madeireiro no desenvolvimento regional. Rondônia; Rio de Janeiro: UFRRJ/IBDF, 1985. $2 \mathrm{v}$.

${ }^{15}$ Quanto ao método de aquisição da madeira foram distintos dois grupos de importadores: os que adquirem a madeira amazônica diretamente do Brasil e aqueles que a adquirem de intermediários
} 
Segundo os mesmos autores,

"(...) os fatores mais limitantes na aceitação de novas espécies amazônicas brasileiras no mercado norte-americano são os altos custos, a falta de informação e marketing inadequado, disponibilidade de espécies domésticas mais baratas e propriedades mecânicas das madeiras brasileiras inadequadas para usos industriais (duras, pesadas, densas)". (Mercado \& Campagnani, 1988, p.61)

Se as questões de gosto e preferência dos consumidores explicam a dificuldade de introdução de novas espécies no mercado externo e podem, até certo ponto, explicar o mau desempenho das exportações nas décadas de 70 e 80, o aumento sustentado das exportações brasileiras de madeira serrada nos anos 90 encontra respaldo em outros fenômenos.

Esse comportamento esteve, de certo modo, relacionado às tendências do comércio mundial, que também mostrou bom desempenho no período recente. As exportações mundiais cresceram, em média, 3,4\% ao ano entre 1990 e 1999. Assim, pode-se dizer que uma parte do crescimento das exportações brasileiras de madeira serrada na década de 90 se deve a um aumento global na demanda externa.

Outro aspecto se refere à queda na produção dos grandes fornecedores de serrados de coníferas e não coníferas no período entre 1990 e 1999, com taxas médias de decréscimo de $1 \%$ e 2,1\% ao ano, respectivamente, conforme mostra o Gráfico 6. 
Gráfico 6 Evolução da produção mundial de madeira serrada de coníferas e não coníferas no período de 1961 a 1999

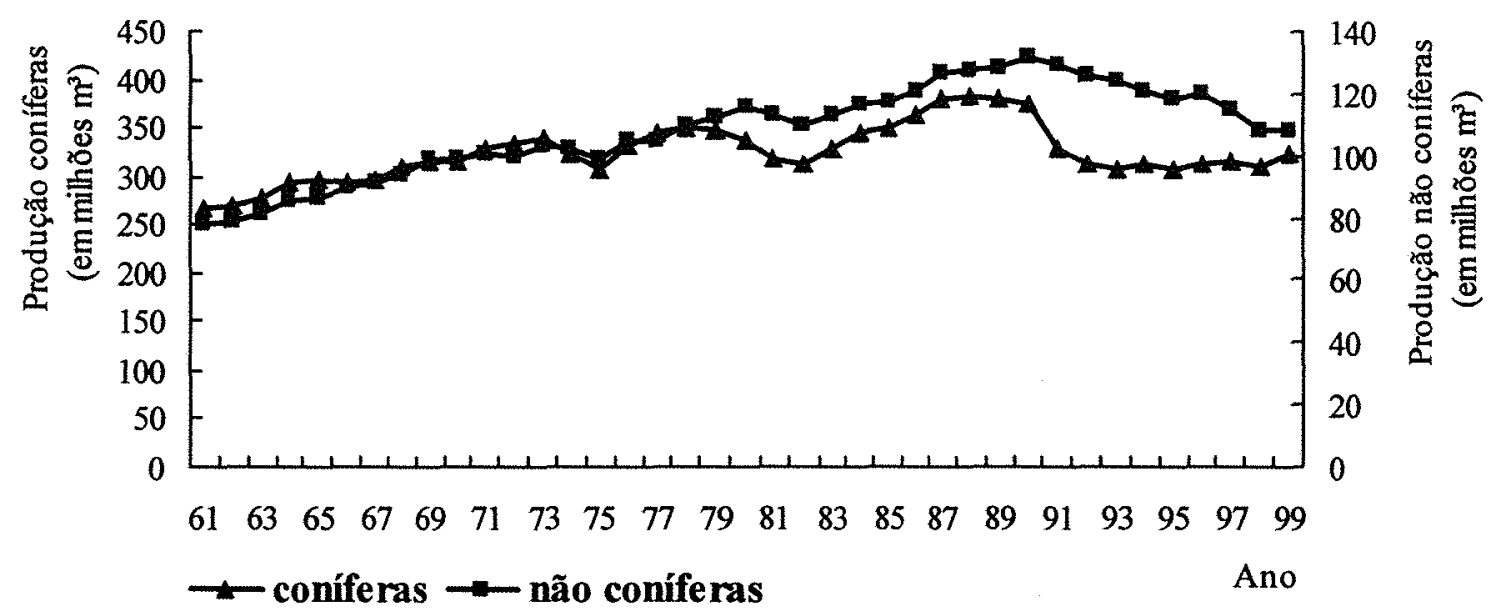

Fonte: home page da FAO (www.fao.org)

Convém observar que o bom desempenho das exportações brasileiras de madeira serrada, no período pós abertura comercial, está baseado em produtos oriundos de reflorestamentos (pinus e eucalipto) e nos serrados de madeiras tropicais, $o$ que representa um movimento no sentido da exploração das vantagens comparativas do país. Como observam Cavalcanti \& Ribeiro (1998), boa parte da literatura sobre comércio propõe que uma das conseqüências da liberalização comercial seria o redirecionamento do comércio no sentido das vantagens comparativas de cada país.

Valverde et al. (1997), utilizando a análise econômica de equilíbrio geral, aplicada por meio do modelo GTAP (Global Trade Analyses Project), analisaram os impactos da liberalização do comércio internacional nos produtos florestais da economia brasileira e concluíram, entre outras coisas, que com a liberalização comercial ocorrem, no Brasil, aumentos na quantidade produzida e exportada de commodities florestais. Segundo os autores, o Brasil vai se firmando como uma nação altamente competitiva neste setor, em virtude, principalmente, do seu potencial edafoclimático e do baixo custo da produção florestal. 
No entanto, a competitividade brasileira não é idêntica para todos os produtos. No caso específico dos produtos serrados, por exemplo, a competitividade brasileira ainda é bastante frágil. Segundo estudo de Macedo et al. (1997), o desempenho das exportações de serrados de não coníferas, quando se considera o market share, revela uma posição vulnerável nos mercados relevantes em que atua, uma vez que a participação dos produtos brasileiros não tem sido expressiva nos principais mercados importadores. Os produtos brasileiros praticamente não lideram em nenhum desses mercados, o que, segundo os mesmos autores, representa um indicador da fragilidade das vendas externas de madeira serrada .

Merece menção, também, a perda de market share desses produtos na segunda metade da década de 90, após ter havido ganhos na primeira metade (Tabela 3). Talvez isso esteve associado à valorização cambial que ocorreu no Brasil na segunda metade da década de 90, a qual fez os preços em dólar da madeira serrada aumentar (Tabela 1) e, consequentemente, a quantidade exportada diminuir (Gráfico 4). Além disso, a crise asiática e a desvalorização das moedas locais tornaram mais competitivas as exportações dos maiores players no mercado internacional de madeiras tropicais, como a Malásia e a Indonésia. 


\section{Tabela 3}

Market Share nos principais países importadores de madeira serrada brasileira de não coníferas em anos selecionados

(em \%)

\begin{tabular}{lccccc}
\hline Países & 1980 & 1985 & 1990 & 1994 & 1998 \\
\hline França & $1^{(9)}$ & $2^{(6)}$ & $7^{(4)}$ & $46^{(1)}$ & $27^{(1)}$ \\
Estados Unidos & $31^{(1)}$ & $23^{(2)}$ & $8^{(2)}$ & $15^{(2)}$ & $10^{(2)}$ \\
Filipinas & & & & $36^{(2)}$ & $15^{(2)}$ \\
Espanha & $7^{(4)}$ & $5^{(4)}$ & $7^{(5)}$ & $13^{(4)}$ & $8^{(6)}$ \\
Reino Unido & $10^{(3)}$ & $12^{(3)}$ & $9^{(3)}$ & $5^{(4)}$ & $3^{(12)}$ \\
\hline
\end{tabular}

Fonte: Macedo et al. (1997); home page FAO (www.fao.org)

Nota: Os números entre parênteses se referem a colocação do Brasil entre os principais países fornecedores do mercado importador.

Macedo et al. (1997) comparam as participações do Brasil e da Malásia (país líder no mercado de madeira serrada de não coníferas) em cada um dos principais países importadores. Os autores constatam que a Malásia é um fornecedor com elevado market share nos mercados com maiores taxas de crescimento do consumo (como Tailândia, Japão e Coréia), enquanto o Brasil desfruta de uma posição secundária no mercado americano, cujo desempenho das importações não tem sido dos mais expressivos.

Outro fator condicionante da competitividade do Brasil no mercado internacional de produtos sólidos de madeira é a questão ambiental. Os problemas ambientais relacionados à indústria de serrados envolvem questões como as perdas e desperdícios de recursos florestais no processo produtivo e o tratamento químico utilizado para a preservação da madeira, além do desmatamento.

Frente à evidência crescente da temática ambiental, os países exportadores de madeira passaram, cada vez mais, a enfrentar embargos e restrições ao livre comércio por parte; sobretudo, das organizações não governamentais e dós governos. É importante mencionar que essas medidas, de forma geral, têm afetado mals 
as madeiras tropicais do que as temperadas. O Quadro 2 evidencia algumas restrições impostas pelos países importadores de madeira serrada.

\section{Quadro 2}

Principais embargos e restrições ao comércio de madeiras tropicais

\begin{tabular}{|l|l|l|}
\hline Ano & Origem & Medida \\
\hline 1987 & Reino Unido & $\begin{array}{l}\text { "Amigos da Terra" clamam para um boicote das } \\
\text { madeiras tropicais. }\end{array}$ \\
\hline 1988 & Alemanha & $\begin{array}{l}\text { 200 cidades (City Councils) decidem não mais usar } \\
\text { madeiras tropicais. }\end{array}$ \\
\hline 1988 & Parlamento Europeu & $\begin{array}{l}\text { Anuncia decisão de todos os membros de banir as } \\
\text { importações de madeiras de Sarawak (Malásia) }\end{array}$ \\
\hline 1989 & Alemanha & $\begin{array}{l}\text { O Ministério da Habitação anuncia decisão do } \\
\text { Governo de suspender o uso de madeiras tropicais. }\end{array}$ \\
\hline 1989 & Alemanha & $\begin{array}{l}\text { A Federação dos Importadores de Madeiras } \\
\text { Tropicais introduz um código de conduta para os } \\
\text { importadores desta commodity. }\end{array}$ \\
\hline 1989 & $\begin{array}{l}\text { European Federation of } \\
\text { Tropical Timber Trade } \\
\text { Association }\end{array}$ & $\begin{array}{l}\text { Impõe uma taxa sobre as importações de madeiras } \\
\text { tropicais pela Comunidade Européia. }\end{array}$ \\
\hline 1994 & $\begin{array}{l}\text { Convenção Internacional } \\
\text { sobre Espécies Avançadas } \\
\text { (CITES) }\end{array}$ & $\begin{array}{l}\text { Votada a inclusão do mogno na lista de espécies } \\
\text { ameaçadas e sujeito, portanto, a controle de } \\
\text { exploração a nível mundial }\end{array}$ \\
\hline
\end{tabular}

Fonte: Angelo (1998); BNDES (1995)

${ }^{\mathrm{A}}$ Essa medida foi, posteriormente, rejeitada pela Comissão Européia.

${ }^{\mathrm{B}}$ Tal moção, encaminhada pela Holanda, não foi aprovada por não ter alcançado a maioria necessária de dois terços, já que houve 33 votos contrários à inclusão e 50 votos de países a favor.

O Brasil também estabelece restrições ao comércio de madeiras nativas. As exportações brasileiras de madeiras da Amazônia e de outras regiões obedecem a cotas estipuladas pelo Instituto Brasileiro do Meio Ambiente e dos Recursos Naturais Renováveis (IBAMA). Por exemplo, as exportações de madeira serrada das espécies mogno, virola, imbuía e araucária são sujeitas ao Sistema de Contingenciamento de Madeira (SCM).

Além dessas questões, conforme observa Hilgemberg (2000, p.3), 
"As exigências ambientais acabaram por evoluir para o estabelecimento de certos padrões de performance ou para a adoção de determinadas práticas que conferissem ao produtor um selo ou certificado capaz de informar ao consumidor que o produto fora produzido por intermédio de processos ambientalmente sustentáveis".

Sobre esse aspecto, programas de qualidade segundo as normas da Internacional Standard Organization (série ISO 14000) e a certificação dos produtos florestais, como o QUALIFOR e o selo verde ${ }^{16}$, tornaram-se instrumentos que permitem às empresas demonstrarem a qualidade ambiental dos produtos e diferenciá-los no mercado, representando, portanto, conforme observam Silva \& Bravo (1994), uma vantagem competitiva. Segundo esses autores, as políticas ambientais dos países desenvolvidos têm enfatizado o papel da informação, visando influenciar as decisões de compra dos consumidores para estimular as empresas a atuarem de forma ambientalmente segura.

Cabe ainda observar, de acordo com Hilgemberg (2000), que em vários países, principalmente os europeus, onde a legislação do meio ambiente é mais rigorosa, a certificação é condição sine qua non para a entrada de certos produtos no mercado.

Não obstante, o custo financeiro envolvido no processo de adequação aos padrões ambientais mundiais é considerável. A título de ilustração, cabe mencionar

\footnotetext{
${ }^{16}$ De acordo com o artigo ISO 14000: a excelência total em meio ambiente (1996), a ISO 14000 fornece um conjunto de normas que possibilita à empresa obter certificado de que os produtos que fabrica ou comercializa não são perigosos ao meio ambiente. Entre as áreas contidas na série ISO 14000 estão: sistemas de gestão ambiental, avaliação do desempenho ambiental, avaliação do ciclo de vida dos produtos, aspectos ambientais nas normas de produtos, rotulagem ambiental e auditoria ambiental.

Ainda segundo o mesmo artigo, o Programa QUALIFOR, desenvolvido pela empresa britânica SGS Forestry, foi estruturado para atender os princípios e critérios do FSC (Forest Stewardship Council), um conselho mundial de manejo florestal o qual permite a certificação com reconhecimento internacional de empresas com atividades ligadas ao manejo florestal. As organizações que recebem a certificação pelo Programa QUALIFOR demonstram seu comprometimento com as questões sociais, ambientais e da viabilidade econômica do manejo de suas florestas através de um sistema de manejo documentado, atendendo requisitos, normas e protocolos internacionalmente reconhecidos.

Com relação ao selo verde, é um programa de rotulagem ambiental que atesta que o produto e seu processo de produção não impactam (ou o fazem minimamente) o meio ambiente em relação a outros produtos similares disponíveis no mercado (Nahuz, 1995).
} 
o processo de obtenção do certificado ISO 14001 no caso da Bahia Sul, empresa do setor de papel e celulose. Segundo Silva ${ }^{17}$, citado por Hilgemberg (2000, p.119),

"A mobilização para obter a certificação envolveu todos os níveis da empresa, clientes e fornecedores, num trabalho que durou 20 meses e consumiu US\$1 milhão. A empresa promoveu treinamentos que somaram $20 \mathrm{mil}$ horas/homem e a normatização de 872 procedimentos internos"

O acréscimo de custos para a incorporação de práticas e técnicas visando o manejo sustentado das florestas, dada a atual estrutura de oferta, também dificulta sobremaneira a participação do Brasil no comércio internacional de madeira serrada e seus produtos, quando há presença de barreiras ambientais.

O reflexo disso nas exportações brasileiras de madeira serrada é a preferência dada para os produtos de reflorestamentos. Ilustra esse fato o aumento das exportações de madeira serrada de coníferas no período de 1995 a 1999, cerca de 21,3\% ao ano. No mesmo período as exportações de madeira serrada das espécies folhosas decresceram, em média, 5,1\% ao ano (ver Gráfico 4).

Outro aspecto observado é o redirecionamento das exportações para espécies desconhecidas do mercado até pouco tempo atrás, como argelim vermelho (Dinizia excelsa), jatobá (Himenaea courbaril), ipê (Tabebuia spp) e louro (Ocotea spp). Já espécies tradicionais, como o mogno e a virola, tiveram uma redução de $10 \%$ e $24 \%$, respectivamente, nas exportações em 1995, de acordo com o artigo Diversificação garante exportação de madeira (1996).

Resta, finalmente, observar que um dos maiores entraves à maior participação do Brasil no mercado internacional de madeira serrada é a própria estrutura de oferta de exportação, realizada basicamente por pequenas e médias empresas. Segundo Macedo et al. (1997), as cinco principais empresas exportadoras de madeira serrada no Brasil, a saber, Nordisk Timber Ltda., Eldorado Exportações e Serviços

\footnotetext{
${ }^{17}$ Silva, M. J. A gestão ambiental no setor de celulose e papel. Celulose \& Papel, n.54, p.11-15,
} 
Ltda., Maginco Madeiras Araguaia S.A., Exportadora Peracchi Ltda. e Serraria Marajoara, concentram menos de $20 \%$ das exportações brasileiras. Esse quadro, de acordo com os mesmos autores, indica a situação de vulnerabilidade das exportações, uma vez que o porte médio das empresas dificulta investimentos em tecnologia, comercialização e marketing internacional, fatores estes, como também observam Mercado e Campagnani (1988) e Ladeira (1988), absolutamente necessários para aumentar a competitividade das vendas externas desse segmento.

\subsection{O segmento produtor de painéis à base de madeira}

O compensado foi o primeiro painel à base de madeira de importância no mercado e sua produção em escala industrial, segundo Zugman (1994), teve início em meados do século XIX ${ }^{18}$. Com o desenvolvimento das resinas sintéticas, na década de 50, a produção do compensado prosperou, alavancando, também, a produção de outros painéis como a chapa dura de fibras e o aglomerado. $\mathrm{O}$ desenvolvimento desses produtos tornou possível a obtenção de painéis de madeira de grandes dimensões a partir de matéria-prima de pequenas dimensões, até mesmo de resíduos, e menos seletivas em relação as espécies empregadas.

Segundo Brito (1996), a indústria de chapas de aglomerado se desenvolveu em função de que, com o crescente aumento da produção de serrados e compensados, a quantidade de resíduos de madeira cresceu proporcionalmente. Além disso, as madeiras mais apropriadas para a industrialização foram escasseando na medida em que o consumo aumentava, restando um grande volume de madeiras menos nobres, até então carecendo de um mercado consumidor.

O desenvolvimento tecnológico na produção das chapas reconstituídas, aliado às dificuldades de acessibilidade à matéria-prima florestal (devido as

\footnotetext{
mar./abr.1997.

${ }^{18}$ Cumpre observar que, de acordo com Tomaselli (1998), o desenvolvimento industrial do compensado ocorreu no início do século XX. Segundo Zaniolo (1988), a indústria moderna de lâminas e compensados nasceu na Europa no final do século XIX.
} 
controvérsias ambientais e exaustão das fontes tradicionais de suprimento), tem levado, em anos recentes, a oferta crescente de produtos reconstituídos no mercado, a exemplo das chapas de MDF (Medium density fiberboard), OSB (oriented strand board), LVL (laminated veneer lumber), PSL (parallel strand lumber), entre outras.

Em 1999, a produção mundial de painéis à base de madeira chegou a cerca de 160 milhões de $\mathrm{m}^{3}$, contra apenas 26,3 milhões de $\mathrm{m}^{3}$ em 1961, o que corresponde a um crescimento médio de 3,9\% ao ano. Contudo, no mesmo período, o comportamento dos três grandes grupos de painéis é bastante diverso (Gráfico 7), com destaque para o crescimento na produção das chapas de aglomerado, em média, 6,4\% ao ano, contra 3,3\% ao ano de crescimento na produção das chapas de fibras e, apenas $2,5 \%$ ao ano de crescimento na produção de compensado.

Gráfico 7 Evolução da produção mundial de painéis à base de madeira no período de 1961 a 1999

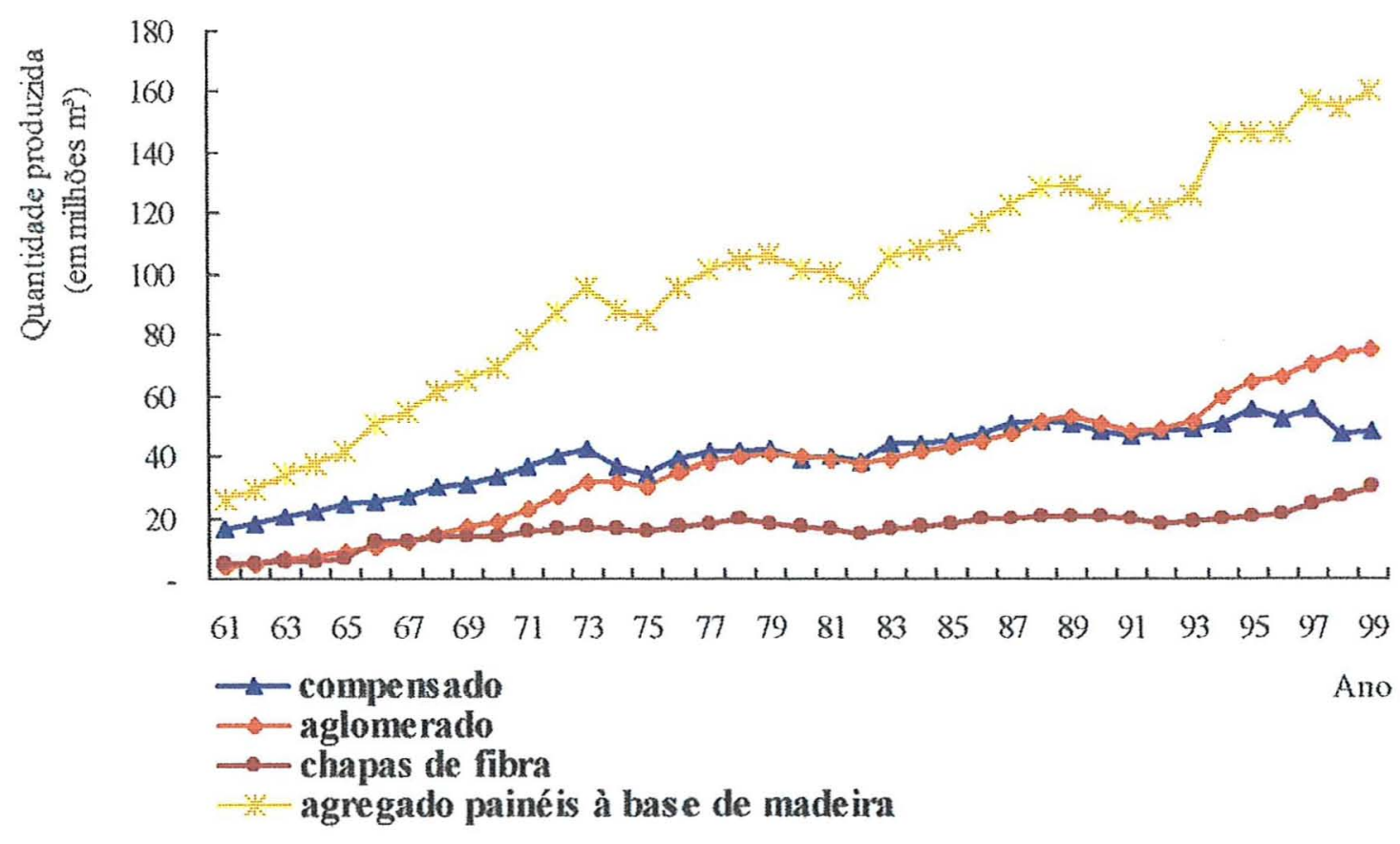

Fonte: home page da FAO (www.fao.org) 
Merece menção a queda na produção mundial de compensado observada na segunda metade da década de 90 , perdendo espaço para as chapas de aglomerado que, em 1999, responderam por cerca de $47 \%$ do total dos painéis produzidos em nível mundial, contra cerca de $30 \%$ do compensado. Conforme mostra o Gráfico 8, no começo dos anos 60 essa proporção era de $15 \%$ contra 63\%, respectivamente.

Grófico 8 Evolução da participação da produção dos principais grupos de painéis sobre a produção mundial do agregado painéis à base de madeira no período de 1961 a 1999

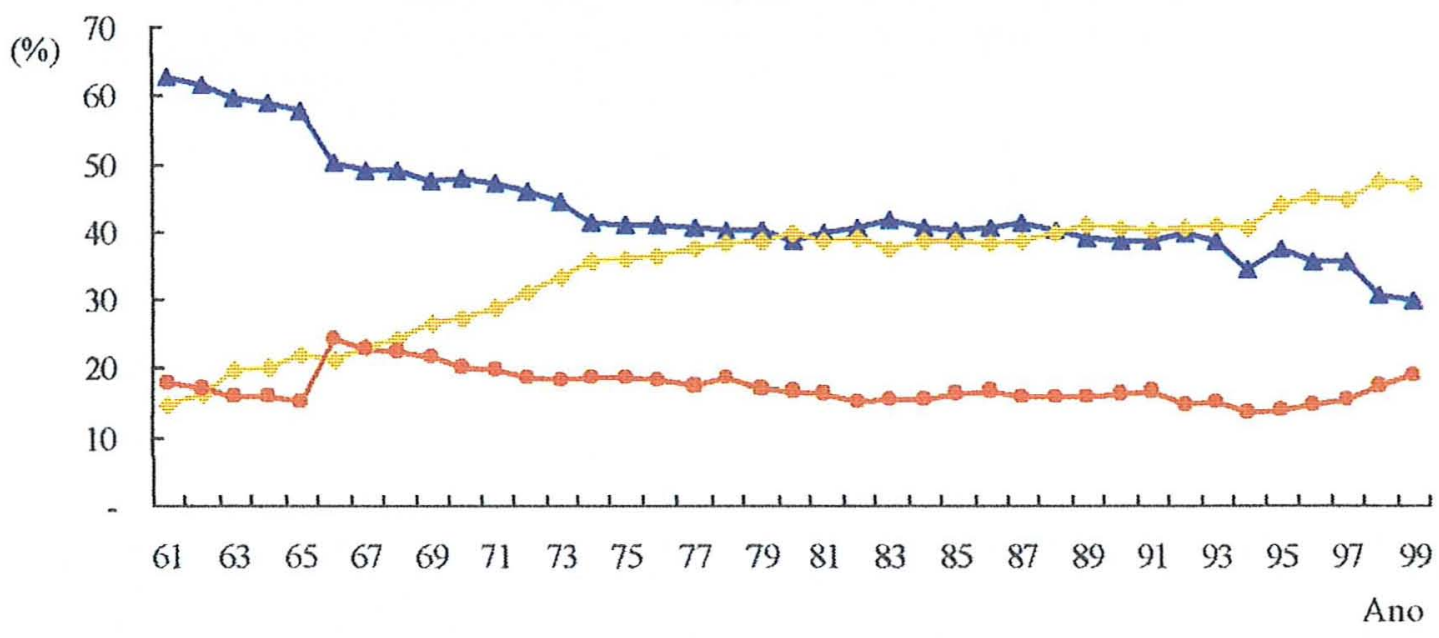

- compensado - aglomerado - - chapas de fibra

Fonte: home page da FAO (www.fao.org)

Cabe observar, de acordo com Macedo \& Roque (1997), que o compensado é um produto com tecnologia de produção consolidada, o qual vem sofrendo restrições de natureza ambiental em seu consumo e escassez de matéria-prima para sua produção. A baixa disponibilidade de toras adequadas para laminação e seus elevados custos tendem a reduzir a oferta de compensado em todo o mundo.

Em função disso, a madeira serrada e o compensado vêm perdendo mercado para os produtos reconstituídos de madeira em alguns nichos de mercado 
específicos, como móveis seriados. Nesse ramo de produção, o compensado vem sendo substituído pelos painéis de aglomerado e MDF.

Segundo dados da FAO e da STCP, a produção mundial de MDF no período de 1995 a 1999 cresceu, em média, 19,2\% ao ano. Ao longo do período de 1980 a 1995, os painéis de OSB cresceram a uma taxa média anual de 19\%. Este quadro mostra claramente uma mudança na composição da produção de modo a aumentar a importância dos painéis de madeira com elevado grau de elaboração, o que também vem sendo observado no segmento de serrados.

O Gráfico 9 mostra os maiores produtores mundiais de painéis à base de madeira. Como se observa, os Estados Unidos, a China, o Canadá e a Alemanha concentraram cerca de $60 \%$ da produção em 1999. Os Estados Unidos, maior produtor para todos os produtos, foi responsável por $25,8 \%$ da produção mundial de painéis à base de madeira em 1999.

Gráfico 9 Principais países produtores de painéis à base de madeira em 1999

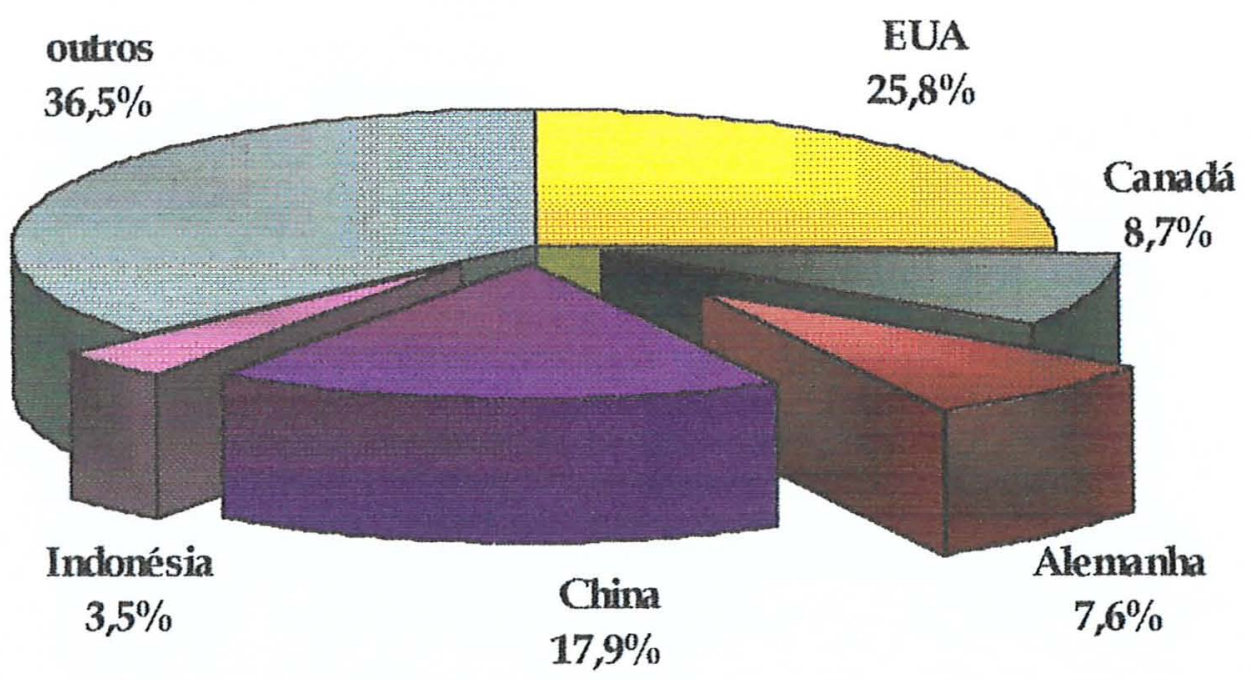

Fonte: home page da FAO (www.fao.org) 
Cumpre observar que no mercado de certos produtos, como o compensado e o OSB, a concentração é ainda maior. Segundo Tomaselli (1998), no caso específico do OSB, a produção é basicamente concentrada nos Estados Unidos e Canadá, os quais são responsáveis por cerca de $95 \%$ da produção mundial.

Em termos regionais, a América do Norte, a Ásia e a Europa concentravam, em 1999, cerca de $93 \%$ da produção mundial de painéis de madeira. Sob esse aspecto, observa-se, também, uma tendência à especialização. As chapas de aglomerado têm sua fabricação concentrada na Europa, cerca de $48 \%$ da produção mundial; no caso do compensado, a Ásia é responsável por $44,6 \%$ da produção e a América do Norte por cerca de $37 \%{ }^{19}$.

A evolução da produção brasileira de painéis à base de madeira, bem como a sua participação na produção mundial são apresentadas no Gráfico 10. Cabe observar que, embora pequena a participação brasileira na produção mundial $(1,9 \%$ em 1999), no periodo analisado o crescimento médio da produção brasileira de painéis foi de $6,8 \%$ ao ano, quase o dobro da média mundial.

\footnotetext{
${ }^{19}$ Informações válidas para 1999.
} 


\section{Gráfico 10 Evolução da produção brasileira de painéis à base de madeira e sua proporção em relação à produção mundial no período de 1961 a 1999}

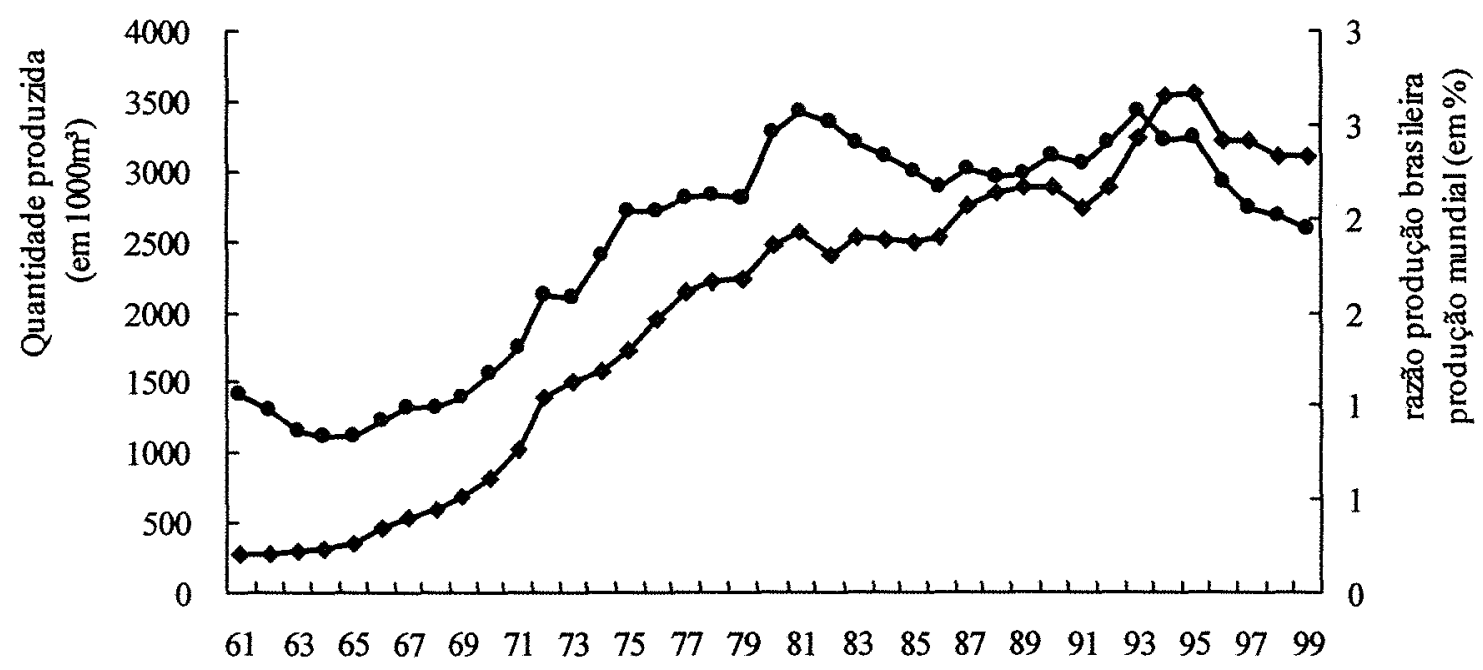

Ano

\section{$\rightarrow$ produção}

$\rightarrow$ proporção da produção brasileira em relação à produção mundial

Fonte: home page da FAO (www.fao.org)

O comércio internacional de painéis à base de madeira cresceu de forma consistente ao longo de todo o período de 1961 a 1999, apresentando uma taxa média de crescimento de cerca de 6,8\% ao ano, alcançando, em 1999, 56,2 milhões de $\mathrm{m}^{3}$, cerca de $35 \%$ da produção mundial, contra menos de $12 \%$ na década de 60 .

Os principais mercados para os painéis de madeira são os Estados Unidos, a China e o Japão. Novamente, os Estados Unidos se destacam como o principal mercado consumidor para todos os tipos de painéis e concentram cerca de $33,6 \%$ do consumo mundial ${ }^{20}$. No caso específico de alguns painéis à base de madeira, como o OSB, a concentração é ainda maior. Nesse caso, o mercado americano consome mais de $80 \%$ do volume atualmente produzido.

\footnotetext{
${ }^{20} \mathrm{O}$ consumo aparente (= produção + importação - exportação) é usado como proxy para o consumo.
} 
O Gráfico 11 traz os principais exportadores mundiais de painéis à base de madeira em 1999. Como pode ser observado, os três maiores exportadores detêm 43,7\% do total exportado. O Canadá lidera o mercado com 18,9\% das exportações mundiais de painéis, seguido da Indonésia com 15\% e da Malásia com $9,8 \%$.

\section{Gráfico 11 Principais países exportadores de painéis à base de madeira em 1999}

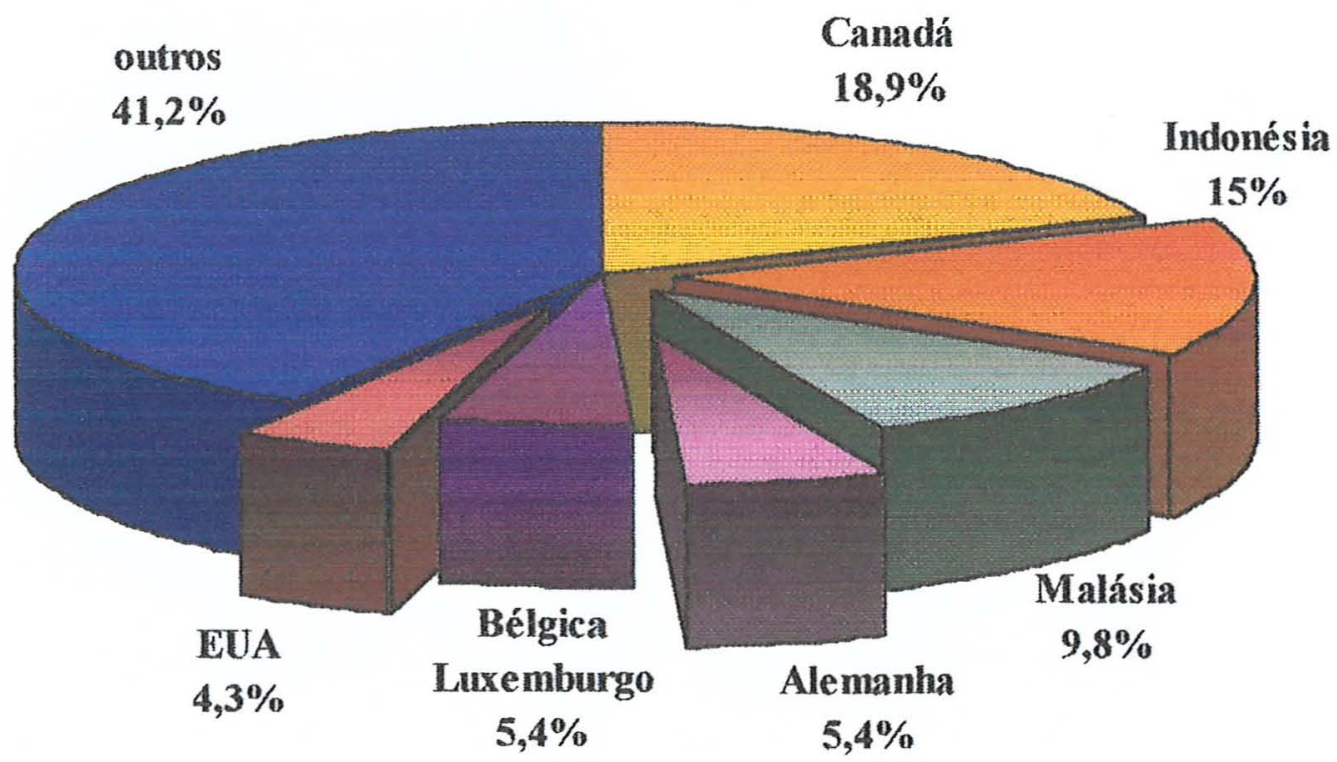

Fonte: home page da FAO (www.fao.org)

Cabe observar, a exemplo do que ocorre na produção, que a concentração é ainda maior no mercado de certos produtos, como no caso do compensado, onde Indonésia e Malásia detêm 55,2\% das exportações mundiais. Merece menção, conforme estudo do BNDES (1995), o fato de que, no ano de 1992, aqueles países apresentaram produção de compensados 6,9 e 4,8 vezes maior que o volume consumidos nos seus respectivos mercados nacionais. Em outras palavras, Indonésia e Malásia possuem grandes excedentes de produção de compensado para atender ao mercado externo. 
Em termos regionais, a Europa concentrava em 1999 cerca de $40 \%$ das exportações mundiais de painéis à base de madeira, contra $29,7 \%$ da Ásia e $23,4 \%$ da América do Norte.

O Brasil, sozinho, é responsável por, aproximadamente, $60 \%$ das exportações de painéis de madeira da América Latina. Contudo, o País nunca teve uma participação muito expressiva nas exportações mundiais. Em 1999, o Brasil contribuiu com apenas $2,5 \%$ do volume total de painéis de madeira comercializados no mercado internacional.

Não obstante, no período de 1961 a 1999 as exportações brasileiras de painéis à base de madeira cresceram, em média, $11,9 \%$ ao ano, atingindo 1,4 milhão de $\mathrm{m}^{3}$ naquele último ano. Isso correspondeu a $45 \%$ da produção nacional de painéis, contra apenas $5 \%$ no início da década de 60 .

\subsubsection{A indústria e as exportações brasileiras de compensado}

Segundo Zugman (1998), a estrutura de produção de compensado contava, em 1998, com cerca de 300 unidades industriais, com capacidade instalada de 2,2 milhões de $\mathrm{m}^{3}$, onde as 40 maiores empresas eram responsáveis por cerca de $60 \%$ dessa capacidade.

As empresas de pequeno porte apresentam estrutura de produção tipicamente familiar. Isso é conseqüência do seu próprio processo de desenvolvimento, bastante diverso do observado em outros países. Sobre esse aspecto, como também ocorre no caso da indústria de madeira serrada, a implantação da indústria de lâminas e compensado, bem como a disponibilização de meios de produção para o seu desenvolvimento, foram determinados pelo esforço dos imigrantes europeus. Conforme Zugman (1998, p.50),

"Nisto o Brasil diferencia-se de outros países em desenvolvimento, particularmente dos países do sudeste asiático, onde tecnologia e capital foram trazidos, em sua grande parte, por investidores 
estrangeiros muitas vezes representando grandes corporações com interesse a atender o mercado de sua origem".

Estudo da ABIMCI e da Organização Internacional de Madeiras Tropicais (OIMT), citado por Zugman (1998), compara o tamanho médio da empresa brasileira de compensado com a instalada em outros paises e constata que, em alguns casos, como o da Indonésia, as unidades industriais são em média dez vezes maiores que as encontradas no Brasil. Conforme mostra o Quadro 3, mesmo em países da América Latina, como o Equador, a capacidade média de produção de uma fábrica de compensado é quase o dobro da instalada no Brasil.

\section{Quadro 3}

Capacidade instalada da indústria de compensado em países selecionados em 1998

\begin{tabular}{|l|c|c|c|}
\hline Países & Número de fábricas & $\begin{array}{c}\text { Capacidade instalada } \\
\left(\mathbf{1 0 0 0} \mathbf{~ m}^{\mathbf{3}} \mathbf{a 0} \mathbf{a n o}\right)\end{array}$ & $\begin{array}{c}\text { Capacidade média } \\
\left(\mathbf{m}^{\mathbf{3}} \mathbf{a 0} \mathbf{a n o}\right)\end{array}$ \\
\hline Brasil & 300 & 2.200 & 7.330 \\
\hline Equador & 8 & 100 & 12.500 \\
\hline Indonésia & 117 & 8.200 & 70.080 \\
\hline Malásia & 79 & 2.900 & 36.700 \\
\hline
\end{tabular}

Fonte: ITTO e ABIMCI, citados por Zugman (1998)

O pequeno porte das unidades industriais produtoras de compensado no Brasil faz com que grande parte delas seja dependente de produtores de lâminas. Cabe observar que, em outros países onde a indústria de compensado está presente, as unidades são predominantemente integradas, havendo produção conjunta de lâminas e compensados.

Macedo \& Roque (1997) apontam também como uma das principais caracteristicas da indústria produtora de painel de compensado no Brasil a inexistência de expressivas barreiras à entrada, no que tange ao volume de investimento requerido. Como resultado disso, a estrutura produtiva é bastante heterogênea, coexistindo unidades com diferentes níveis tecnológicos. 
A indústria de compensados no Brasil pode ser dividida em dois grandes grupos segundo o tipo de madeira utilizada e o nível tecnológico das empresas. O primeiro é constituído por empresas com origem ou instalações no norte do País, especializadas na produção do compensado de madeira tropical, baseado em espécies nativas da Amazônia. Em geral, essas empresas alcançam baixo nível de produtividade e se encontram desatualizadas tecnologicamente. No entanto, elas são responsáveis por $60 \%$ da produção nacional de compensados. O segundo grupo, localizado principalmente na Região Sul, é voltado para o processamento de madeiras moles, proveniente de florestas plantadas, com destaque para o pinus elliotti. Essas empresas apresentam bom nível de produtividade, certo grau de modernização industrial e de automação. Elas respondem pelos $40 \%$ restantes da produção nacional.

Mesmo contando com estrutura de produção parcialmente desatualizada (fruto dos inexpressivos investimentos tecnológicos realizados em anos recentes), principalmente quando comparado aos painéis de aglomerado e MDF, a produção brasileira de compensado cresceu, em média, 6,3\% ao ano ao longo de todo o período de 1961 a 1999 , contra apenas $2,5 \%$ da média mundial.

O compensado é, atualmente, o painel disponibilizado em maiores volumes no mercado nacional, quase $50 \%$ dos cerca de 3,1 milhões de $\mathrm{m}^{3}$ de painéis à base de madeira produzidos em 1999.

Cabe observar que, naquele mesmo ano, cerca de $67,7 \%$ da produção nacional de compensado teve como destino o mercado externo, um montante surpreendente quando comparado aos menos de $2 \%$ exportados em meados dos anos 60 . O compensado é o segundo produto da pauta de exportação de madeira (a madeira serrada é o principal produto comercializado externamente).

Ao longo de todo o período analisado, as exportações brasileiras de compensado cresceram, em média, $16 \%$ ao ano, ante a $6,6 \%$ ao ano de crescimento nas exportações mundiais. Não obstante, o crescimento das exportações brasileiras de compensado não foi homogêneo. Como mostra o Gráfico 12, no período de 1994 a 1998 
o volume exportado caiu sensivelmente, o que se deveu à queda nos preços internacionais do compensado e a valorização cambial que ocorreu no Brasil a partir de 1994 (e foi mantida até 1998).

Gráfico 12 Evolução das exportações brasileiras de compensado no período de 1961 a 1999

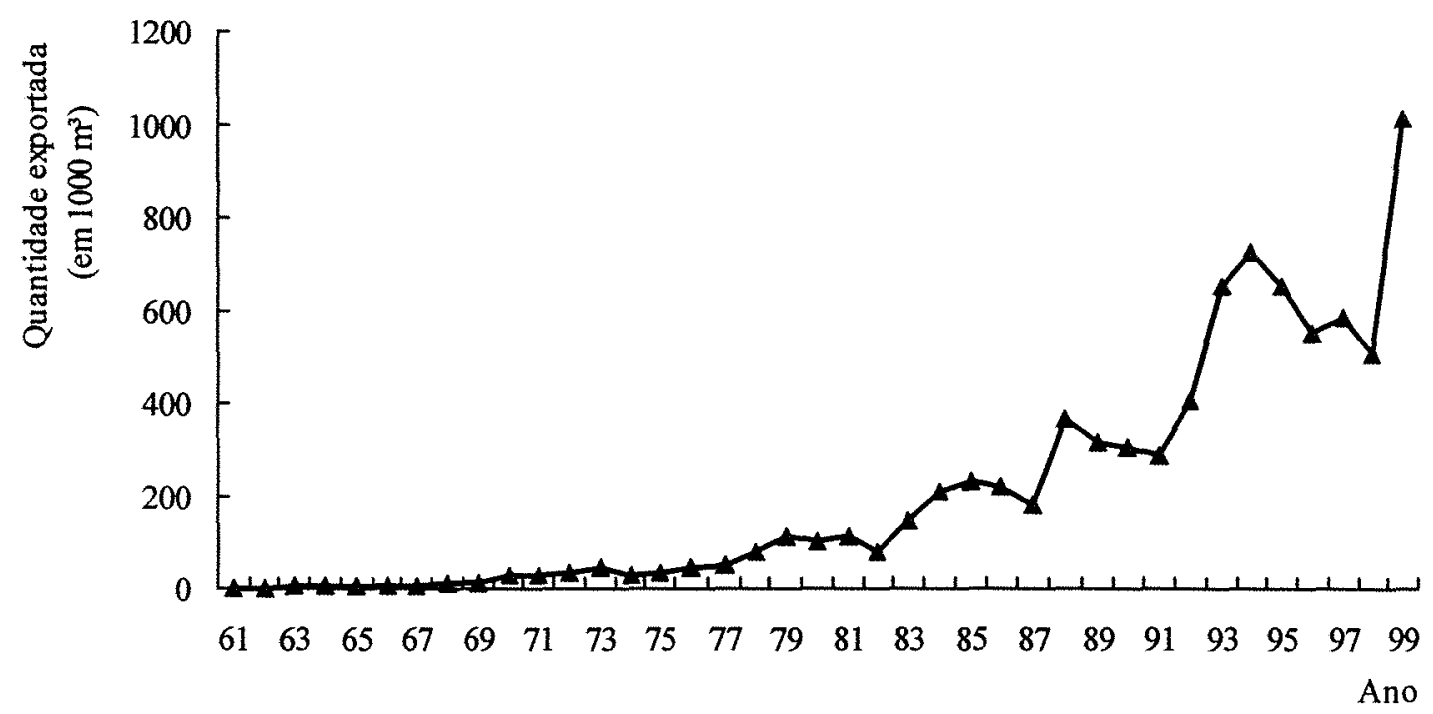

Fonte: home page da FAO (www.fao.org)

Convém observar que a crise asiática no começo de 1997 intensificou, ainda mais, a redução das exportações brasileiras de compensados. A combinação de queda na demanda no mercado de madeiras tropicais, alavancada pela grande redução nas importações da Tailândia e Filipinas (até aquele momento, respectivamente, o primeiro e o terceiro importadores de madeira tropical do mundo), e a desvalorização das taxas de câmbio de importantes países produtores, como Indonésia e Malásia, fizeram com que o preço do compensado tropical no mercado externo despencasse.

A esse respeito, Adams \& Johnson (1998, p.27) afirmam:

"Em março de 1997, os preços dos compensados de lâminas finas da Indonésia e da Malásia oscilaram entre US\$445 e US\$455 o metro cúbico. Em agosto daquele mesmo ano, estes preços haviam diminuído entre quatro e oito por cento, enquanto que em fevereiro de 1998 
haviam sofrido uma brusca queda de 30 por cento em relação ao mês anterior.(...) Os preços de fevereiro de 1998 para os painéis/tábuas de madeira da Malásia e da Indonésia foram de US\$280 a US\$295 por metro cúbico, enquanto que os produtores brasileiros seguem mantendo seus preços de US $\$ 340$ a US $\$ 360$ por metro cúbico, ainda que a este nível estejam exportando muito pouco".

É importante dimensionar a sensível redução do "tamanho do mercado" do compensado em todo o mundo na segunda metade da década de 90 . Ao longo do período de 1996 a 1999, o volume de comércio no mundo decresceu, em média, 1,4\% ao ano. Em alguns mercados específicos, como os Estados Unidos e a Indonésia, essa redução chegou, em média, a $24,2 \%$ e $16 \%$ ao ano, respectivamente.

Como se pode observar, a escassez de demanda, a redução nos preços do compensado no mercado internacional e a precária estrutura de produção da indústria doméstica comprometeram o desempenho recente das exportações brasileiras de compensado. Além, é claro, das fortes restrições ambientais que o produto vem sofrendo em todo o mundo, em função, sobretudo, das perdas envolvidas no seu processo de produção e do uso de madeira de florestas nativas.

Vale destacar que o compensado baseado no pinus, produto em franca ascensão da produção, reúne características que podem torná-lo altamente competitivo tanto no mercado externo quanto no mercado doméstico. Além dos menores custos de produção, o que se reflete em um produto final com preços até $40 \%$ menores que os do compensado de madeira tropical, o apelo ecológico de produtos baseados em espécies oriundas de reflorestamentos é um forte elemento de marketing. Aliás, a recuperação das exportações brasileiras de compensado em 1999 é resultado do aumento das exportações de compensado de pinus ${ }^{21}$.

\footnotetext{
${ }^{21} \dot{E}$ importante frisar que, afora a questão ambiental, a redução nos preços do compensado tropical no mercado internacional incitou as exportações do compensado de pinus. Segundo Tomaselli (1998), em 1998 os preços do compensado de madeira tropical estavam tão baixos, a ponto de serem comparáveis aos preços de compensado de pinus. Como já observado, este último tem preço até $40 \%$ menor que o compensado de madeira tropical.
} 
Macedo et al. (1997), com base na análise do market share, observam que as exportações brasileiras de compensado, em grande parte destinadas aos Estados Unidos e Reino Unido, e que até os anos 80 ocupavam posições marginais nesses mercados, aumentaram sua participação a partir da primeira metade da década de 90 . Não obstante, como mostra a Tabela 4, na segunda metade da referida década ocorreu uma sensível redução do market share. Isto se deveu aos fatores já citados.

Tabela 4

Market Share nos principais países importadores de painel de compensado brasileiro

$(\mathrm{em} \%)$

\begin{tabular}{lllll}
\hline Países & 1985 & 1990 & 1994 & 1998 \\
\hline Estados Unidos & $1^{(4)}$ & $4^{(3)}$ & $17^{(2)}$ & $3^{(2)}$ \\
Reino Unido & $6^{(6)}$ & $5^{(6)}$ & $18^{(2)}$ & $11^{(3)}$ \\
\hline
\end{tabular}

Fonte: Macedo et al. (1997); home page $\mathrm{FAO}$ ( $w w w$. fao.org)

OBS. Os números entre parênteses se referem a colocação do Brasil entre os principais fornecedores do mercado importador.

Segundo os mesmos autores, de forma semelhante ao que ocorre no mercado de serrados de não coníferas, o principal fornecedor mundial (Indonésia) domina amplamente os mercados com maiores taxas de crescimento da demanda (Japão, China, Coréia e Hong Kong), enquanto grande parte das exportações brasileiras é destinada a países em cujos mercados as importações de compensados estão quase estagnadas.

O Gráfico 13 mostra as maiores empresas exportadoras de painéis de compensado, as quais detêm apenas $23 \%$ das vendas externas. Cabe observar que, a exceção da Eidai do Brasil, a qual pertence ao grupo Mitsubishi, a indústria de compensados no Brasil é dominada por empresas de pequeno e médio porte. 


\section{Gráfico 13 Principais empresas exportadoras de painel de} compensado no Brasil em 1996

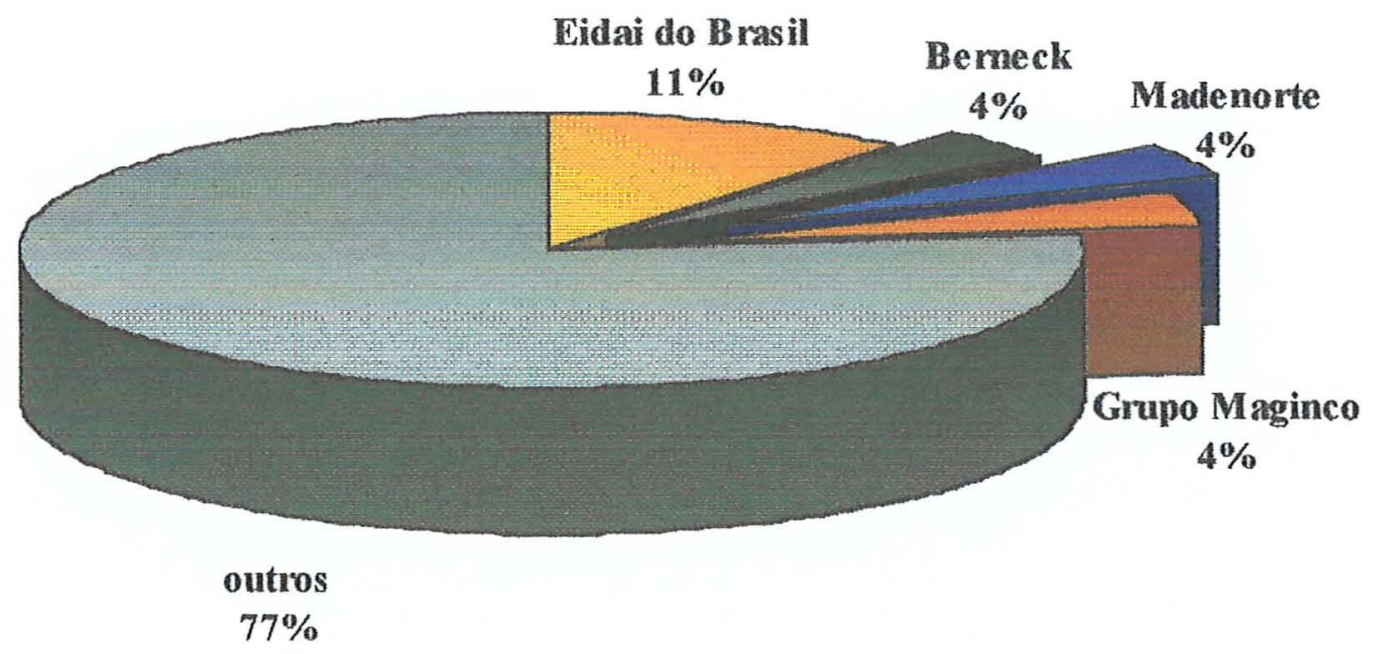

Fonte: home page da FAO (www.fao.org)

Sobre esse aspecto, Zugman (1998) aponta algumas desvantagens acerca do tamanho das empresas produtoras do compensado no Brasil, conforme seguem:

a) a pequena capacidade de investimento reduz a competitividade em toda a cadeia de produção;

b) determinados mercados não podem ser atingidos por limitações de volumes na produção;

c) a sustentabilidade da base florestal nem sempre é possível, pela própria falta de capacidade de investimento da empresa. 


\subsubsection{A indústria e as exportações brasileiras de aglomerado}

As primeiras empresas produtoras de painéis de aglomerado, a Solidor e a Neoplam, iniciaram suas atividades no Brasil em 1953 e 1954, respectivamente. Contudo, é com a instalação maciça de novas plantas industriais, entre elas a Madequímica, Placas do Paraná, Alplan, Freudenberg e Satipel, em meados dos anos 60, que a indústria de madeira aglomerada passou a ter expressão econômica no Brasil.

Conforme Roque \& Valença (1998), a capacidade instalada da indústria nacional de aglomerado passou de $40 \mathrm{mil} \mathrm{m} 3 /$ ano em 1967 para cerca de 630 mil mªno em 1975 , valor bastante superior à demanda de painéis de aglomerado naquele ano, que foi de $370 \mathrm{mil} \mathrm{\textrm {m } ^ { 3 }}$.

Segundo os mesmos autores, nos anos 80 , a capacidade instalada manteve-se praticamente inalterada e a produção estagnada. Esses fatos decorreram da relativa abundância de madeiras nobres e ausência de qualquer política ambiental que restringisse efetivamente a exploração das florestas nativas, direcionando a produção de madeira para outras atividades, sobretudo os serrados e compensados.

Os equipamentos empregados por grande parte dos fabricantes brasileiros de aglomerado foram instalados nas décadas de 60 e 70 . As prensas mais antigas, monovão e multivão, representam quase $80 \%$ da capacidade instalada. Apenas duas empresas operam com prensas contínuas, tecnologia amplamente utilizada na Europa e Estados Unidos.

Roque \& Valença (1998) destacam o baixo nível de investimento em modernização das plantas industriais de aglomerado, o que reduz substancialmente a capacidade efetiva de produção, face à obsolescência de boa parte dos equipamentos produtivos. Esse fato, segundo os autores, ficou patente nos anos de 1996 e 1997, quando a produção nacional atingiu um volume da ordem de 1,2 milhão de $\mathrm{m}^{3}$, obrigando a indústria moveleira a recorrer a importações de aglomerados, principalmente da Argentina e do Chile. 
Em 1998, a capacidade nominal de produção da indústria de chapas de aglomerado era de cerca de 1,8 milhões de $\mathrm{m}^{3}$ ao ano, sendo realizada por apenas sete empresas, caracterizando uma oferta bastante concentrada, conforme se observa no Quadro 4.

\section{Quadro 4}

Capacidade instalada da indústria brasileira de painéis de aglomerado em 1998

\begin{tabular}{|l|c|c|c|c|}
\hline Empresa & $\begin{array}{l}\text { Capacidade } \\
\text { Instalada } \\
\left(\mathbf{m i l ~ m}^{\mathbf{3}}\right)\end{array}$ & $\mathbf{( \% )}$ & $\begin{array}{l}\text { Número de } \\
\text { unidades } \\
\text { industrias }\end{array}$ & $\begin{array}{l}\text { Localização } \\
\text { Geográfica }\end{array}$ \\
\hline Berneck Aglomerados S.A. & 360 & 20 & 1 & $(\mathrm{PR})$ \\
\hline Duratex S.A. & 336 & 19 & 2 & $(\mathrm{RS}, \mathrm{SP})$ \\
\hline Satipel Industrial S.A. & 334 & 19 & 2 & $(\mathrm{RS}, \mathrm{MG})$ \\
\hline Placas do Paraná S.A. & 300 & 17 & 1 & $(\mathrm{PR})$ \\
\hline Eucatex S.A. & 240 & 13 & 1 & $(\mathrm{SP})$ \\
\hline Tafisa Brasil S.A. & 168 & 9 & 1 & $(\mathrm{PR})$ \\
\hline Bonel & 60 & 3 & 1 & $(\mathrm{SC})$ \\
\hline Total & 1.798 & 100 & 9 & \\
\hline
\end{tabular}

Fonte: Associação Brasileira da Indústria de Painéis de Madeira (ABIPA), citado por Valença et al. (1999)

Com relação à distribuição geográfica da produção, as regiões Sul e Sudeste concentravam, em 1998, 93\% da produção de painéis de aglomerado, sendo o Estado do Paraná responsável por $46 \%$ desse total (Valença et al., 1999).

Cabe observar, conforme Valença et al. (1999), que a localização das empresas produtoras de aglomerado nessas regiões deve ser analisada considerando a concentração dos pólos moveleiros, posto que entre $80 \%$ e $90 \%$ da produção desses painéis são absorvidos pela indústria de móveis. A proximidade com esses pólos é estratégia para garantir um mercado às empresas de aglomerado, devido aos menores custos de transporte. 
As exportações brasileiras de chapas de aglomerado são pouco expressivas, correspondentes a $1,7 \%$ do volume de painéis à base de madeira exportados no ano de 1999. Essas exportações destinam-se a países da América do Sul. Essa, aliás, é uma característica do próprio produto que, por apresentar baixo valor específico, leva $o$ comércio se realizar, principalmente, entre países próximos, pertencentes a um mesmo bloco econômico.

O Gráfico 14 mostra a evolução das exportações brasileiras de painéis de aglomerado. Pode-se observar que o "boom" do quantum exportado ocorreu no começo dos anos 90, quando as exportações cresceram, em média, 47,9\% ao ano, passando de 8,2 mil m³ em 1990 para, aproximadamente, $66 \mathrm{mil} \mathrm{m}^{3}$ no ano de 1996. Esse quadro reverte-se nos três últimos anos de análise, quando as exportações decresceram, em média, $23,5 \%$ ao ano.

\section{Gráfico 14 Evolução das exportações brasileiras de aglomerado no período de 1972 a 1999}

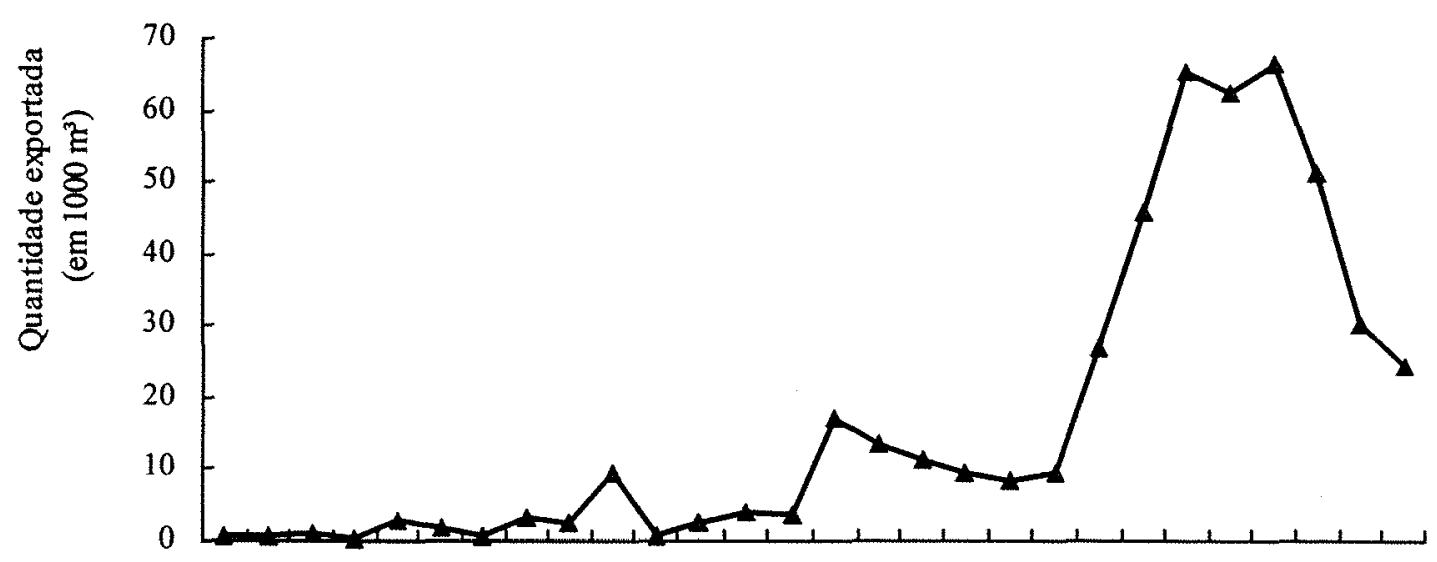

72737475767778798081828384858687888990919293949596979899

Ano

Fonte: home page da FAO (www.fao.org)

O cenário acima descrito merece alguns comentários. Primeiramente, o bom desempenho das exportações brasileiras de aglomerado, na primeira metade da década de 90 esteve, em grande parte, relacionado ao dinamismo do comércio mundial 
que cresceu, em média, $10 \%$ ao ano ao longo de toda a década de 90 . A redução das exportações de aglomerado, na segunda metade da década de 90 , esteve associada à valorização do real e ao crescimento da demanda interna por este produto. $O$ crescimento da demanda interna de aglomerado, nessa época, é explicado pelo crescimento expressivo da indústria moveleira no Brasil, onde o compensado vem sendo gradativamente substituído pelos painéis de aglomerado. $\mathrm{O}$ ritmo de crescimento do consumo nacional de aglomerado, no periodo de 1990 a 1998, foi bastante significativo, cerca de $13 \%$ ao ano.

Cumpre observar que o dinamismo do mercado doméstico alavancou os preços do aglomerado, o que fez com que muitos exportadores direcionassem suas vendas para o mercado interno. A título de exemplo, no ano de 1996, o nível de preços atingido viabilizou importações até mesmo da Europa, o que realmente surpreende, dado que o aglomerado é bastante sensível ao custo de transporte.

A Tabela 5 apresenta os maiores exportadores mundiais de painéis de aglomerado e seu desempenho recente. Como se observa, o Brasil ocupa uma posição marginal neste mercado, visto que participa com apenas $0,1 \%$ das exportações mundiais. Não obstante, obteve uma das mais altas taxas de crescimento quando comparado com os maiores exportadores (se considerado apenas o período de 1990 a 1996 a taxa é mais alta de todas, o dobro do segundo colocado). 
Tabela 5

Maiores exportadores mundiais de painel de aglomerado em anos selecionados $\left(\mathrm{em} \mathrm{mil} \mathrm{m^{3 } )}\right.$

\begin{tabular}{lrrrrr}
\hline Países & $\mathbf{1 9 8 0}$ & $\mathbf{1 9 9 0}$ & $\mathbf{1 9 9 5}$ & $\mathbf{1 9 9 9}$ & $\begin{array}{r}\text { Taxa Anual de } \\
\text { Crescimento } \\
(\mathbf{1 9 9 0} \text { a 1999) }\end{array}$ \\
\hline Canadá $^{(36,2 \%)}$ & 540 & 1.555 & 4.302 & 7.782 & 22,8 \\
\hline Bélgica Luxemburgo $^{(9,8 \%)}$ & 1.164 & 1.839 & 1.942 & 2.111 & 2,0 \\
\hline Alemanha $^{(7,4 \%)}$ & 660 & 1.025 & 1.245 & 1.596 & 6,6 \\
\hline França $^{(6,2 \%)}$ & 372 & 588 & 999 & 1.339 & 10,5 \\
\hline Áustria $^{(5,5 \%)}$ & 675 & 1.022 & 1.025 & 1.184 & 3,6 \\
\hline Estados Unidos $^{(2,8 \%)}$ & 227 & 650 & 496 & 591 & $(3,4)$ \\
\hline Brasil $^{(0,1 \%)}$ & $\mathbf{3}$ & $\mathbf{8}$ & $\mathbf{6 2}$ & $\mathbf{2 4}$ & $\mathbf{1 4 , 4}$ \\
\hline Outros $^{(0.1 \%)}$ & 2.310 & 2.650 & 4.230 & 6850 & \\
\hline Total & 5.951 & 9.337 & 14.301 & 21.477 & 11,1 \\
\hline
\end{tabular}

Fonte: home page $\mathrm{FAO}$ (www: fao.org)

*Calculada pela autora, utilizando o antilogaritmo $(\delta)-1$, onde $\delta$ é o coeficiente da função $\log X=\alpha+\delta Y$ sendo $\mathrm{X}$ é o quantum exportado e $\mathrm{Y}$ a variável tendência, medida na unidade da série, neste caso em anos. Nota: Os números entre parênteses referem-se a participação de cada país no comércio mundial de chapas de fibra comprimida no ano de 1999.

É importante destacar a boa reputação dos painéis brasileiros no mercado externo, o que se deve ao fato de que a madeira, uma das principais matérias-primas utilizadas para a produção de painéis de aglomerado, provém, em sua totalidade, de florestas plantadas, o que representa um forte elemento de marketing do produto. Segundo Valença et al. (1999), as empresas Placas do Paraná, Tafisa e Berneck empregam $100 \%$ de pinus na fabricação desses painéis. A Eucatex emprega $100 \%$ de eucalipto, enquanto Duratex e Satipel combinam pinus e eucalipto em proporções variadas. 
Outro elemento de diferenciação do aglomerado se refere ao emprego de resíduos de madeira no processo produtivo, característica desses painéis. Conforme Brito (1996), nos Estados Unidos, por exemplo, a indústria de madeira aglomerada tem como principal fonte de matéria-prima os resíduos de coníferas, que perfazem $76,7 \%$ do total da madeira empregada nesta indústria. No Brasil, por sua vez, onde são utilizados unicamente como matéria-prima os cavacos de madeira provenientes de florestas plantadas, a qualidade do painel de madeira aglomerada é superior àquela dos países que utilizam maciçamente resíduos como matéria-prima.

As perspectivas são que as exportações de aglomerado não cresçam na primeira metade da atual década. Não é provável haver excesso de oferta em relação à demanda na indústria de aglomerado nos próximos anos. Segundo Valença et al. (1999), a demanda doméstica de painéis de aglomerado deverá crescer, em média, 11\% ao ano até 2004, o que representaria um entrave ao crescimento das exportações.

Esta situação cria oportunidades para novos investimentos na indústria de aglomerados. Roque \& Valença (1998), considerando as principais características da estrutura produtiva dessa indústria, alertam que as diferenças de custos e de produtividade são essenciais na determinação da competitividade nesta indústria. Assim sendo, segundo os mesmos autores, os novos investimentos deverão direcionar-se, sobretudo, para a atualização tecnológica, a exemplo do processo de prensagem contínua.

A esse respeito, Valença et al. (1999) afirma que,

"Os equipamentos de prensa contínua proporcionam vantagens, especialmente no que se refere ao consumo mais baixo de matériasprimas, à necessidade de menor número de funcionários na operação, às menores perdas no processo de lixamento e à maior produtividade. $O$ consumo de energia elétrica também é menor. Assim sendo, o custo específico de matérias-primas e de energia é significativamente diminuído e o custo total de produção reduz-se entre $10 \%$ e $15 \%$ com a utilização de prensas contínuas vis-à-vis a de prensas monovão/multivão". 
Outro aspecto a ser considerado nos novos investimentos é a integração entre linhas de fabricação de serrados, painéis à base de madeira e a indústria moveleira no que se refere ao aproveitamento de resíduos, atualmente sem utilização econômica.

Brito (1996), baseado em dados de 1991, estimou a produção de resíduos na indústria brasileira de serrados e laminados concluindo, entre outras coisas, que os residuos gerados naquelas indústrias seriam suficientes para produzir 6,94 vezes a quantidade de aglomerados produzidos naquele ano ${ }^{22}$. Segundo os mesmos autores, esses resíduos podem atingir valores até três vezes menores que aqueles pagos pela madeira em tora, o que se traduz em uma economia na aquisição de matéria-prima de até $67 \%$.

Finalmente, considerando-se que o aglomerado standard é um produto homogêneo, com custo de transporte que restringe sua área de comercialização, a agregação de valor aos produtos é crucial para a expansão das exportações, uma vez que a diferenciação do produto, além de permitir ampliar o mercado geográfico, possibilita maior influencia na formação de preços. A Tabela 6 mostra os preços médios de painéis de aglomerado praticados no mercado interno. Pode-se observar que os preços das chapas revestidas são, em média, $70 \%$ maiores que os das chapas cruas.

\footnotetext{
${ }^{22}$ Cumpre observar que um dos entraves, segundo o autor, para a utilização desses resíduos é que as serrarias e laminadoras no Brasil são, em geral, de médio e pequeno porte, e encontram-se espalhadas por várias regiões, enquanto as empresas de aglomerado são poucas e concentradas nas regiões Sul e Sudeste. Isto dificulta a coleta e transporte dos resíduos até as empresas de aglomerado.
} 


\section{Tabela 6}

Preços médios de painéis de aglomerado praticados no mercado intemo $\left(\mathbf{e m ~ R S / m ^ { 3 } )}\right.$

\begin{tabular}{lllll}
\hline Especificação & 1996 & 1997 & 1998 & 1999 \\
\hline Chapas cruas & 248 & 256 & 238 & 239 \\
Chapas revestidas & 417 & 438 & 417 & 417 \\
\hline
\end{tabular}

Fonte: BNDES, citado por Valença et al. (1999)

\subsubsection{A indústria e as exportações brasileiras de chapas de fibra}

O presente item analisa apenas as chapas de fibra prensada, uma vez que o produto não prensado, ou chapa mole (softboard), tem uma participação muito reduzida nas exportações brasileiras de chapas de fibra e é, em nivel mundial, conforme observa Oliveira (1988), um produto em fase final do ciclo de vida.

A tecnologia de produção das chapas de fibra foi desenvolvida nos Estados Unidos no início da década de 30, visando obter um substituto ao compensado, e empregando resíduos de serrarias como matéria-prima. Nos anos 40 e 50, essa tecnologia foi aperfeiçoada na Suécia, o que permitiu a esse país, ao lado da Finlândia, dominar o comércio mundial do produto até o início da década de 70 .

No Brasil, a produção comercial das chapas de fibra dura (chamada de hardboard) teve início em 1955, com a instalação da Duratex, em Jundiaí (SP), e representou a oportunidade de utilizar os reflorestamentos de eucalipto existentes na região. A Eucatex, criada em 1951, em Salto (SP), dedicava-se à produção de chapas acústicas. Em meados dos anos 60, a Eucatex entra na fabricação de chapas prensadas e, em 1974, instala uma segunda prensa, a maior do mundo em dimensão e capacidade de produção. 
Contudo, frente às dificuldades de comercialização das chapas de fibra dura no mercado doméstico, pela tradição no uso do compensado, o mercado externo se tornou o mercado natural do produto, bem como o grande responsável pelo desenvolvimento da indústria nacional.

Com a disputa pela liderança no mercado doméstico, bem como o excelente desempenho das exportações brasileiras de hardboard, em 1973, a Duratex instala uma nova fábrica em Botucatu (SP), cuja prensa, a quarta da empresa, era voltada basicamente para a exportação. Em 1978, a Duratex instala uma segunda prensa naquela unidade e, em 1982, uma terceira prensa, então a mais moderna do mundo no processo úmido de produção.

Segundo Oliveira (1988), no período de 1973 a 1977, as exportações de hardboard representaram $38 \%$ da produção daquelas duas empresas, correspondendo ao dobro do volume e ao quádruplo do valor do período de 1967 a 1972. É nesse período, conforme o mesmo autor, que as chapas duras brasileiras disputam mercado com as chapas suecas, obtendo a liderança no mercado americano, o maior país produtor, consumidor e importador desses painéis.

Os fatos acima expostos revelam a boa penetração da chapa de fibra dura brasileira no mercado externo. O hardboard é o painel brasileiro de maior expressividade no comércio internacional, com uma participação, em 1999, de 7,5\%.

Sobre esse aspecto, Oliveira (1988) observa que a qualidade reconhecida da chapa de fibra dura brasileira, devido a sua matéria-prima, ao domínio de tecnologia e a um controle de qualidade estrito, assegurou sua penetração nos usos mais exigentes da chapa dura, como painéis de revestimento e, sobretudo, capas de porta. $\mathrm{Na}$ produção deste último produto, segundo o mesmo autor, as duas empresas brasileiras chegaram a deter cerca de $70 \%$ do consumo americano de hardboard.

Contudo, cabe observar que se a competitividade e a qualidade desses painéis de fibras duras garantiu, por um lado, novos mercados para as chapas brasileiras, 
por outro, gerou forte protecionismo em alguns mercados consumidores. Conforme expõe Oliveira (1988, p.227)

“(...) depois de dois processos anti-dumping, dos EUA em 1959/61, e do Mercado Comum Europeu (MCE), em 1976, ambos encerrados sem maiores danos para o Brasil, vieram sucessivamente a exclusão do Brasil do SGP $^{23}$ nos EUA, em 1978/79 (chapas não-acabadas), e 1982/83 (chapas acabadas), a diminuição da cota "duty-free" no MCE, em 1982, encerrado em 1983 com o compromisso de respeitar preços mínimos ("undertaking") fixados pelo MCE, bem acima do aceitável pelo mercado".

$\mathrm{O}$ relato acima ilustra algumas das inúmeras barreiras encontradas pelas chapas brasileiras no mercado externo, sobretudo na Comunidade Européia, um mercado altamente protecionista e que, recentemente, como forma de proteção aos produtores locais, introduziu novas barreiras tarifárias, taxando em cerca de $30 \%$ a chapa dura brasileira.

As barreiras ao livre comércio impostas pelo mercado europeu, bem como a proximidade geográfica dos demais concorrentes, entre eles, Suécia e Finlândia, limitaram o acesso do hardboard brasileiro àquele mercado e tornaram as exportações brasileiras altamente concentradas. Cabe observar que essa concentração ainda permanece, como mostra o Gráfico 15. Em 1998, 45,8\% das exportações brasileiras de chapas de fibra prensada foram direcionadas para o mercado norte americano.

${ }^{23}$ Sistema Geral de Preferência 


\section{Gráfico 15 Principais países de destino das exportações brasileiras} de chapas de fibra em 1998

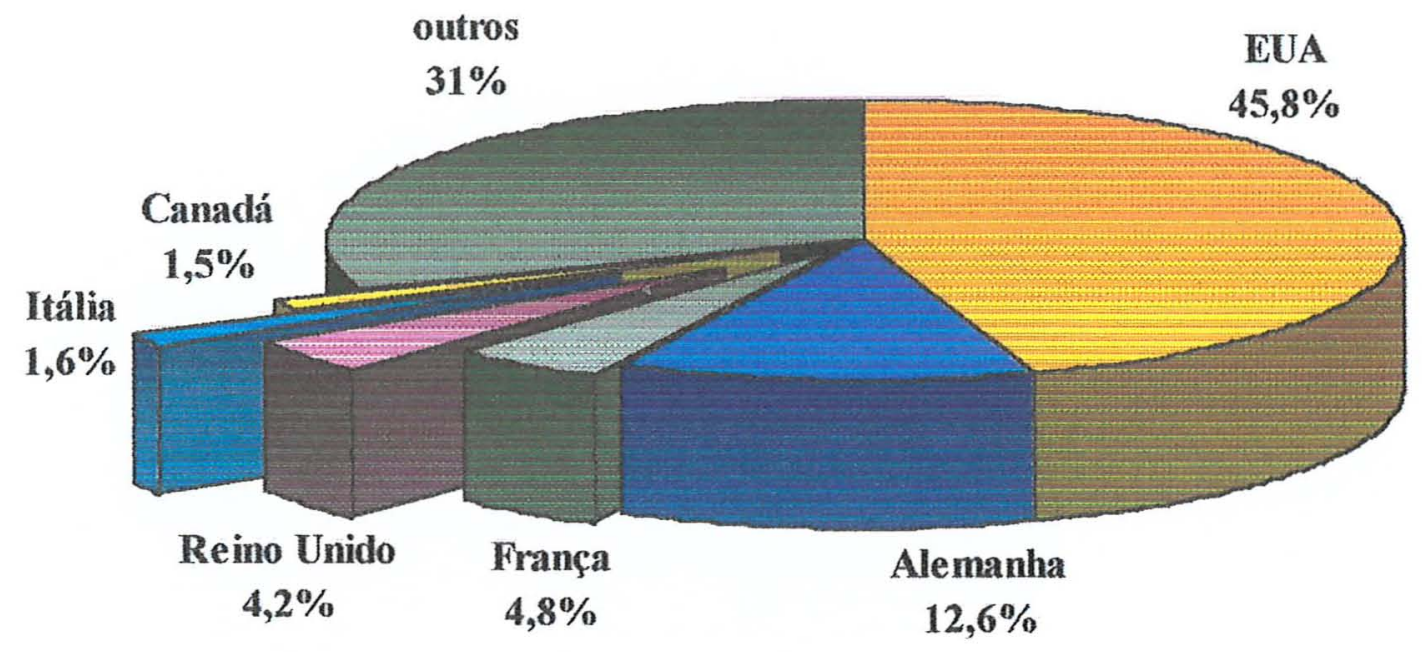

Fonte: home page da FAO (www.fao.org)

O Gráfico 16 mostra a evolução das exportações brasileiras de chapas de fibra prensada no período de 1961 a 1999. Como se pode observar, o comportamento do volume exportado até o início da década de 80 reflete o "boom" desses painéis no mercado externo. No período entre 1961 e 1980 as exportações brasileiras de chapas de fibra prensada cresceram, em média, $27 \%$ ao ano, contra apenas $3,8 \%$ da média mundial. 


\section{Gráfico 16 Evolução das exportações brasileiras de chapas de fibra prensada no período de 1961 a 1999}

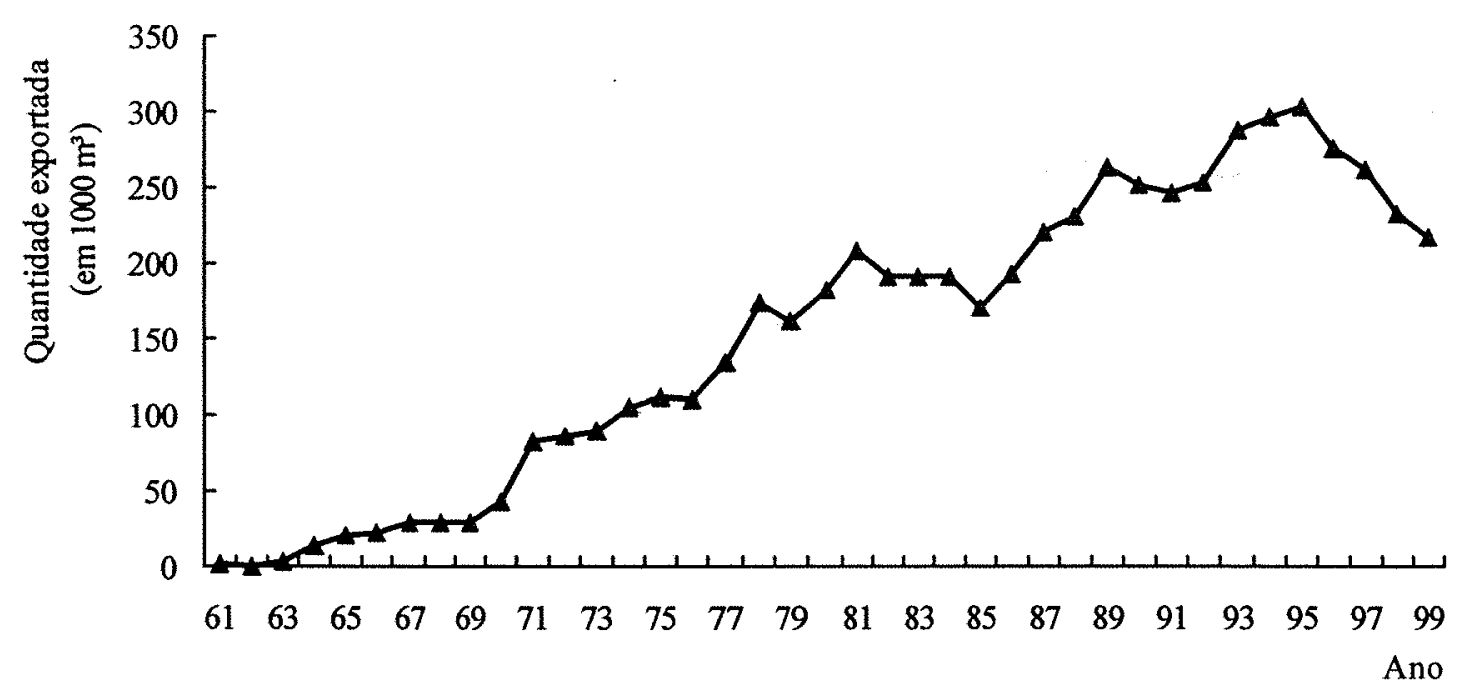

Fonte: home page da FAO (www.fao.org)

Contudo, a crise do mercado internacional na primeira metade dos anos 80 bem como o elevado protecionismo nos países consumidores, asseguraram um período com taxas de crescimento mais modestas, cerca de 3,7\% ao ano, até 1995 . A partir daí, as exportações brasileiras de chapas de fibra decresceram, em média, $8 \%$ ao ano. A valorização cambial brasileira ocorrida entre 1994 e 1998 explica, em parte, essa redução.

A partir da década de 80, o hardboard passou a enfrentar a concorrência do MDF, que vem invadindo diversos nichos de mercado daqueles painéis. Assim, é ilustrativo que, enquanto a produção doméstica americana de MDF cresceu $83 \%$ entre 1984 e 1993, a produção de hardboard decresceu $23 \%$.

A Tabela 7 mostra os maiores exportadores mundiais de chapas de fibra comprimida em anos selecionados. A primeira coisa que se observa são as elevadas taxas de crescimento das exportações desses países na década de 90 , a exceção do Brasil. Enquanto os países exportadores de MDF apresentam taxas de crescimento superiores a $20 \%$ ao ano, as exportações brasileiras caíram, em média, $1 \%$ ao ano 
(basicamente hardboard, uma vez que o país exportou apenas $17 \mathrm{mil} \mathrm{m}^{3}$ de $\mathrm{MDF}$ em 1999).

\section{Tabela 7}

Maiores exportadores mundiais de chapas de fibra comprimida em anos selecionados

(em mil m $\mathbf{~ m}^{3}$

\begin{tabular}{|c|c|c|c|c|c|}
\hline PaÍSES & 1980 & 1990 & 1995 & 1999 & $\begin{array}{r}\text { TAXA ANUAL DE } \\
\text { CRESCIMENTO } \\
(1990 \text { A 1999) }\end{array}$ \\
\hline Alemanha ${ }^{(11,8 \%)}$ & 36 & 45 & 226 & 1.090 & 36,1 \\
\hline Canadá (11\%) & 37 & 139 & 251 & 1.017 & 25,4 \\
\hline Malásia ${ }^{(9,4 \%)}$ & & & 251 & 872 & $57,4^{* *}$ \\
\hline França ${ }^{(6,3 \%)}$ & 65 & 94 & 393 & 586 & 21,7 \\
\hline Nova Zelândia ${ }^{(5,6 \%)}$ & 18 & 250 & 363 & 516 & 5,6 \\
\hline Bélgica Luxemburgo ${ }^{(5,3 \%)}$ & 10 & 29 & 31 & 487 & 45,2 \\
\hline Itália ${ }^{(4,1 \%)}$ & 12 & 176 & 309 & 383 & 12,2 \\
\hline Estados Unidos ${ }^{(3,8 \%)}$ & 28 & 163 & 616 & 347 & 7,4 \\
\hline Brasil $^{(2,4 \%)}$ & 183 & 252 & 303 & 217 & $(1,0)$ \\
\hline Outros & 1.086 & 1.346 & 2.212 & 3.733 & \\
\hline Total & 1.475 & 2.494 & 4.955 & 9.248 & 16,3 \\
\hline
\end{tabular}

Fonte: home page FAO (www.fao.org)

*Calculada pela autora, utilizando o antilogaritmo $(\delta)-1$, onde $\delta$ é o coeficiente da função $\log X=\alpha+\delta Y$ sendo $\mathrm{X}$ é o quantum exportado $\mathrm{e} \mathrm{Y}$ a variável tendência, medida na unidade da série, neste caso em anos.

**Referente ao período de 1992 a 1999.

Nota: Os números entre parênteses referem-se a participação de cada país no comércio mundial de chapas de fibra comprimida no ano de 1999. 
Em 1999, o Brasil detinha cerca de $2,3 \%$ do comércio mundial de chapas de fibra comprimida ( $7,5 \%$ se considerado apenas o hardboard), contra $12,4 \%$ em 1980, quando assumiu a liderança deste mercado.

É interessante comentar o crescimento de $57,4 \%$ ao ano das exportações da Malásia na década de 90, basicamente de MDF. Nesta década, esse país realizou maciços investimentos nesta indústria, o que aconteceu, principalmente, em função dos seus baixos custos de produção, sobretudo dos itens referentes a matéria-prima e salário. É ilustrativo, a este respeito, o estudo da Sunds Desfibrator, citado por Valença et a.l. (2000). A partir de uma estimativa dos custos de produção em algumas regiões do mundo para uma planta industrial de MDF, com capacidade aproximada de $110 \mathrm{mil} \mathrm{m}^{3}$ ao ano, o estudo conclui que a Europa possui o custo de produção mais elevado, $55 \%$ acima do verificado nos países do Sudeste da Ásia, devido, particularmente, ao alto custo da matéria-prima. O custo da madeira na Europa, por exemplo, é $112 \%$ maior que na Ásia. Já os Estados Unidos possuem custos cerca de $40 \%$ maiores que os da Ásia (o custo da mão-de-obra nos Estados Unidos é 300\% maior que na Ásia).

No caso do Brasil, os baixos custos de produção e a existência de um mercado local (a demanda interna, entre 1988 e 1996, aumentou a uma taxa média de $78 \%$ ao ano ${ }^{24}$ ) foram decisivos para a implantação das primeiras fábricas de MDF.

A produção nacional de MDF iniciou-se em setembro de 1997, quando entrou em operação a planta da Duratex em Agudos (SP). Foram produzidos naquele ano cerca de $30 \mathrm{mil} \mathrm{m}^{3}$ de MDF. Em agosto do ano seguinte, a Tafisa, empresa portuguesa pertencente ao grupo Sonae, concluiu a implantação de sua fábrica de MDF em Piên (PR). Em 1999 a produção brasileira de MDF atingiu $357 \mathrm{mil} \mathrm{m}^{3}$. Em dezembro de 2000, a chilena Masisa S.A. iniciou a produção de MDF em sua planta em Ponta Grossa (PR). Até o segundo semestre de 2001 deve entrar em operação a unidade de Jaguariaíva (PR) da Placas do Paraná S.A., empresa do grupo francês Louis Dreyfus. O

${ }^{24} \mathrm{~A}$ demanda interna, nesse período, pode ser considerada como equivalente à quantidade importada. 
Quadro 5 mostra a capacidade instalada prevista da indústria de MDF no Brasil ao final de 2001 .

Quadro 5

Capacidade instalada esperada para a indústria brasileira de MDF no final de 2001

\begin{tabular}{|l|c|c|}
\hline \multirow{2}{*}{ Empresa } & \multicolumn{2}{|c|}{ Capacidade Instalada } \\
\cline { 2 - 3 } & Mil $^{\mathbf{3}}$ ao ano & (\%) \\
\hline Duratex S.A. & 200 & 24,4 \\
\hline Tafisa Brasil S.A. & 160 & 19,5 \\
\hline Masisa do Brasil S.A. & 240 & 29,3 \\
\hline Placas do Paraná S.A.* & 220 & 26,8 \\
\hline Total & $\mathbf{8 2 0}$ & $\mathbf{1 0 0}$ \\
\hline
\end{tabular}

Fonte: ABIPA, citado por Valença et al. (2000) e fonte direta junto às empresas

*Início da produção previsto para o segundo semestre de 2001.

Constata-se, a partir dos dados do Quadro 5, que a indústria brasileira de MDF se caracteriza por um oligopólio altamente concentrado, mas sem empresas líderes.

Conforme se observa na Tabela 8 , a oferta nacional de MDF, que em quase sua totalidade é voltada para o mercado doméstico, vem substituindo as importações do produto. No período de 1997 a 1999, foram produzidos cerca de 554 mil $\mathrm{m}^{3}$ de $\mathrm{MDF}$, dos quais apenas $6,3 \%$ foram destinados ao mercado externo, principalmente para países da Europa. 


\section{Tabela 8}

Produção, importação, exportação e consumo aparente de MDF no Brasil no período de 1997 a 1999

$\left(\mathbf{m i l ~ m} \mathbf{m}^{3}\right)$

\begin{tabular}{lccc}
\hline Especificação & 1997 & 1998 & 1999 \\
\hline Produção & 30 & 167 & 357 \\
Importação & 113 & 35 & 11 \\
Exportação & 0 & 18 & 17 \\
Consumo Aparente & 143 & 184 & 351 \\
\hline
\end{tabular}

Fonte: ABIPA, citado por Valença et al. (2000)

Segundo Valença et al. (2000), as projeções de oferta e demanda de MDF indicam que, no periodo de 2000 a 2003, as empresas terão uma produção excedente de $860 \mathrm{mil} \mathrm{m}^{3}$, caso operem à plena capacidade, a qual poderá ser exportada. Contudo, deve ser observado que,

"(...) o excesso de capacidade é uma característica dessa indústria a exemplo do que vem ocorrendo a nível mundial. Em 1992, a capacidade das fábricas de MDF no mundo era de 8 milhões de $\mathrm{m}^{3}$ para uma demanda de 6 milhões. Em 1998, a capacidade passou para 24 milhões enquanto a demanda foi de 13 milhões. Dessa forma, a relação consumo/capacidade instalada correspondeu a $75 \%$ e $54 \%$ respectivamente. Assim, o excesso de capacidade projetado para o setor de MDF no Brasil deve ser compreendido segundo o posicionamento estratégico das empresas no mercado, uma vez que o produto apresenta alta rentabilidade e grande potencial de crescimento do consumo para os próximos anos".

O hardboard tem suas exportações concentradas em duas empresas, a saber, a Duratex e a Eucatex, responsáveis, em 1996, por 62\% e 38\%, respectivamente, das vendas brasileiras ao mercado externo. No entanto, Macedo et al. (1997) revelam as dificuldades crescentes dessas empresas, em meados da década de 90 , no sentido de obterem melhores preços para os seus produtos. 
É importante salientar o elevado nível tecnológico com o qual operam aquelas empresas. Para se ter uma idéia, a Eucatex possui duas das maiores prensas do mundo e também uma linha de pintura e secagem por meio de um processo inédito de ultravioleta com capacidade para pintar e secar 3,5 milhões de $\mathrm{m}^{3}$ de hardboard por mês. Além disso, por meio de melhoramento genético, principalmente na clonagem de eucalipto em suas plantações (aproximadamente 50 mil hectares entre pinus e eucalipto) a empresa consegue, em 6 anos, uma árvore de eucalipto com $30 \mathrm{~m}$ de altura e $28 \mathrm{~cm}$ de diâmetro. Pelos métodos tradicionais de plantio, uma árvore da mesma idade atinge pouco mais de $23 \mathrm{~m}$ de altura e $16 \mathrm{~cm}$ de diâmetro.

Sem dúvida a maior fragilidade das exportações brasileiras de chapas de fibra é a redução do tamanho do mercado do hardboard em todo o mundo, face às pressões ambientais e a concorrência do MDF. É ilustrativo a este respeito a afirmativa de Macedo et al. (1997, p.172),

"O maior mercado atendido pelo Brasil (Estados Unidos) vem reduzindo sistematicamente suas importações, o que mostra que as empresas brasileiras terão crescentes dificuldades para a colocação de seus produtos no exterior. Ao que tudo indica, a atuais exportações do Brasil para os Estados Unidos devem estar sendo direcionadas para aqueles nichos de mercado abandonados por empresas norteamericanas, em face das pressões ambientais relativas à fabricação do hardboard e/ou em decorrência de incorrerem em custos não competitivos com o MDF". 


\section{REFERÊNCIAL TEÓRICO E METODOLÓGICO}

Este capitulo inicia discutindo algumas hipóteses normalmente consideradas nos trabalhos econométricos a respeito da posição relativa de um país no mercado internacional e as elasticidades de oferta e demanda de exportações (item 3.1). No item seguinte (item 3.2) é especificado o modelo a ser utilizado nesta dissertação e no item 3.3 são discriminadas as fontes de dados a serem utilizadas.

\subsection{A hipótese sobre a posição relativa do país frente ao mercado internacional}

A análise econométrica dos determinantes do comportamento das exportações de um país tem sido realizada freqüentemente na literatura. As teorias do consumidor e da firma dão a estrutura teórica para a especificação das equações de exportação, indicando a existência de fatores que podem atuar tanto do lado da oferta quanto do da demanda de exportações.

A questão inicial a ser considerada na especificação das equações de exportação diz respeito à hipótese a ser adotada quanto a posição relativa do país frente ao mercado internacional. Os estudos mais tradicionais costumam levantar a hipótese de demanda de exportação infinitamente elástica, e a análise fica confinada à função de oferta de exportação. Trabalhos utilizando o argumento de país pequeno foram desenvolvidos por Doellinger et al. (1973), Cardoso e Dornbusch (1980), Lopes e Resende (1981), Musalem (1981), Tyler (1982), Angelo e Silva (1998), entre outros.

A hipótese do país pequeno, que se depara com uma função de demanda perfeitamente elástica, poderia parecer, a priori, uma opção plausivel para o presente estudo dada a pequena participação do Brasil no mercado internacional de 
produtos sólidos de madeira. $\mathrm{O}$ argumento parte do pressuposto de que o país pequeno oferta uma pequena parte da quantidade total do mercado, de modo que qualquer quantidade ofertada será vendida ao preço de mercado, ceteris paribus. Dessa forma, o país pequeno não pode influenciar o preço variando a quantidade ofertada.

No entanto, Brandt ${ }^{25}$, citado por Almeida e Mesquita (1995), alerta que no mundo real os ceteris nunca são paribus e a análise empirica da oferta ou da demanda deve tentar considerar explicitamente esses ceteris $^{26}$. A presença de restrições ao livre comércio, sobretudo as de natureza ambiental e comercial (como as discutidas no capítulo anterior), que descaracterizam a concorrência perfeita no mercado externo e a não homogeneidade dos produtos de madeira, parecem representativos dos fatores que tornam o pressuposto da curva de demanda horizontal questionável. Como observam Almeida e Mesquita (1995), se o produto não é homogêneo deve existir uma demanda específica pelo produto diferenciado de cada país, o que interfere na capacidade de formar preços e, portanto, na elasticidade-preço da demanda.

Reforçando este argumento, Braga e Markwald (1983) consideram que a própria lógica de garantir competitividade às exportações de produtos diferenciados, através da política cambial, implica possibilidade de redução de preços para aumentar as vendas.

Analogamente, a hipótese de oferta de exportação infinitamente preço-elástica (o que dispensaria a sua estimação empírica) também é criticável. Goldstein e Khan (1978) atentam para o fato de que, a menos que exista capacidade ociosa no setor exportador ou a produção para exportação seja sujeita a rendimentos de escala constantes ou crescentes, é improvável que um aumento na demanda mundial pelas exportações de um país possa ser satisfeita sem um aumento no preço, pelo menos a curto prazo.

\footnotetext{
${ }^{25}$ BRANDT, S.A. Comercialização agrícola. Piracicaba: Livroceres, 1980. 195p.

${ }^{26}$ Uma discussão detalhada sobre as relações entre o conceito de economia pequena e elasticidade-preço da demanda encontra-se em Almeida (1993) e Almeida e Mesquita (1995).
} 
Alguns trabalhos, entre eles o de Lemgruber (1976) e o de Carvalho e Haddad (1978), mesmo adotando a hipótese de país pequeno, incluem em suas equações a variável renda mundial, transformando essas equações em formas reduzidas de modelos não especificados. As formas reduzidas especificadas ad hoc, por sua vez, são passíveis de todas as críticas decorrentes da ausência de um modelo estrutural que permita a correta e precisa identificação dos parâmetros estimados por estas equações. Como observam Braga e Markwald (1983, p.708),

"(...) as equações relativas às exportações que incluem a variável renda mundial não são propriamente funções de oferta, porém formas reduzidas de modelos estruturais não especificados. Convém assinalar que essas construções teóricas implicam o abandono da hipótese de "país pequeno", uma vez que os modelos estruturais (implícitos) conteriam funções de demanda com elasticidade-preço finita".

Assim, supondo que a oferta e demanda das exportações brasileiras de produtos sólidos de madeira não são funções perfeitamente elásticas do preço, o tratamento mais adequado para sua determinação empírica parece ser a estimação de um modelo simultâneo. Os trabalhos de Goldstein e Khan (1978), Pinto (1980), Braga e Markwald (1983), Pinto (1983), Zini Júnior (1988), Portugal (1993), Amazonas e Barros (1995) e Angelo (1998) utilizam a abordagem simultânea.

\subsection{O modelo econométrico selecionado}

Os modelos de ajustamento do balanço de pagamentos, entre eles as abordagens das elasticidades e da absorção e o modelo IS/LM/BP, estabelecem relações entre o saldo da balança comercial, que aparece como variável dependente da equação, e um conjunto de variáveis macroeconômicas domésticas e externas ${ }^{27}$. Estes modelos são o referencial teórico para a escolha das variáveis explicativas que aparecem nas equações de oferta e demanda de exportações de um país.

\footnotetext{
${ }^{27}$ Para uma exposição detalhada sobre os modelos de ajustamento do setor externo ver, por exemplo, Almeida (1998), Branson \& Litvak (1979), Zini Júnior (1988) e Williamson (1989).
} 
A abordagem das elasticidades procura analisar o impacto, sobre o saldo da balança comercial, das variações dos preços relativos induzidas por uma desvalorização. Infere-se que uma desvalorização da taxa de câmbio deve reduzir os preços, em moeda estrangeira, dos bens exportados. Por outro lado, a desvalorização eleva os preços em moeda local dos bens importados. Em resposta a este movimento de preços relativos, as quantidades exportadas devem aumentar e as quantidades importadas devem diminuir.

A abordagem da absorção identifica a conta corrente (ou a balança comercial se as transações com serviços $\mathrm{e}$ as transferências unilaterais estão equilibradas), como sendo igual à diferença entre a produção nacional $(Y)$ e a absorção doméstica $^{28}(A)$. Utilizando $C A$ para designar o saldo em conta corrente, pode-se escrever que:

$$
\mathrm{CA}=\mathrm{Y}-\mathrm{A}
$$

Assim, se a produção ( $\mathrm{Y}$ ) excede a absorção (A), o saldo da balança (CA) comercial será positivo. Se o produto é inferior à absorção doméstica, o saldo será negativo.

O modelo IS/LM/BP, também denominado modelo keynesiano de economia aberta, incorporou as variáveis preço (da abordagem das elasticidades) e as variáveis renda (da abordagem da absorção) juntamente com a taxa de câmbio para explicar o ajustamento da balança comercial de um país ${ }^{29}$. As equações de exportação e de importação são definidas a seguir:

${ }^{28}$ Considera-se a seguinte igualdade entre produto (renda) e dispêndio:

$$
\mathrm{Y}=\mathrm{C}+\mathrm{I}+\mathrm{G}+\mathrm{X}-\mathrm{M}
$$

onde $\mathrm{Y}=$ produto (renda) $\mathrm{C}=$ consumo do setor privado, $\mathrm{I}=$ investimento do setor privado, $\mathrm{G}=$ gastos do governo, $X=$ exportações de bens e serviços e $M=$ importações de bens e serviços.

Supondo que as transações com serviços e as transferências unilaterais estão equilibradas e, considerando $C A=X-M$ e $A=C+I+G$, temos que:

$\mathrm{Y}=\mathrm{A}+\mathrm{CA}$ ou $\mathrm{CA}=\mathrm{Y}-\mathrm{A}$

sendo $\mathrm{CA}=$ saldo da balança comercial e $\mathrm{A}=$ absorção.

$29 \mathrm{Na}$ verdade, considera-se aqui apenas parte do modelo IS/LM/BP. A equação geral do modelo IS/LM/BP de determinação do saldo do balanço de pagamentos tem a seguinte especificação: 


$$
\begin{aligned}
& x=x\left(p, \varepsilon, y^{*}\right) \\
& m=m\left(p, p^{*}, \varepsilon, y\right)
\end{aligned}
$$

onde $\mathrm{x}$ são as exportações de bens e serviços; $\mathrm{m}$ são as importações de bens e serviços; $\mathrm{p}$ é o preço dos bens do país exportador; $\mathrm{p}^{*}$ é o preço externo dos bens que competem com os nacionais; $\varepsilon$ é a taxa de câmbio real; y é a renda real doméstica e $y^{*}$ é a renda real externa.

O raciocínio implícito nas equações (1), (2) e (3), juntamente com a análise realizada no capítulo 2, permitem definir as seguintes equações para a oferta $\mathrm{e}$ demanda de exportação de produtos sólidos de madeira ${ }^{30}$ :

$$
\begin{aligned}
& Q s_{t}^{i}=s\left(P X_{t}^{i}, E_{t}, U_{t}, Y_{t}^{i}\right) \\
& Q d_{t}^{i}=d\left(P X_{t}^{i}, P W_{t}^{i}, Y W_{t}^{i}\right)
\end{aligned}
$$

$\mathrm{O}$ sobreíndice $i$ indica cada produto sólido de madeira ou sua agregação. Assim, i pode indicar madeira serrada de coniferas, madeira serrada de não coníferas ou painéis à base de madeira.

Na função de oferta (4), $Q s_{t}^{i}$ representa a quantidade ofertada de exportações brasileiras do produto $i$ no momento $t . P X_{t}^{i}$ é o preço médio real em dólares das exportações brasileiras do produto $i$ no momento $t . E_{t}$ é taxa de câmbio efetiva real

$$
\mathrm{BP}=(\mathrm{X}-\mathrm{M})-\mathrm{F}-\mathrm{R}
$$

onde BP é o saldo do balanço de pagamentos, $X-M$ são as exportações líquidas de bens e serviços, $\mathrm{F}$ é a saída líquida de capital privado e R são as transferências a estrangeiros feitas pelo governo e pelo setor privado.

Para o propósito da presente pesquisa, os termos $\mathrm{F}$ e $\mathrm{R}$ são ignorados. Adicionalmente, supõe-se que as transações com serviços estão equilibradas. Assim, o balanço de pagamentos e a balança comercial são a mesma coisa.

${ }^{30}$ Observe que a equação (4) é muito próxima à equação (2), incluindo a variável $U_{t}$ que capta o raciocínio implícito na equação (1). A equação (5) é uma versão da equação (3) na ótica do país comprador do produto brasileiro. Assim, na equação (5) utiliza-se a renda estrangeira e o preço do produto exportado pelo Brasil e de seus concorrentes. 
no momento $t . U_{t}$ mede os efeitos cíclicos da demanda doméstica. $Y_{t}^{i}$ representa a produção efetiva do produto $i$ no momento $t$.

$\mathrm{Na}$ função de demanda (5), $Q d_{\imath}^{i}$ representa a quantidade demandada de exportações brasileiras do produto $i$ no momento $t$. $P W_{t}^{i}$ é o preço médio real em dólares das exportações mundiais do produto $i$ no momento $t$. YWW representa uma proxy para a renda mundial.

Cabe observar algumas questões no que concerne à escolha das variáveis explicativas nas equações de oferta e demanda de exportação de produtos sólidos de madeira. No que diz respeito à equação de oferta, a revisão da literatura mostra que, com poucas exceções, o efeito preço é avaliado levando-se em consideração os principais fatores que afetam a remuneração real do exportador. Os preços em dólares das exportações, a taxa de câmbio nominal, os subsídios à exportação e os preços domésticos são as variáveis relevantes neste caso ${ }^{31}$.

A inexistência de uma série relativa aos incentivos concedidos às exportações brasileiras de produtos sólidos de madeira, aliada a falta de um índice de preços doméstico apropriado para estes produtos levou-nos a considerar de modo separado o preço em dólar do produto exportado e a taxa de câmbio, a exemplo do que fizeram Parente (1990), Pessoa \& Lemos (1992) e Zini Júnior (1988).

$\mathrm{O}$ indice da taxa de câmbio efetiva real, $E t$, aqui utilizado usa como deflator o índice de preços por atacado (IPA) dos principais parceiros comerciais do Brasil no numerador e o IPA doméstico no denominador. Segundo Zini Júnior (1993), há diversos fatores a considerar sobre qual o índice de preços deve ser usado nas comparações da taxa de câmbio real. O índice de preços por atacado é, nesse sentido, o que reflete os preços praticados pelos produtores e acompanha principalmente os preços

\footnotetext{
${ }^{31}$ A formulação usual da taxa de rentabilidade real das exportações é dada pela multiplicação do índice de preços de exportação (PXt) pela taxa de câmbio nominal (Et) e por um indice de incentivo às exportações (St), dividido pelo índice de preços doméstico dos produtos exportados (PDt), ou seja: (PXt Et St) /PDt.
} 
de produtos industriais e de produtos agrícolas de grande safra (exportáveis). O IPA mostra, portanto, a evolução dos preços de bens que podem ser caracterizados como comercializáveis com o resto do mundo (tradeables).

A opção pelo conceito de taxa de câmbio efetiva real, em lugar da taxa de câmbio bilateral real, deu-se por ser o conceito "cesta de moeda", conforme Zini Júnior (1993), mais apropriado porque um país comercializa com vários parceiros, e a taxa de câmbio deve levar em conta o que ocorre com a média das relações de preços.

A variável utilização da capacidade produtiva, $U_{t}$, procura captar os efeitos cíclicos da demanda interna sobre as exportações. Se a demanda interna é alta em relação à capacidade produtiva, os bens são desviados das exportações para as vendas domésticas. Em sentido oposto, no caso de ser a demanda doméstica baixa, os produtores redirecionarão as vendas para o mercado externo, provocando um aumento na quantidade ofertada para exportação. Cardoso e Dornbusch (1980) acrescentam a hipótese de que o mercado interno pode ser considerado um "mercado cativo" onde a demanda é satisfeita com base em contratos implícitos de longo prazo, os quais não são diretamente afetados por variações de preço.

A inclusão de uma variável cíclica na equação de oferta se justifica por estar o consumo de produtos sólidos de madeira vinculado, basicamente, às indústrias moveleira, de embalagens e da construção civil, as quais são bastante sensíveis aos ciclos econômicos. Além disso, a variável utilização da capacidade produtiva permite avaliar a existência de significativa flexibilidade entre os mercados interno e externo.

$\mathrm{O}$ produto efetivo da indústria de desdobro mecânico dos produtos sólidos de madeira aqui considerados, $Y_{t}^{i}$, é utilizado como proxy para a capacidade produtiva destas indústrias, e o valor do seu coeficiente permite determinar a existência de um viés pró-exportação ou anti-exportação. Sob padrões normais de comércio, o sinal esperado deste coeficiente é positivo, ou seja, na medida em que cresce a produção, 
também cresce a oferta para os mercados doméstico e externo. O coeficiente maior que a unidade caracteriza um viés pró-exportação. Se o coeficiente for menor que a unidade o viés é anti-exportação fraco e se esse coeficiente for negativo, representa um viés anti-exportação forte. O crescimento do produto terá efeito neutro se, ceteris paribus, o crescimento das exportações ocorrer na mesma proporção do crescimento do produto. É esse, precisamente, o pressuposto implícito nos casos em que a variável dependente é definida como a razão quantum exportado/produto, conforme, por exemplo, Cardoso \& Dornbusch (1980), Rios (1987), Zini Júnior (1988), Zagury (1994).

É importante destacar que a escolha do produto efetivo como proxy da capacidade instalada deveu-se às dificuldades na obtenção de outras medidas dessa variável. Existem algumas metodologias de cálculo de relativa simplicidade, como o método da tendência, o qual assume taxa de crescimento fixa no tempo e outros métodos com taxa de crescimento variável, como o método de médias móveis ${ }^{32}$. Não obstante, suas aplicações estão condicionadas, na maioria das vezes, à determinação de anos em que ocorreram "picos" de produção, o que representou uma barreira para o cálculo das séries, dado que não se encontrou na literatura qualquer informação de anos de plena utilização da capacidade produtiva das indústrias de produtos sólidos de madeira.

Outra opção seria o cálculo do produto potencial a partir da linha de tendência do logarítmo de $Y_{t}^{i}$. Contudo, a construção da série através deste método não permite captar certas flutuações cíclicas no crescimento da capacidade, o que é questionável. Além disso, os modelos estimados utilizando a série de $Y_{t}^{i}$ obtida pela linha de tendência do logaritmo não apresentaram resultados econométricos satisfatórios. Desse modo, a exemplo de Cardoso e Dornbusch (1980) e Musalem (1981), optou-se por utilizar o produto efetivo como proxy do potencial produtivo.

Com relação a especificação da equação de demanda tomou-se a hipótese de que os produtos de madeira serrada e os painéis à base de madeira brasileiros

\footnotetext{
${ }^{32}$ Para uma discussão mais ampla a respeito do assunto ver Bonelli e Malan (1976), Neves (1978) e Zagury (1994).
} 
e seus competidores no mercado internacional não são substitutos perfeitos, o que parece um argumento bastante plausível, dado o elevado nível de agregação dos produtos considerados. Não obstante, mesmo se a composição das espécies agregadas fosse a mesma, a madeira importada de um país é dada como uma mercadoria diferente, simplesmente por causa da origem.

A variảvel preço relativo $\left(P X_{t}^{i} / P W_{t}^{i}\right)$ reflete a competitividade das exportações. Presume-se que os produtos sólidos de madeira provenientes de outros países constituem os principais concorrentes para os produtos brasileiros. Assim, um aumento nos preços de exportação do Brasil em relação ao preços de outros países exportadores resulta em uma queda na demanda externa pelo produto brasileiro. Por outro lado, o aumento dos preços de outros países exportadores em relação ao produto brasileiro incrementa a demanda externa por nossos produtos.

A variável $Y W_{t}$ representa os deslocamentos da demanda causados pelo crescimento da renda dos países importadores e pela expansão do comércio mundial de produtos sólidos de madeira. O efeito renda externa, na verdade um efeito "tamanho de mercado", engloba, ainda, fatores como mudanças nos gostos e padrões de uso dos consumidores, e alterações nos padrões de comércio. O quantum de exportações mundiais de produtos sólidos de madeira será usado como proxy da renda externa.

As equações (4) e (5) podem ser especificadas na forma log-linear conforme segue.

$$
\begin{aligned}
& \log Q s_{t}^{i^{*}}=\alpha_{0}+\alpha_{1} \log P X_{t}^{i}+\alpha_{2} \log E_{t}+\alpha_{3} \log U_{t}+\alpha_{4} \log Y_{t}^{i}+u_{t}^{s} \\
& \log Q d_{t}^{i^{*}}=\beta_{0}+\beta_{1} \log P X_{t}^{i} / P W_{t}^{i}+\beta_{2} \log Y W_{t}^{i}+u_{t}^{d}
\end{aligned}
$$

onde $u_{t}^{s}$ e $u_{t}^{d}$ são erros aleatórios.

A condição de equilíbrio a seguir completa o sistema: 


$$
\log Q_{t}^{i}=\log Q s_{t}^{i^{*}}=\log Q d_{t}^{i *}
$$

Os valores esperados para os parâmetros das equações de oferta e demanda de exportação são $\alpha_{1}>0, \alpha_{2}>0, \alpha_{3}<0, \beta_{1}<0, \beta_{2}>0$. Não se define $a$ priori $\alpha_{4}$.

O sistema especificado nas equações (6) e (7) supõe que o processo de ajustamento das quantidades ofertada e demandada se completa durante a unidade de tempo de observação. Não obstante, a dificuldade de informação perfeita no mercado, custos de adaptação, obrigações contratuais, etc. tornam questionável a hipótese de ajuste instantâneo e sugerem o uso dos chamados modelos de desequilibrio.

A hipótese de desequilíbrio aqui considerada é fornecida por Nerlove $^{33}$, citado em Gujarati (1995), no chamado modelo de ajustamento de estoque ou ajustamento parcial ${ }^{34}$. Supondo que a oferta e demanda por exportações brasileiras de madeira serrada e painéis à base de madeira se ajustam com uma defasagem, tem-se o seguinte mecanismo de ajustamento:

$$
\begin{aligned}
& \log Q_{t}^{i}-\log Q_{t-1}^{i}=\delta\left(\log Q s_{t}^{i^{*}}-\log Q_{t-1}^{i}\right) \\
& \log Q_{t}^{i}-\log Q_{t-1}^{i}=\gamma\left(\log Q d_{t}^{i *}-\log Q_{t-1}^{i}\right)
\end{aligned}
$$

onde $\delta$ e $\gamma$ são os coeficientes de ajustamento.

As equações (9) e (10) podem alternativamente serem escritas como:

\footnotetext{
${ }^{33}$ Nerlove, M. Distributed lags and demand analysis for agricultural and other commodities. Agricultural Handbook, n.14, jun. 1958.

${ }^{34}$ Outro procedimento para tratar modelos de desequilibrio é utilizado por Rios (1987), o qual ao envolver um esquema de máximo-minimo impöe uma séria perda de graus de liberdade. Adicionalmente, dividir as dados em observações que refletem excesso de demanda e excesso de oferta representa uma fonte de viés adicional. Goldstein e Khan (1978) sugerem um mecanismo no qual os preços se ajustam às condições de excesso de oferta e as quantidades às condições de excesso de demanda, o qual impõe uma série de restrições não lineares aos parâmetros das equações do modelo. Houthakker and Magee (1969) e Zini Júnior (1988) adotam a hipótese de ajustamento parcial.
} 


$$
\begin{aligned}
& \log Q_{t}^{i}=\delta \log Q s_{t}^{i^{*}}+(1-\delta) \log Q_{t-1}^{i} \\
& \log Q_{t}^{i}=\gamma \log Q d_{t}^{i^{*}}+(1-\gamma) \log Q_{t-1}^{i}
\end{aligned}
$$

Substituindo (6) e (7) em (11) e (12), obtêm-se as estruturas de oferta e demanda por exportações brasileiras de madeira serrada e painéis a base de madeira a serem estimadas:

$$
\begin{gathered}
\log Q_{t}^{i}=\varphi_{0}+\varphi_{1} \log P X_{t}^{i}+\varphi_{2} \log E_{t}+\varphi_{3} \log U_{t}+\varphi_{4} \log Y_{t}^{i} \\
+\varphi_{5} \log Q_{t-1}^{i}+\varepsilon_{t} \\
\log Q_{t}^{i}=\theta_{0}+\theta_{1} \log P X_{t}^{i} / P W_{t}^{i}+\theta_{2} \log Y W_{t}^{i}+\theta_{3} \log Q_{t-1}^{i}+\mu_{t}
\end{gathered}
$$

onde $\varepsilon_{t} \mathrm{e} \mu_{t}$ são erros aleatórios.

Os demais coeficientes são: $\varphi_{0}=\alpha_{0} \delta, \varphi_{1}=\alpha, \delta, \varphi_{2}=\alpha_{2} \delta$, $\varphi_{3}=\alpha_{3} \delta, \varphi_{4}=\alpha_{4} \delta, \varphi_{5}=(1-\delta), \theta_{0}=\beta_{0} \gamma, \theta_{1}=\beta_{1} \gamma, \theta_{2}=\beta_{2} \gamma, \theta_{3}=(1-\gamma)$.

Dado que $0<\delta<1$ e $0<\gamma<1$, os sinais esperados para os coeficientes das equações (13) e (14) são: $\varphi_{1}>0, \varphi_{2}>0, \varphi_{3}<0, \varphi_{5}>0, \theta_{1}<0, \theta_{2}>0$, $\theta_{3}>0$. Não se define, a priori, o sinal de $\varphi_{4}$.

A partir da utilização do modelo de ajustamento parcial constituído pelas equações (9), (10), (13) e (14) é possível distinguir entre elasticidade de curto prazo e de longo prazo. As elasticidades de curto prazo são os coeficientes estimados nas equações (13) e (14), as elasticidades de longo prazo são esses coeficientes divididos pelos respectivos coeficientes de ajustamento. 


\subsection{Fonte de dados}

As séries referentes à quantidade exportada de madeira serrada de coníferas, de madeira serrada de não coníferas e de painéis à base de madeira pelo Brasil $\left(Q_{t}^{i}\right)$ são fornecidas pela $\mathrm{FAO}$

O preço das exportações brasileiras de madeira serrada de coníferas e de não coniferas e de painéis à base de madeira $\left(P X_{t}^{i}\right)$ é aproximado pelo valor unitário das exportações. Este valor é calculado como o quociente entre os valores e quantidades exportadas de madeira serrada de coníferas e de não coníferas e de painéis à base de madeira. Os valores utilizados são os da FAO.

O preço das exportações mundiais de madeira serrada de coníferas, de madeira serrada de não coníferas e de painéis à base de madeira $\left(P W_{t}^{i}\right)$ é medido pelo valor unitário das exportações calculado como o quociente entre os valores e quantidades exportadas de madeira serrada de coníferas e não coníferas e de painéis à base de madeira. Esses dados também são da FAO.

A série de taxa de câmbio efetiva real $\left(E_{t}\right)$ foi construída a partir de duas fontes distintas: para o período de 1961/95 é utilizada a taxa de câmbio efetiva real calculada por Zini Júnior e disponível em Almeida (1998); a série é atualizada a partir da taxa de câmbio efetiva real fornecida pelo IPEA ${ }^{35}$.

$\mathrm{O}$ índice de preços por atacado (IPA) dos Estados Unidos, utilizado para transformar em valores reais as séries de preço, é do FMI, disponível em International Financial Statistics.

A variável cíclica $\left(U_{t}\right)$ é medida pela taxa de utilização da capacidade, correspondente à razão entre o produto interno bruto efetivo e o produto interno bruto potencial, calculada em Castro \& Cavalcanti (1998) e fornecida diretamente pelos

\footnotetext{
${ }^{35}$ A série de Almeida (1998) foi atualizada a partir das variações observadas na série do IPEA.
} 
autores. Os anos de 1998 e 1999 foram construídos a partir da variável uso da capacidade instalada calculada pela Fundação Getúlio Vargas (FGV) e disponível em Conjuntura Econômica ${ }^{36}$.

O produto efetivo $\left(Y_{t}^{i}\right)$, utilizado como proxy do produto potencial, corresponde as quantidades produzidas de madeira serrada de coníferas, de madeira serrada de não coníferas e painéis à base de madeira. Essas séries são da FAO.

O volume das exportações mundias é usado como proxy da renda mundial $\left(Y W_{i}^{i}\right)$. Os dados da quantidade de exportação são os calculados pela FAO.

Os dados acima referidos estão no Apêndice 1 .

${ }^{36}$ A série de Castro \& Cavalcanti (1998) foi atualizada a partir das variações observadas na série da FGV. 


\section{ESTIMATIVAS DAS EQUAÇÕES DE OFERTA E DEMANDA DE EXPORTAÇÃO DE PRODUTOS SÓLIDOS DE MADEIRA}

Este capitulo apresenta os resultados das estimativas das equações (13) e (14) para as exportações de madeira serrada (item 4.1) e para as exportações de painéis à base de madeira (item 4.2). Essas equações foram estimadas em sua forma estrutural $\mathrm{e}$ o método empregado na estimação foi o de mínimo quadrados em dois estágios.

4.1 Estimativas das equações de oferta e demanda de exportação de madeira serrada de coníferas e não coníferas

Conforme já observado no capítulo 2 do presente trabalho, entre 1961 e 1999, houve mudanças importantes na composição das exportações brasileiras de madeira serrada. Esse fato motivou a estimação de regressões separadas para as exportações brasileiras de madeira serrada das espécies coníferas e não coníferas.

\subsubsection{Estimativas das equações de oferta e demanda de exportação de madeira serrada de coníferas}

Até o início da década de 70, a Araucária angustifólia foi a principal espécie nas exportações brasileiras de madeira serrada. Com a exaustão das florestas nativas no sul do País, as exportações de madeira serrada de coníferas caíram sensivelmente até $1987^{37}$. A partir daí (em função das florestas de pinus implantadas com incentivos fiscais terem chegado a idade de corte), essas exportações cresceram, em média, $24,4 \%$ ao ano.

\footnotetext{
${ }^{37}$ No período entre 1961 e 1987 , as exportações brasileiras de madeira serrada de coníferas caíram, em média $11,7 \%$ ao ano.
} 
O Gráfico 4, no capítulo 2, ilustra a existência de dois períodos distintos na evolução das exportações de madeira serrada de coníferas, quais sejam, 1961 a 1987 e 1988 a 1999. O ano de 1987 é de inflexão na curva de evolução das exportações de madeira serrada de coníferas.

Com o propósito de testar estatisticamente se houve esta "quebra" de tendência fez-se uso do ajustamento de uma poligonal (Hoffmann \& Vieira, 1987). Como observam os autores, o ajuste da poligonal com um vértice pode ser feito utilizando duas variáveis artificiais, $V_{t}$ e $W_{t}$, uma para representar o correr do tempo no primeiro período, e outra para representar o correr do tempo no segundo período, no qual a tendência da variável dependente seria diferente.

O modelo estatístico em questão é

$Y_{t}=\alpha+\beta_{1} V_{t}+\beta_{2} W_{t}+u_{t}$

Onde

$Y_{t}$ é a variável dependente, neste caso, a quantidade exportada de madeira serrada de coniferas;

$W_{t}=Z_{t}\left(X_{t}-K\right)$

$V_{t}=\left(1-Z_{t}\right)\left(X_{t}-K\right)$

Sendo

$Z_{t} \quad\left\{\begin{array}{l}=0 \text { quando } X_{t}<K \\ =1 \text { quando } X_{t} \geq K\end{array}\right.$

$K$ é o ano de inflexão, no caso 1987 ;

$X_{t}$ é o ano de cada observação;

$u_{t}$ é o erro aleatório. 
O modelo acima especificado foi estimado pelo método de mínimos quadrados ordinários, obtendo-se a seguinte regressão (onde os valores entre parênteses correspondem às estatísticas $t$ de Student, e as letra "a" e "ns" representam coeficientes de regressão estatisticamente significativos a $1 \%$ e não significativos, respectivamente)

$$
\begin{gathered}
Q_{t}=-70234,816-52096,736 V_{t}+63207,898 W_{t}+u_{t} \\
(-1,251)^{\mathrm{ns}} \quad(-12,828)^{\mathrm{a}} \quad(7,223)^{\mathrm{a}} \\
\mathrm{R}^{2}=0,821 \quad \mathrm{~F}=82,3182 \quad \mathrm{~d}=0,567
\end{gathered}
$$

A fim de verificar se a mudança na tendência da série é estatisticamente diferente de zero, testou-se a hipótese $H_{0}: \beta_{2}=\beta_{1}\left(H_{0}: \beta_{2}-\beta_{1}=0\right)$. 0 valor crítico de $t$ para um teste bilateral, ao nível de significância de $1 \%$ e com 36 graus de liberdade, é 2,750 . O valor de $t$ calculado $^{38}$ é 9,950. Portanto, pode-se afirmar que, estatisticamente, a série tem quebra de tendência em 1987.

Diante desse resultado, optou-se pela estimação das equações de oferta e demanda de exportações de madeira serrada de coníferas para dois períodos distintos, a saber, 1961/87 e 1988/99. As Tabelas 9 e 10 sumariam essas estimativas.

${ }^{38}$ Onde $t=\frac{\beta_{2}-\beta_{1}}{\sqrt{V\left(\beta_{2}\right)+V\left(\beta_{1}\right)-2 \operatorname{cov}\left(\beta_{1}-\beta_{2}\right)}}$ 
Tabela 9

Estimativa das equações estruturais da oferta de exportação de madeira serrada de coníferas

\begin{tabular}{|c|c|c|c|c|c|c|c|c|c|}
\hline \multirow[t]{2}{*}{ Período } & \multicolumn{6}{|c|}{ Variáveis } & \multirow{2}{*}{$\mathbf{R}^{2}$} & \multirow{2}{*}{$\mathbf{F}$} & \multirow{2}{*}{$\mathbf{h}^{*}$} \\
\hline & Constante & $\mathrm{PX}_{\mathrm{t}}$ & $\mathrm{E}_{\mathfrak{t}}$ & $\mathrm{U}_{\mathrm{t}}$ & $Y_{t}$ & $\mathrm{Q}_{\mathrm{t}-1}$ & & & \\
\hline 1961 a 1987 & $\begin{array}{c}5,824 \\
(0,723)^{\mathrm{ns}}\end{array}$ & $\begin{array}{c}-0,101 \\
(-0,291)^{\mathrm{ns}}\end{array}$ & $\begin{array}{c}0,330 \\
(0,435)^{\mathrm{ns}}\end{array}$ & $\begin{array}{c}-0,587 \\
(-0,668)^{\mathrm{ns}}\end{array}$ & $\begin{array}{c}-0,228 \\
(-0,668)^{\mathrm{ns}}\end{array}$ & $\begin{array}{c}0,946 \\
(7,158)^{\mathrm{a}}\end{array}$ & 0,965 & 110,715 & $-0,387$ \\
\hline 1988 a 1999 & $\begin{array}{c}69,429 \\
(0,169)^{\mathrm{ns}}\end{array}$ & $\begin{array}{c}3,410 \\
(0,522)^{\mathrm{ns}}\end{array}$ & $\begin{array}{c}2,135 \\
(1,063)^{\mathrm{ns}}\end{array}$ & $\begin{array}{c}-5,156 \\
(-0,533)^{\mathrm{ns}}\end{array}$ & $\begin{array}{c}-1,157 \\
(-0,192)^{\mathrm{ns}}\end{array}$ & $\begin{array}{c}1,732 \\
(1,256)^{\text {ns }}\end{array}$ & 0,905 & 11,466 & - \\
\hline
\end{tabular}

Notas: Os números entre parênteses sob os coeficientes são as estatísticas $t$; onde "a" representa significativo ao nível de $1 \%$ e "ns" não significativo.

*A estatística $h$ é um teste de correlação serial de primeira ordem em modelos auto-regressivos. A regra de decisão é: se $h>1,96$, rejeita-se a hipótese nula de que não há autocorrelação positiva de primeira ordem; se $\mathrm{h}<-1,96$, rejeita-se a hipótese nula de que não há autocorrelação negativa de primeira ordem; e se $\mathrm{h}$ se encontra entre -1,96 e 1,96, não se rejeita a hipótese nula de que não há autocorrelação de primeira ordem. O teste não é aplicável se [n var $\left(\alpha_{2}\right)$ ] superar 1 , sendo $n$ o número de observações e var( $\left(\alpha_{2}\right)$ a variância da estimativa do parâmetro da variável dependente defasada (Gujarati, 1995).

Tabela 10

Estimativa das equações estruturais da demanda de exportação de madeira serrada de coníferas

\begin{tabular}{lcccccccc}
\hline \multirow{2}{*}{ Período } & \multicolumn{9}{c}{ Variáveis } & \multirow{2}{c}{$\mathbf{R}^{2}$} & $\mathbf{F}$ & $\mathbf{h}^{*}$ \\
\cline { 2 - 7 } & Constante & $\mathrm{PX}_{\mathrm{t}} / \mathrm{PW}_{\mathrm{t}}$ & $\mathrm{YW}_{\mathrm{t}}$ & $\mathrm{Q}_{\mathrm{t}-1}$ & & & \\
\hline \multirow{2}{*}{1961 a 1987 } & $-2,995$ & $-0,589$ & 0,264 & 0,889 & 0,974 & 270,360 & $-1,063$ \\
& $(-0,406)^{\mathrm{ns}}$ & $(-1,603)^{\mathrm{c}}$ & $(0,652)^{\mathrm{ns}}$ & $(9,361)^{\mathrm{a}}$ & & & \\
\hline \multirow{2}{*}{1988 a 1999 } & $-18,686$ & 0,754 & 1,131 & 0,840 & 0,883 & 20,214 & - \\
& $(-0,513)^{\mathrm{ns}}$ & $(0,848)^{\mathrm{ns}}$ & $(0,505)^{\mathrm{ns}}$ & $(2,207)^{\mathrm{b}}$ & & & \\
\hline
\end{tabular}

Notas: Os números entre parênteses sob os coeficientes são as estatísticas $t$; onde " $\mathrm{a}$ " representa significativo ao nível de $1 \%$, "b" significativo ao nível de $5 \%$, "c" significativo até $20 \%$ e "ns" não significativo.

*A estatística $h$ é um teste de correlação serial de primeira ordem em modelos auto-regressivos. A regra de decisão é: $\mathrm{se} h>1,96$, rejeita-se a hipótese nula de que nao há autocorrelação positiva de primeira ordem; se $\mathrm{h}<-1,96$, rejeita-se a hipótese nula de que não há autocorrelação negativa de primeira ordem; e se $\mathrm{h}$ se encontra entre -1,96 e 1,96, não se rejeita a hipótese nula de que não há autocorrelação de primeira ordem. O teste não é aplicável se [n var $\left(\alpha_{2}\right)$ ] superar 1 , sendo n o número de observações e var $\left(\alpha_{2}\right)$ a variância da estimativa do parâmetro da variável dependente defasada (Gujarati, 1995). 
Como se observa, as regressões estimadas, de modo geral, não mostram bom ajustamento aos dados. Na equação de oferta do primeiro período, o coeficiente da variável preço apresenta sinal contrário ao esperado a priori. Os outros parâmetros estimados têm seus sinais esperados mas não são significativamente diferentes de zero (a exceção da variável $Q_{t-1}$, que é significativa ao nível de $1 \%$ ).

O mesmo se verifica nas estimativas da oferta para o segundo período. Os coeficientes estimados apresentam os sinais esperados, mas não são estatisticamente significativos. Contudo, o coeficientes de determinação $\left(\mathrm{R}^{2}\right)$ das duas equações são elevados.

No que diz respeito às regressões para a demanda de exportação de madeira serrada de coniferas, o parâmetro estimado para a variável preço é significativo apenas no primeiro periodo. O baixo valor deste parâmetro $(-0,589)$ sugere que a demanda por exportação de madeira serrada de coníferas é inelástica com relação a variações no preço.

Já os coeficientes estimados para a variável renda não são significativamente diferentes de zero em nenhum dos subperíodos. Estes resultados indicam que o tamanho do mercado não foi um fator limitativo ao crescimento das exportações brasileiras de madeira serrada de coníferas durante o período analisado.

Finalmente, as estimativas do parâmetro relativo à variável dependente defasada é de 0,889 no período $1961 / 87$, e de 0,840 no período $1988 / 99$. Estas estimativas são estatisticamente significativas nos dois casos.

Novamente, as regressões ajustadas para a demanda por exportações brasileiras de madeira serrada de coníferas apresentam elevado poder explicativo, o que pode ser avaliado através do valor do coeficiente de determinação $\mathrm{R}^{2}$. Assim, 97,4\% das variações observadas na quantidade de madeira serrada de coníferas exportada pelo Brasil, no período entre 1961 e 1987, são explicadas por variações nas variáveis independentes. Esta percentagem é de $88,3 \%$ no segundo período. 
Porém, conforme observa Gujarati (1995), $\mathrm{R}^{2}$ alto e poucas razões $t$ significativas é um "clássico" sintoma de multicolinearidade (também refletida em coeficientes de correlação simples elevados entre alguns pares de variáveis). Outro problema, também de ordem empírica, diz respeito aos poucos graus de liberdade na estimação, sobretudo para o segundo período.

No que tange a multicolinearidade, não foi possível aplicar nenhum dos métodos convencionais de correção. Não havia informação a priori sobre os parâmetros, nem a possibilidade de eliminar variáveis sem incorrer em erro, possivelmente mais sério, de especificação ${ }^{39}$.

Cabe, ainda, uma última observação no que tange as características do mercado de madeira serrada de coníferas. Como já discutido no capítulo 2 , a inserção do Brasil no comércio internacional de madeiras serradas de coníferas esteve, inicialmente, intimamente associada com as reservas de pinheiras do Paraná e com o processo de expansão da agropecuária. Assim, a oferta de madeira serrada de pinho estava associada à atividade extrativa. Isto fez a indústria de madeira serrada ser uma atividade com características próprias, cuja variável relevante do lado da oferta foi, sem dúvida, a disponibilidade de matéria-prima.

\subsubsection{Estimativas das equações de oferta e demanda de exportação de madeira serrada de não coníferas}

No presente item, são apresentados os resultados das regressões estimadas para as exportações brasileiras de madeira serrada de não coníferas para o período entre 1970 e 1999. O período de 1961 a 1969 é retirado da análise devido à pequena quantidade exportada de não coníferas nesses anos ${ }^{40}$.

\footnotetext{
${ }^{39} \mathrm{E}$ importante salientar que a exclusão de algumas variáveis não melhorou as estimativas (ver Apêndice 3). Assim as variáveis não significativas são mantidas no modelo para preservar a coerência teórica.

40 Em 1961, por exemplo, as madeiras serradas de não coníferas representavam menos de $2 \%$ das exportações totais de madeira serrada.
} 
As equaç̃̃es (13) e (14), apresentadas no capítulo 3, foram utilizadas para as estimativas. A única alteração é a exclusão da variável $U_{t}$ na equação de oferta. Como foi visto no capítulo 2 , o mercado internacional absorve menos de $10 \%$ das cerca de 400 espécies de não coníferas comerciáveis. Assim, não há flexibilidade entre 0 mercado doméstico e o mercado externo (ou ao menos esta flexibilidade pode ser considerada desprezível). Além disso, do ponto de vista empírico, a exclusão de $U_{t}$ melhorou significativamente os resultados, dada a alta correlação entre aquela variável e $Y_{t}$ (ver Apêndices 2 e 3).

As Tabelas 11 e 12 trazem os resultados das estimativas das estruturas de oferta e demanda de exportação de madeira serrada de não coníferas.

Tabela 11

Estimativa da equação estrutural da oferta de exportação de madeira serrada de não coníferas para o período de 1970 a 1999

\begin{tabular}{|c|c|c|c|c|c|c|c|}
\hline \multicolumn{5}{|c|}{ Variáveis } & \multirow{2}{*}{$\mathbf{R}^{2}$} & \multirow{2}{*}{$\mathbf{F}$} & \multirow{2}{*}{$\mathbf{h}^{*}$} \\
\hline Constante & $\mathrm{PX}_{\mathrm{t}}$ & $\mathrm{E}_{t}$ & $Y_{t}$ & $\mathrm{Q}_{\mathrm{t}-1}$ & & & \\
\hline 5,927 & 1,757 & $-0,692$ & $-0,498$ & 0,653 & 0,773 & 21,328 & 0,755 \\
\hline$(1,898)^{\mathrm{c}}$ & $(2,098)^{b}$ & $(-2,063)^{b}$ & $(-1,237)^{\mathrm{ns}}$ & $(3,976)^{\mathrm{a}}$ & & & \\
\hline
\end{tabular}

Notas: Os números entre parênteses sob os coeficientes são as estatísticas $t$; onde "a" representa significativo ao nível de $1 \%$, "b" significativo ao nível de $5 \%$, "c" significativo até $20 \%$ e "ns" não significativo.

* A estatística h é um teste de correlação serial de primeira ordem em modelos auto-regressivos. A regra de decisão é: $s e \mathrm{~h}>1,96$, rejeita-se a hipótese nula de que não há autocorrelação positiva de primeira ordem; se $\mathrm{h}<-1,96$, rejeita-se a hipótese nula de que não há autocorrelação negativa de primeira ordem; e se h se encontra entre -1,96 e 1,96, não se rejeita a hipótese nula de que não há autocorrelação de primeira ordem. 
Tabela 12

Estimativa da equação estrutural da demanda de exportação de madeira serrada de não coníferas para o período de 1970 a 1999

\begin{tabular}{|c|c|c|c|c|c|c|}
\hline \multicolumn{4}{|c|}{ Variáveis } & \multirow{2}{*}{$\mathbf{R}^{2}$} & \multirow{2}{*}{$\mathbf{F}$} & \multirow{2}{*}{$\mathbf{h}^{*}$} \\
\hline Constante & $\mathrm{PX} / \mathrm{PW}$ & $\mathrm{YW}_{\mathrm{t}}$ & $Q_{t-1}$ & & & \\
\hline$-6,036$ & $-0,182$ & 0,836 & 0,412 & 0,878 & 62,259 & 2,040 \\
\hline$(-2,553)^{\mathrm{a}}$ & $(-0,809)^{\mathrm{ns}}$ & $(4,029)^{\mathrm{a}}$ & $(3,704)^{\mathrm{a}}$ & & & \\
\hline
\end{tabular}

Notas: Os números entre parênteses sob os coeficientes são as estatísticas $t$; onde "a" representa significativo ao nível de $1 \%$, "b" significativo ao nível de $5 \%$ e "ns" não significativo.

* A estatística h é um teste de correlação serial de primeira ordem em modelos auto-regressivos. A regra de decisão é: se $h>1,96$, rejeita-se a hipótese nula de que não há autocorrelação positiva de primeira ordem; se $\mathrm{h}<-1,96$, rejeita-se a hipótese nula de que não há autocorrelação negativa de primeira ordem; e se h se encontra entre -1,96 e 1,96, não se rejeita a hipótese nula de que não há autocorrelação de primeira ordem.

As estimativas da equação de oferta são satisfatórias. Os coeficientes das variáveis apresentam os sinais esperados, à exceção da variável $E_{t}$, e são estatisticamente significativos ao nível de $5 \%$ (o coeficiente da variável $Y_{t}$ é significativo apenas ao nível de $22 \%$ ).

A elasticidade-preço da oferta de curto prazo é 1,757, o que sugere que a oferta de exportação de madeira serrada de não coníferas é elástica com relação a variações no preço. Assim, uma variação de $10 \%$ no preço externo, ceteris paribus, conduz a uma variação no mesmo sentido de, aproximadamente, $17,6 \%$ na quantidade exportada de madeira serrada de não coniferas $^{41}$.

\footnotetext{
${ }^{41}$ Angelo (1998) obteve elasticidade-preço de oferta de 0,541 para as madeiras tropicais. No entanto, a variável preço nesse caso foi medida em termos de lucratividade do exportador, como discutido no capítulo 3 do presente trabalho, incorporando (entre outras variáveis) os subsídios às exportações de manufaturados na construção do índice, o que pode ter viesado para baixo o coeficiente estimado, uma vez que nada assegura que o setor foi beneficiado pelos subsídios destinados aos manufaturados em geral. Já Angelo \& Silva (1998) obtiveram elasticidade-preço da ordem de 1,19 para a oferta de mogno, também usando o conceito de lucratividade mencionado.
} 
O coeficiente da variável $Y_{t}$ indica a existência de um viés anti-exportação forte, o que não causa surpresa, dado o elevado nível de agregação do que se chamou "madeira serrada de não coníferas". Como já discutido, as madeiras tropicais enfrentam fortes restrições no mercado internacional. Além disso, os consumidores são cautelosos quanto ao consumo de novas espécies. Assim, um aumento na produção pode significar queda na quantidade exportada, se a composição das espécies produzidas não atender às preferências do mercado externo.

A esse respeito, é importante frisar que as espécies de maior valor comercial, como o mogno e a virola, tiveram sua produção sensivelmente reduzida durante o período analisado, ao passo que os planos de manejo sustentado na Amazônia viabilizaram a exploração de diversas espécies arbóreas até então desconhecidas do mercado.

O coeficiente estimado da variável dependente defasada é significativo ao nível de $1 \%$ e o seu valor estimado é 0,653 . Isto dá um coeficiente de ajustamento de 0,347 .

As estimativas dos parâmetros da equação de demanda são também bastante satisfatórias. Apenas o coeficiente de $P X_{t} / P W_{t}$, embora com o sinal esperado, é estatisticamente nulo. A elasticidade-preço de curto prazo é $-0,182$ e indica que a demanda externa por exportações brasileiras de madeira serrada de não coníferas é inelástica com relação ao preço. Assim, a hipótese de que o Brasil enfrenta uma curva de demanda com elasticidade-preço infinita não parece adequada, uma vez que esta elasticidade não apresenta valor elevado.

O coeficiente encontrado para a variável renda externa é significativo ao nivel de $1 \%$. Este coeficiente revela que, mantendo-se tudo o mais constante, uma variação de $10 \%$ no comércio mundial de madeira serrada de não coníferas, tende a causar uma variação, no mesmo sentido, de aproximadamente, $8,36 \%$ na quantidade exportada de madeira serrada de não coníferas pelo Brasil. 
A variável dependente defasada é significativa ao nível de $1 \%$ e seu valor estimado é de 0,412 .

Como se pode inferir dos valores assumidos pelo coeficiente de determinação $\left(\mathrm{R}^{2}\right)$, as estruturas de oferta $\mathrm{e}$ demanda propostas constituem especificações bastante representativas do comportamento das exportações brasileiras de madeira serrada de coniferas.

\subsection{Estimativas das equações de oferta e demanda de exportação de painéis à base de madeira}

O modelo utilizado para a estimação das estruturas de oferta e demanda de exportação de painéis à base de madeira é uma versão restrita do modelo proposto no capítulo 3. A especificação atual restringe o coeficiente do produto, $Y_{t}$, à unidade, de modo que a variável dependente na equação de oferta passa a ser a razão entre $Q_{t}$ e $Y_{t}$. Isso corresponde a assumir que as firmas mantêm uma certa capacidade planejada para suprir os mercados externos. Funções de exportação usando esta restrição foram estimadas por Cardoso \& Dornbusch (1980), Rios (1987), Zini Júnior (1988), Zagury (1994), entre outros ${ }^{42}$.

Os resultados das regressões estimadas são apresentados nas Tabelas 13 e 14. O modelo proposto gerou coeficientes estatisticamente significativos para ambas as equações. Os sinais dos coeficientes (à exceção da variável $E_{t}$ ) estão de acordo com o esperado teoricamente.

\footnotetext{
${ }^{42}$ A equação de oferta com a variável dependente assim redefinida tem uma interpretação não-ambígua apenas quando o coeficiente da variável $Y_{t}$ é igual a um na equação não-restrita. Se isto se dá, a divisão de $Q_{t}$ por $Y_{t}$ não afeta a interpretação dos demais coeficientes. A hipótese de que $\varphi_{4}, 0$ coeficiente da variável $Y_{t}$ na equação não-restrita, é igual a um não foi rejeitada ao nível de $1 \%$ (ver Gurarati, 1995, p.293). A estimativa da especificação não-restrita está no Apêndice 3.
} 
Tabela 13

Estimativa da equação estrutural da oferta de exportação de painéis à base de madeira para o período de 1961 a 1999

\begin{tabular}{cccccccc}
\hline \multicolumn{5}{c}{ Variáveis } & $\mathbf{R}^{2}$ & $\mathbf{F}$ & $\mathbf{h}^{*}$ \\
\cline { 1 - 7 } Constante & $\mathrm{PX}_{\mathrm{t}}$ & $\mathrm{E}_{\mathrm{t}}$ & $\mathrm{U}_{\mathrm{t}}$ & $\mathrm{Q}_{\mathrm{t}-1}$ & & & \\
\hline 3,540 & 1,311 & $-0,599$ & $-3,368$ & 0,355 & 0,812 & 35,668 & 2,093 \\
$(1,090)^{\mathrm{ns}}$ & $(1,680)^{\mathrm{c}}$ & $(-2,560)^{\mathrm{a}}$ & $(-2,132)^{\mathrm{b}}$ & $(8,671)^{\mathrm{a}}$ & & &
\end{tabular}

Notas: Os números entre parênteses sob os coeficientes são as estatísticas $t$; onde "a" representa significativo ao nível de $1 \%$ " $b$ " significativo ao nível de $5 \%$, "c" significativo até $20 \%$ e "ns" não significativamente diferente de zero.

*A estatística h é um teste de correlação serial de primeira ordem em modelos auto-regressivos. A regra de decisão é: se $\mathrm{h}>1,96$, rejeita-se a hipótese nula de que não há autocorrelação positiva de primeira ordem; se $h<-1,96$, rejeita-se a hipótese nula de que não há autocorrelação negativa de primeira ordem; e se h se encontra entre -1,96 e 1,96, não se rejeita a hipótese nula de que não há autocorrelação de primeira ordem.

\section{Tabela 14}

Estimativa da equação estrutural da demanda de exportação de painéis à base de madeira para o período de 1961 a 1999

\begin{tabular}{|c|c|c|c|c|c|c|}
\hline \multicolumn{4}{|c|}{ Variáveis } & \multirow{2}{*}{$\mathbf{R}^{2}$} & \multirow{2}{*}{\multicolumn{2}{|c|}{$\mathbf{F}$}} \\
\hline Constante & $\mathrm{PX}_{\mathrm{t}} / \mathrm{PW}_{\mathrm{t}}$ & $\mathrm{YW}_{\mathrm{t}}$ & $Q_{t-1}$ & & & \\
\hline$-3,191$ & $-0,148$ & 0,387 & 0,749 & 0,980 & 551,870 & 2,740 \\
\hline$(-1,624)^{\mathrm{c}}$ & $(-0,809)^{\mathrm{ns}}$ & $(2,034)^{b}$ & $(7,294)^{\mathrm{a}}$ & & & \\
\hline \multicolumn{7}{|c|}{$\begin{array}{l}\text { Notas: Os números entre parênteses sob os coeficientes são as estatísticas } t \text {; onde "a" representa } \\
\text { significativo ao nível de } 1 \% \text {, "b" significativo ao nível de } 5 \% \text {, "c" significativo até } 20 \% \text { e "ns" não } \\
\text { significativo. } \\
\text { *A estatística } h \text { é um teste de correlação serial de primeira ordem em modelos auto-regressivos. A regra de } \\
\text { decisão é: se } h>1,96 \text {, rejeita-se a hipótese nula de que não há autocorrelação positiva de primeira ordem; } \\
\text { se } h<-1,96 \text {, rejeita-se a hipótese nula de que não há autocorrelação negativa de primeira ordem; e se h se } \\
\text { encontra entre }-1,96 \text { e } 1,96 \text {, não se rejeita a hipótese nula de que não há autocorrelação de primeira ordem. } \\
\text { O teste não é aplicável se [n var }\left(\alpha_{2}\right) \text { ] superar } 1 \text {, sendo n o número de observações e var }\left(\alpha_{2}\right) \text { a variância da } \\
\text { estimativa do parâmetro da variável dependente defasada.(Gujarati, 1995) }\end{array}$} \\
\hline
\end{tabular}


A elasticidade-preço da oferta, de 1,311, indica que a oferta de exportação de painéis à base de madeira é elástica com relação aos preços. Assim, uma variação de $10 \%$ nos preços externos, ceteris paribus, conduz a uma variação, no mesmo sentido, de aproximadamente $13 \%$ na quantidade ofertada.

A estimativa do parâmetro relativo à variável taxa de câmbio real é significativo ao nível de $1 \%$, mas tem sinal contrário ao esperado a priori.

O coeficiente do indice de atividade cíclica $(-3,368)$ é estatisticamente significativo ao nível de $5 \%$. Assim, a hipótese de que quando o mercado interno se aquece a oferta de painéis à base de madeira cai não é rejeitada ${ }^{43}$.

O coeficiente da variável dependente defasada é significativo nas equações de oferta e demanda e seus valores estimados são 0,355 e 0,749 , respectivamente. Isso dá um coeficiente de ajuste de, aproximadamente, 0,645 e 0,251, respectivamente.

$\mathrm{Na}$ equação de demanda, o coeficiente associado a variável preço relativo tem seu sinal esperado, mas não é significativamente diferente de zero, e seu valor indica que a demanda de exportação de painéis à base de madeira é inelástica com relação à variações de preço. A elasticidade-preço de curto prazo é $-0,148$, e a elasticidade de longo prazo é $-0,592$.

O coeficiente estimado para a variável renda externa indica que a demanda de exportação de painéis à base de madeira também é inelástica em relação a variações na renda mundial. A elasticidade-renda de curto-prazo é 0,387 .

Restam, finalmente, algumas considerações a cerca das estimativas do coeficiente da variável câmbio nas equações de oferta de exportação de madeira serrada

\footnotetext{
${ }^{43}$ Além disso, a elasticidade de $U_{t}$ sugere uma elevada flexibilidade entre o mercado doméstico e o mercado externo. Portugal (1993) e Zagury (1994), que estimaram equações de exportação para os manufaturados, se depararam com níveis de elasticidade para aquela variável ainda mais elevados.
} 
de não coníferas (Tabela 11) e de painéis à base de madeira (Tabela 13). Embora significativas, essas estimativas não apresentaram o sinal esperado.

Primeiramente o efeito de uma desvalorização (valorização) cambial sobre as exportações pode ocorrer com um certo retardamento. Os indícios são, segundo Williamson (1989), que as respostas do comércio internacional (em volume transacionado) às variações de preço induzidas pelas desvalorizações da moeda são nitidamente demoradas. Assim,

"(...) o ajuste praticamente completo pode levar três ou quatro anos. Isso talvez se deva ao fato de se fazer muito comércio com um fornecedor costumeiro e de que mudar a fonte de fornecimento é algo que só se faz após muito estudo e quando os beneficios prometem durar o bastante para fazer com que a troca valha a pena" (Williamson, 1989, p.145).

Segundo Zini (1993, p.138), "o coeficiente de curto prazo para as mudanças cambiais é ambíguo (dada a defasagem de resposta). Já o coeficiente defasado da taxa de câmbio, com elasticidades "normais", deve ser positivo".

Assim, foram estimadas regressões para as exportações de madeira serrada de não coniferas e de painéis à base de madeira considerando-se defasagens de até cinco anos para a variável taxa de câmbio ${ }^{44}$. Isso, porém, não melhorou os resultados (ver Apêndice 3).

Talvez o conceito utilizado de taxa de câmbio (taxa de câmbio efetiva) pode não ser o melhor conceito para produtos específicos (dado o esquema de ponderação usado), como é o caso da madeira serrada de não coníferas e dos painéis à

\footnotetext{
${ }^{44}$ Juns \& Roh, citados por Almeida (1998), apontam, ainda, outras razões para a existência da defasagem às variações na taxa de câmbio, que consideradas em conjunto podem levar até cinco anos. São elas: o retardamento que compreende a variação na taxa de câmbio corrente e o reconhecimento, por parte dos agentes econômicos, de que o preço, induzido por uma variação cambial, realmente mudou; e, o retardamento econômico, que envolve a decisão de mudar variáveis reais, a recomposição dos estoques, a alteração na produção e tempo de entrega.
} 
base de madeira. Regressões para esses produtos usando o conceito da taxa de câmbio bilateral ${ }^{45}$ foram testadas. Isso, igualmente, não melhorou os resultados (Apêndice 3).

Reis \& Crespo (1998) também obtiveram elasticidade-câmbio negativa para as exportações brasileiras de açúcar. Segundo esses autores, análises da evolução da taxa de câmbio real em relação às cotações internacionais do açúcar indicaram que ela foi valorizada em anos de melhores cotações internacionais e desvalorizada em anos de queda do preço internacional. Como os anos de melhores cotações coincidiram com um maior volume exportado, os autores concluem que, em anos de preços elevados, este estímulo foi superior a uma taxa de câmbio valorizada (acontecendo o contrário em anos de baixas cotações internacionais). Cavalcanti \& Ribeiro (1998) observaram fenômeno semelhante para as exportações brasileiras no período de 1977 a $1996^{46}$. Isso pode ter ocorrido com alguns dos produtos aqui considerados (principalmente aqueles de maior peso na pauta de exportações de produtos sólidos de madeira), o que justificaria o sinal negativo encontrado para o coeficiente associado à variável câmbio.

\footnotetext{
${ }^{45} \mathrm{O}$ índice de taxa de câmbio real bilateral, aqui utilizado, deflaciona a taxa de câmbio real/dólar média anual pelo relativo de preços entre o índice de preços por atacado no Brasil e o índice de preços por atacado nos Estados Unidos. As séries utilizadas são do IPEA.

${ }^{46}$ Cabe observar que esses autores incorporam o efeito-preço e o efeito-câmbio em uma única variável (o conceito rentabilidade real das exportações discutido no capítulo 3), não implicando troca de sinal do coeficiente estimado.
} 


\section{CONCLUSÃO}

Este trabalho analisou o comportamento das exportações brasileiras de madeira serrada e painéis à base de madeira no período de 1961 a 1999. Para tanto, a evolução das indústrias de madeira serrada e de painéis à base de madeira e a inserção do Brasil no mercado internacional desses produtos foram analisadas. A seguir, foram definidas equações estruturais de oferta e demanda para as exportações dos seguintes produtos: madeira serrada de coníferas, madeira serrada de não coníferas e painéis à base de madeira.

Até a década de 60 , a produção de madeira serrada estava concentrada na região sul do País. Isto se justificava pela ocorrência nesta região das reservas de Araucária angustifólia. Pari passu ao esgotamento dessas reservas, a região norte assumiu a hegemonia na produção de madeira serrada de espécies tropicais. Assim, a disponibilidade de matéria-prima foi o fator determinante da distribuição geográfica da indústria de madeira serrada ao longo do período analisado.

A ausència de significativas barreiras à entrada na indústria de madeira serrada incitou o aumento do número de serrarias nas regiões já referidas. Em 1999, existiam no Brasil 9630 unidades produtoras de serrados, predominando as de pequeno porte (apenas $0,7 \%$ apresentavam capacidade de produção média e grande).

A pequena capacidade de investimento dessas unidades industrias implica condições precárias de produção, baixo nível de produtividade, reduzido grau de automação e de modernização e má qualidade dos produtos. 
A partir da década de 90 , a madeira de pinus proveniente de reflorestamento passou a ser uma importante fonte de matéria-prima para a indústria de madeira serrada. O eucalipto vem se mostrando, também, uma espécie de grande potencial. Aliás, a produção de madeira serrada de eucalipto por parte de empresas produtoras de celulose viabilizaria investimentos em serrarias intensivas em capital. É indicativo, nesse sentido, a implantação pela Aracruz Celulose de uma serraria com capacidade produtiva de $75 \mathrm{mil} \mathrm{m}^{3} / \mathrm{ano}$.

Outro fenômeno observado em anos recentes, além da utilização de espécies oriundas de reflorestamento, foi a produção de produtos serrados de maior valor agregado. A elaboração desses produtos é menos seletiva com relação às espécies utilizadas, ajusta-se ao uso de árvores de dimensões menores e gera menos resíduos em sua produção. Isso tem um forte apelo ecológico.

Em 1999, a produção brasileira de madeira serrada atingiu 18,6 milhões de $\mathrm{m}^{3}$ e cresceu, em média, 3,9\% ao ano no período de 1961 a 1999, contra apenas $0,5 \%$ da média mundial. Não obstante, o Brasil ainda detém pequena participação na produção mundial de madeira serrada, 4,3\% em 1999. A participação do Brasil no mercado internacional de madeira serrada, por sua vez, é ainda mais modesta. Em 1999, o Brasil foi responsável por apenas 1,6\% das exportações mundiais de madeira serrada.

As alterações na participação do Brasil no mercado internacional de madeira serrada se deu na razão direta da evolução desta indústria. Assim, até a década de 70 a Araucária angustifólia foi a principal espécie na pauta de exportação de madeira serrada. Com a exaustão das reservas nativas no sul do País, as madeiras serradas de espécies tropicais ganharam espaço na pauta de exportação. Pôde-se inferir, das baixas taxas de crescimento das exportações de madeira serrada nesse periodo de transição, o quão cauteloso é o mercado internacional em relação ao consumo de novas espécies.

A questão ambiental foi, sem dúvida, um fator limitativo a maior participação do Brasil no mercado internacional de madeira serrada (e de outros 
produtos de madeira). Os embargos e restrições ao livre comércio afetou mais as espécies tropicais do que as temperadas. Isso incitou o crescimento das exportações de pinus a partir da década de 90 .

A estrutura produtiva de painéis à base de madeira é bastante heterogênea, coexistindo unidades com diferentes niveis tecnológicos. A maior parte das unidades produtoras de compensado e aglomerado opera com baixo nível de produtividade e encontra-se desatualizada tecnologicamente. As empresas produtoras de chapas de fibras apresentam elevado nível de produtividade e qualidade e alto grau de modernidade industrial e automação.

A participação do Brasil na produção mundial de painéis de madeira é bastante modesta. Considerando o total de painéis produzidos em 1999, a participação brasileira não atinge $2 \%$. O produto com que o Brasil tem maior participação é a chapa de fibra dura, com cerca de $7,6 \%$ da produção mundial, seguido pelo compensado de madeira tropical, com uma participação de aproximadamente $7 \%$.

No periodo de 1961 a 1999, as exportações brasileiras de painéis a base de madeira cresceram, em média, 11,9\% ao ano. Não obstante, em 1999 o Brasil contribuiu com apenas $2,5 \%$ das exportações mundiais de painéis à base de madeira.

O maior entrave à maior participação do Brasil no mercado internacional de painéis de madeira, durante o periodo analisado, deu-se do lado da demanda. Nesse caso, também, as restrições ambientais tiveram papel decisivo. $O$ compensado e a chapa de fibra dura foram os produtos mais afetados. Isso se deveu à redução do "tamanho do mercado" destes painéis em nível mundial.

O Brasil tem grandes perspectivas de se tornar um grande produtor e exportador de painéis de madeira. O crescimento será maior para os painéis do tipo reconstituído, o que se deve, em princípio, aos expressivos investimentos em unidades de produção de chapas de aglomerado e MDF que foram realizadas em anos recentes. 
O compensado produzido a partir de madeira de árvores do tipo folhosas representa outra grande oportunidade de produção para os países com disponibilidade de matéria-prima em quantidade e qualidade adequadas. A Indonésia e a Malásia são, atualmente, os maiores produtores de compensado tropical, porém, eles vêm reduzindo os estoques de madeira disponíveis para esse uso e, como resultado, tiveram sua produção reduzida em 1999 em cerca de $27 \%$ e 12\%, respectivamente, em relação à produção de 1998 .

Além das madeiras de árvores nativas tropicais, os desenvolvimentos recentes com o emprego do eucalipto oriundo de florestas plantadas em usos não tradicionais têm mostrado boas perspectivas como alternativa às madeiras tropicais na produção de compensado e outros painéis destinados à produção de elementos estruturais, a exemplo do LVL. O compensado de pinus, produto em franca ascensão da produção, também reúne características que podem torná-lo altamente competitivo no mercado internacional.

A partir da análise da evolução da indústria e das exportações de madeira serrada e de painéis de madeira, foram especificadas as equações de oferta e demanda de exportação para estes produtos. Os modelos de ajustamento do balanço de pagamentos e os trabalhos empíricos que tratam das exportações de manufaturados foram utilizados para auxiliar no processo de seleção das variáveis a serem incluídas nas equações.

As exportações brasileiras de madeira serrada de coníferas foram estimadas em dois períodos, quais sejam, 1961/87 e 1988/99. A quebra de tendência dessas exportações em 1987 foi testada estatisticamente por meio do ajustamento de uma poligonal. Não obstante, as estimativas obtidas para os dois subperíodos não foram satisfatórias.

A inserção do Brasil no mercado internacional de madeira serrada de coníferas esteve inicialmente ligada às reservas de pinheirais do Paraná e a abertura de novas frentes agrícolas. $\mathrm{O}$ caráter extrativista e predatório dessa atividade fez a indústria 
de madeira serrada de coníferas ser uma atividade com características próprias. A disponibilidade de matéria-prima foi, sem dúvida, o principal determinante das exportações de madeira serrada de coníferas no período analisado.

As estimativas das equações de oferta e demanda de madeira serrada de não coníferas foram bastante satisfatórias. Dos resultados obtidos infere-se que a oferta de exportação de madeira serrada de não coníferas é elástica com relação ao preço. A dificuldade de introdução de novas espécies no mercado externo (dada a preferência dos consumidores pelas espécies coniferas) e as inúmeras restrições ambientais por parte dos países consumidores refletiram-se em baixa elasticidade-renda na equação de demanda e em um coeficiente negativo para a variável produção na equação de oferta.

Os resultados encontrados no modelo estimado para os painéis à base de madeira sugerem que as especificações das equações de oferta e demanda constituem uma representação bastante razoável para as exportações brasileiras de painéis de madeira. Pôde-se constatar que a oferta brasileira de exportação de painéis à base de madeira é sensivel à variação de preço. A oferta de exportação também mostra uma resposta negativa significativa em relação à variável cíclica. Isto reflete, por um lado, a flexibilidade entre os mercados interno e externo e, por outro, o fato de que a atividade exportadora é apenas uma alternativa para períodos de baixa demanda interna (exceto para o caso de harboard). Este fato, a longo prazo, pode ser um fator limitativo para o crescimento sustentado das exportações brasileiras de painéis de madeira.

A baixa elasticidade-renda da demanda de exportação de painéis de madeira indica a dificuldade de o Brasil penetrar em novos mercados. Isso sugere que as restrições por parte dos países consumidores podem representar também um fator limitativo à maior inserção do Brasil no mercado internacional deste produto.

Assim, a análise do comportamento das exportações brasileiras de madeira serrada e painéis à base de madeira durante o período de 1961 a 1999 sugere que tanto fatores de oferta quanto fatores de demanda foram importantes para sua 
determinação. Apesar de influenciarem decisivamente a quantidade ofertada, o nivel de preços, os ciclos de demanda interna e a capacidade produtiva destas indústrias não são suficientes (apesar de serem necessárias) para explicar o desempenho dessas exportações. Restrições de demanda externa, resultantes de redução do nível de atividade internacional, práticas protecionistas ou alterações de preços relativos, por exemplo, podem atuar como limitantes à expansão das exportações.

A hipótese do "país pequeno" no mercado internacional e que, portanto, enfrenta uma curva de demanda externa infinitamente elástica não parece plausível para o caso das exportações de produtos sólidos de madeira. Isso vem reforçar a idéia de que um modelo simultâneo é a especificação adequada para analisar as exportações brasileiras de madeira serrada e painéis à base de madeira.

Vale ressaltar as necessidades de posteriores refinamentos no modelo desenvolvido. A econometria tradicional, baseada no modelo de regressão clássico e nos estimadores de mínimos quadrados, tem sofrido críticas quanto a sua adequação para considerar variáveis econômicas. Isto, contudo, não invalida os resultados básicos obtidos. Os procedimentos aqui empregados têm sido amplamente utilizados na literatura, os quais têm gerado resultados bastante satisfatórios. Outros estudos poderão ser desenvolvidos, com análise mais pormenorizadas a nível de principais produtos. Haveria possibilidade de melhor avaliar questões relacionadas à competitividade, barreiras comerciais, diferenciação dos produtos etc.

Resta, finalmente, observar as perspectivas do Brasil em aumentar sua participação no mercado internacional de produtos sólidos de madeira. A constatação imediata é de que as exportações de produtos sólidos de madeira apresentam grande vulnerabilidade, especialmente os produtos mais representativos, a saber, madeira serrada e compensado, visto estarem apoiados em larga escala em recursos florestais nativos e, assim, sujeitos a eventuais retaliações internacionais.

Sobre esse aspecto, vale lembrar que nos paises desenvolvidos as restrições no suprimento de madeira levarão ao crescimento da produção de produtos 
reconstituídos. Assim, a oportunidade de ampliar mercados para produtos como o compensado ficaria para países que possuem recursos florestais em quantidade e qualidade adequadas.

Ampliar significativamente as exportações brasileiras de produtos sólidos de madeira a partir da estrutura produtiva existente é inviável sob o ponto de vista ambiental. Não obstante, o Brasil tem condições de formar extensas áreas plantadas com espécies de rápido crescimento, que viabilizariam uma expansão considerável da produção de painéis à base de madeira.

A madeira serrada de eucalipto, ainda pouco utilizada no País, teria condições de produção bastante competitivas no mercado externo. A integração entre as indústrias de celulose e de madeira serrada permitiria explorar as sinergias potencialmente existentes entre estas indústrias. Isto permitiria o país produzir produtos sólidos de madeira com maior conteúdo tecnológico e com maior diferenciação quanto às espécies florestais utilizadas. Além disso, o apelo ecológico das florestas de rápido crescimento é um forte elemento de marketing dos produtos a serem obtidos da exploração dessas florestas. 


\section{REFERÊNCIAS BIBLIOGRÁFICAS}

ADAMS, M.; JOHNSON, S. Nuvens sombrias que vêm da Ásia. Revista da Madeira, v.6, n.38, p.24-28, 1998.

ALMEIDA, C.O. Política cambial e receita de exportações de café no Brasil - 1970/89. Fortaleza, 1993. 66p. Dissertação (M.S.) - Universidade Federal do Ceará.

ALMEIDA, C.O. Taxa de câmbio e determinantes da balança comercial de produtos agrícolas e agroindustriais do Brasil: 1961 a 1995. Piracicaba, 1998. 105p. Tese (Doutorado) - Escola Superior de Agricultura "Luiz de Queiroz", Universidade de São Paulo.

ALMEIDA, C.O.; MESQUITA, T.C. Causalidade entre preços externos e quantidades exportadas de café no mercado internacional - 1965/89. Pesquisa e Planejamento Econômico, v.25, n.3, p.527-540, dez.1995.

AMAZONAS, A.; BARROS, A.R. Manufactured exports from Brazil: determinants and consequences. Revista Brasileira de Economia, v.50, n.1, p.73-100, jan./mar. 1995.

ANGELO, H. As exportações brasileiras de madeiras tropicais. Curitiba, 1998. 129p. Tese (Doutorado) - Universidade Federal do Paraná.

ANGELO, H.; SILVA, D.A. As exportações brasileiras de mogno (Swietenia macrophylla, King). Revista Árvore, v.22, n.1, p.113-121, 1998.

ASSOCIAÇÃO BRASILEIRA DA INDÚSTRIA DA MADEIRA PROCESSADA MECANICAMENTE. A indústria de produtos de madeira sólida no Brasil: 1999. http://www.abimci.com.br/index_port.htm (12/12/2000). 
AZEREDO, N.R.S. de. O Brasil e o mercado mundial de produtos de madeira. In: ENCONTRO BRASILEIRO DE ECONOMIA FLORESTAL, 1., Curitiba, 1988. Anais. Curitiba: EMBRAPA/CNPF, 1988. v.1, p.391-418.

BANCO NACIONAL DE DESENVOLVIMENTO ECONÔMICO E SOCIAL. Produtos florestais: madeira em tora, madeira serrada e painéis - panorama 1980/1992. Relatos Setoriais, 1995. http://www.bndes.gov.br/publical/relato/ rel4cor.exe $(25 / 10 / 2000)$.

BONELLI, R.; MALAN, P.S. Os limites do possível: notas sobre balanço de pagamentos e indústria no anos 70. Pesquisa e Planejamento Econômico, v.6, n.2, p.353-406, ago. 1976.

BRAGA, H.C.; MARKWALD, R.A. Funções de oferta e de demanda das exportações de manufaturadas no Brasil: estimação de um modelo simultâneo. Pesquisa e Planejamento Econômico, v.13, n.3, p.707-744, dez. 1983.

BRANSON, W.H.; LITVACK, J.M. Macroeconomia. 2.ed. São Paulo: Harper e Row, 1979. 793p.

BRITO, E.O. Estimativa da produção de resíduos na indústria brasileira de serraria e laminação. Revista da Madeira, v.4, n.26, p.34-39, 1996.

CARDOSO, E.; DORNBUSCH, R. Uma equação para as exportações brasileiras de produtos manufaturados. Revista Brasileira de Economia, v.34, n.3, p.429-437, jul./set.1980.

CARVALHO, J.L.; HADDAD, C.L.S. A promoção de exportações: a experiência brasileira até 1974. Revista Brasileira de Economia, v.32, n.1, p.105-135, jan./mar.1978. 
CASTRO, A.S. de; CAVALCANTI, M.A.F.H. Estimação de equações de exportação e importação para o Brasil - 1955/95. Pesquisa e Planejamento Econômico, v.28, n.1, p.1-68, abr.1998.

CAVALCANTI, M.A.F.H.; RIBEIRO, F.J. As exportações brasileiras no período 1977/96: desempenho e determinantes. Rio de Janeiro: IPEA, fev.1998. 46p. (Texto para Discussão, 545)

CONJUNTURA ECONÒMICA. Indicadores Industriais. Rio de Janeiro: Fundação Getúlio Vargas, v. 54, n.1 e 7, 2000.

DIVERSIFICAÇÃO garante exportação de madeira. Revista da Madeira, v.5, n.27, p.18-19, 1996.

DOLLINGER, C. von. et al. Transformação da estrutura das exportações brasileiras: 1964/70. Rio de Janeiro: IPEA/INPES, 1973. (Relatório de Pesquisa, 14)

FLÂNDOLI SOBRINHO, V. A importância do Brasil no mercado internacional de madeira e derivados. In: SIMPÓSIO BRASILEIRO SOBRE COLHEITA E TRANSPORTE FlORESTAL, 2., Salvador, 1995. Anais. Viçosa: SIF, 1995. p.52-63.

FOOD AND AGRICULTURE ORGANIZATION OF THE UNITED NATIONS. FAO Statistical Database. http://www.fao.org (12/02/2001).

GARIPP, R.C.; OLIVEIRA, A.S. Incentivos fiscais: o Brasil parando no tempo. Silvicultura, v.18, n. 72, p.24-28, jul./ago.1997.

GOLDSTEIN, M.; KHAN, M.S. The supply and demand for exports: a simultaneous approach. The Review of Economics and Statistics, v.60, n.2, p.257-286, May 1978.

GRESHAM, G. Consumo em alta. Oferta em Baixa. Revista da Madeira, v.4, n.25, p. 10-13, 1995. 
GUJARATI, D.N. Basic Econometrics. 3.ed. New York: McGraw-Hill, 1995, 838 p.

HILGEMBERG, E.M. Impactos das pressões ambientais sobre a conduta e o desempenho da indústria brasileira de celulose. Piracicaba, 2000. 156p. Dissertação (M.S.) - Escola Superior de Agricultura "Luiz de Queiroz", Universidade de São Paulo.

HOFFMANN, R.; VIEIRA, S. Análise de regressão: uma introdução à econometria. 3.ed. São Paulo: HUCITEC, 1987. 379 p.

HOUTHAKKER, H.S.; MAGEE, S.P. Income and price elasticities in world trade. The Review of Economics and Statistics, v.51, n.2, p.111-125, May 1969.

INSTITUTO DE PESQUISA ECONÔMICA APLICADA. IPEADATA. http://www.ipeadata.gov.br (20/03/2001).

INTERNATIONAL MONETARY FUND. International Financial Statistics (compact disc). Washington: IMF. Publications Service, 1999-2000.

ISO 14000: a excelência total em meio ambiente. Revista da Madeira, v.5, n.27, p.5-8, 1996.

LADEIRA, H.P. Considerações sobre os fatores que influenciam na exportação dos produtos florestais no Brasil. In: ENCONTRO BRASILEIRO DE ECONOMIA FLORESTAL, 1., Curitiba, 1988. Anais. Curitiba: EMBRAPA/CNPF, 1988. v.1, p.267-287.

LEMGRUBER, A.C. O balanço de pagamentos do Brasil - uma análise quantitativa. Pesquisa e Planejamento Econômico, v.6, n.2, p.313-352, ago. 1976.

LOPES, F.L.; RESENDE, A.L. A inflação e o balanço de pagamentos: uma análise quantitativa das opções de política econômica. Rio de Janeiro: PUC, 1981. (Relatório de Pesquisa, 1) 
MACEDO, A.R.P.; ROQUE, C.A.L. Painéis de Madeira. BNDES Setorial, n.6, p.117-132, set.1997.

MACEDO, A.R.P.; ROQUE, C.A.L.; LEITE, E.T. Produtos Sólidos de Madeira. BNDES Setorial, p.157-176, out.1997. Edição especial.

MERCADO, R.S.; CAMPAGNANI, S. Exportações da floresta amazônica. In: ENCONTRO BRASILEIRO DE ECONOMIA FLORESTAL, 1., Curitiba, 1988. Anais. Curitiba: EMBRAPA/CNPF, 1988. v.1, p.43-73.

MUSALEM, A.R. Política de subsídios e exportações de manufaturados no Brasil. Revista Brasileira de Economia, v.35, n.1, p.17-41, jan./mar.1981.

NAHUZ, M.A.R. Certificação ambiental de produtos. O papel, v.56, n.4, p.15-22, abr. 1995.

NAHUZ, M.A.R.; WATAI, L.T. Uma visão ampla dos materiais à base de madeira no Brasil. Silvicultura, v.19, n.75, p.34-38, mai./ago.1998.

NEVES, R.B. A utilização da capacidade produtiva na indústria brasileira - 1975/75. Pesquisa e Planejamento Econômico, v.8, n.2, p.299-330, ago.1978.

OLIVEIRA, E.T. Análise setorial das exportações brasileiras de lâminas, compensados, chapas de fibra e madeira aglomerada. In: ENCONTRO BRASILEIRO DE ECONOMIA FLORESTAL, 1., Curitiba, 1988. Anais. Curitiba: EMBRAPA/ CNPF, 1988. v.1, p.213-234.

PARENTE, W.C. Estrutura do comércio internacional de amêndoas de caju (ACC) do Brasil. Fortaleza, 1990. 149 p. Dissertação (M.S.) - Universidade Federal do Ceará.

PESSOA, P.F.A.P.; LEMOS, J.J.S. Mercado de exportação e estabilização de preços externos para amêndoas de castanha de caju. Revista de Economia e Sociologia Rural, v.30, n.2, p.171-187, abr./jun.1992. 
PINTO, M.B.P. O crescimento das exportações brasileiras de manufaturados: 1954-1974. Estudos Econômicos, v.10, n.3, p.101-143, 1980.

- Política cambial, política salarial e o potencial das exportações de manufaturados do Brasil no período 1954-74. Revista de Econometria, v.3, n.2, p. 87-104, nov. 1983.

PORTUGAL, M.S. A instabilidade dos parâmetros nas equações de exportação brasileiras. Pesquisa e Planejamento Econômico, v.23, n.2, p.313-348, ago. 1993.

REIS, J.N.P.; CRESPO, J.E.Q. Um modelo econométrico para as exportações de açucar do Brasil. Agricultura em São Paulo, v.45, n.1, p.17-32, 1998.

RIBEIRO, H.; MACHADO, L.M.G. Contribuição do setor florestal ao comércio exterior brasileiro. Brasil Florestal, v.12, n.49, p.7-22, jan./mar.1982.

RIOS, S.M.C.P. Exportações brasileiras de produtos manufaturados: uma avaliação econométrica para o periodo 1964/84. Pesquisa e Planejamento Econômico, v.17, n.2, p.299-332, ago.1987.

ROQUE, C.A.L.; VALENÇA, A.C.V. Painéis de madeira aglomerada. BNDES Setorial, n.8, p.153-170, set.1998.

SANTOS, F.L.C. dos. Perspectivas do mercado nacional de madeiras serradas oriundas de florestas plantadas. In: SIMPÓSIO IPEF, 6., Águas de São Pedro, 1996. A reengenharia e seus impactos no desenvolvimento científico e tecnológico do setor florestal. Anais. Piracicaba: IPEF, 1996. v.6, p.31-52.

SILVA, R.; BRAVO, M.A.M. Comércio exterior e meio ambiente. Revista do BNDES, v.1, n.1, p.113-128, jun.1994.

SPERANDIO, J.P.; KEINERT JÚNIOR, S. Análise da demanda e oferta de compensado do estado do Paraná. Revista Floresta, v.19, n. 1/2, p.82-85, 1989. 
TOMASELLI, I. A indústria de painéis no Brasil e no mundo: tendências de mudanças do perfil de produção e usos. In: SEMINÁRIO INTERNACIONAL SOBRE PRODUTOS SÓLIDOS DE MADEIRA DE ALTA TECNOLOGIA, 1.; ENCONTRO SOBRE TECNOLOGIAS APROPRIADAS DE DESDOBRO, SECAGEM E UTILIZAÇÃO DA MADEIRA DE EUCALIPTO, 1., Belo Horizonte, 1998. Anais. Belo Horizonte: SIF/UFV, 1998. p.55-64.

TYLER, W.G. O viés antiexportação em políticas comerciais e o desempenho das exportações: alguns aspectos da recente experiência brasileira. Revista Brasileira de Economia, v.36, n.2, p.183-196, abr./jun. 1982.

VALENÇA, C.A.V; ROQUE, C.A.; SOUZA, P.Z. Painéis de madeira aglomerada. Informes Setoriais, 1999. http://www.bndes.gov.br/Setorial/is_g1_20.exe $(25 / 10 / 2000)$.

VALENÇA, C.A.V; ROQUE, C.A.; SOUZA, P.Z. MDF - Medium Density Fiberboard Informes Setoriais, 2000. http:// www.bndes.gov.br/publica/Setorial/is_g1_20.exe $(25 / 10 / 2000)$

VALVERDE, S.R.; TEIXEIRA, E.C.; SILVA, M.L. da. Impactos da liberalização do comércio internacional nos produtos florestais da economia brasileira. Revista Árvore, v.21, n.2, p.243-251, 1997.

VERÍSSIMO, A. et al. Logging impacts and prospects for sustainable forest management in na old Amazonian frontier: the case of Paragominas. Forest Ecology and Management, v.55, n.1/4, p.169-199, dez.1992.

ZAGURY, S. Um modelo para o balanço de pagamentos: estimativas econométricas e projeções. Rio de Janeiro, 1994. 143p. Dissertação (M.S.) - Pontificia Universidade Católica do Rio de Janeiro. 
ZANIOLO, A. Análise setorial das exportações brasileiras da indústria madeireira. In: ENCONTRO BRASILEIRO DE ECONOMIA FLORESTAL, 1., Curitiba, 1988. Anais. Curitiba: EMBRAPA/CNPF, 1988. v.1, p.171-194.

ZINI JÚNIOR, A.A. Funções de exportação e de importação para o Brasil. Pesquisa e Planejamento Econômico, v.18, n.3, p.615-662, dez.1988.

Taxa de câmbio e política cambial no Brasil. São Paulo: EDUSP/BM\&F, 1993. 192p.

ZUGMAN, I. C. Painel geral sobre a produção de compensados. Silvicultura, v.15, n. 55, p. $12-18$, mai./jun. 1994.

Estrutura das indústrias e comércio de madeira compensada e laminada no Brasil e no mundo. In: SEMINÁRIO INTERNACIONAL SOBRE PRODUTOS SÓlIDOS DE MADEIRA DE ALTA TECNOLOGIA, 1; ENCONTRO SOBRE TECNOLOGIAS APROPRIADAS DE DESDOBRO, SECAGEM E UTILIZAÇÃO DA MADEIRA DE EUCALIPTO, 1,, Belo Horizonte, 1998. Anais. Belo Horizonte: SIF/UFV, 1998. p.49-54.

WILLIAMSON, J. A economia aberta e a economia mundial: um texto de economia internacional. Rio de Janeiro: Campus, 1989. 412p. 


\section{APÊNDICE 1}

Dados básicos utilizados na estimação das equações de oferta e demanda de exportação de madeira serrada e de painéis à base de madeira 
Tabela 1.1 Dados básicos utilizados nas estimativas das equações de oferta e demanda de exportação de madeira serrada de coníferas

\begin{tabular}{|c|c|c|c|c|c|c|c|}
\hline Ano & $Q_{t}$ & $P X_{t}$ & $P W_{t}$ & $E_{t}$ & $U_{t}$ & $Y_{t}$ & $Y W_{t}$ \\
\hline 1961 & 1095 & 122 & 106 & 65 & 93 & 3275 & 36474 \\
\hline 1962 & 825 & 129 & 102 & 73 & 91 & 3503 & 38225 \\
\hline 1963 & 800 & 128 & 102 & 64 & 84 & 2821 & 40683 \\
\hline 1964 & 1055 & 128 & 106 & 78 & 81 & 2801 & 43759 \\
\hline 1965 & 1126 & 128 & 108 & 89 & 79 & 2961 & 43323 \\
\hline 1966 & 1198 & 127 & 105 & 76 & 80 & 3273 & 41614 \\
\hline 1967 & 1034 & 132 & 102 & 69 & 81 & 3618 & 42567 \\
\hline 1968 & 1312 & 142 & 103 & 71 & 86 & 3865 & 47099 \\
\hline 1969 & 1023 & 185 & 110 & 74 & 89 & 4167 & 47346 \\
\hline 1970 & 927 & 183 & 108 & 74 & 91 & 4535 & 49250 \\
\hline 1971 & 994 & 176 & 111 & 75 & 94 & 4500 & 51265 \\
\hline 1972 & 836 & 188 & 121 & 77 & 97 & 4350 & 57138 \\
\hline 1973 & 688 & 284 & 149 & 81 & 100 & 3665 & 61166 \\
\hline 1974 & 384 & 384 & 162 & 80 & 97 & 3665 & 52566 \\
\hline 1975 & 310 & 326 & 137 & 84 & 92 & 5469 & 43045 \\
\hline 1976 & 177 & 307 & 137 & 81 & 93 & 5846 & 54716 \\
\hline 1977 & 192 & 270 & 139 & 81 & 88 & 6590 & 61172 \\
\hline 1978 & 178 & 332 & 139 & 85 & 86 & 6952 & 65747 \\
\hline 1979 & 234 & 335 & 150 & 94 & 86 & 7334 & 67899 \\
\hline 1980 & 187 & 365 & 138 & 100 & 89 & 7143 & 64499 \\
\hline 1981 & 157 & 314 & 116 & 85 & 79 & 7475 & 58813 \\
\hline 1982 & 126 & 272 & 103 & 79 & 76 & 7766 & 59924 \\
\hline 1983 & 114 & 387 & 101 & 94 & 72 & 8110 & 68071 \\
\hline 1984 & 80 & 285 & 95 & 86 & 74 & 8384 & 70730 \\
\hline 1985 & 72 & 234 & 92 & 85 & 78 & 8384 & 73014 \\
\hline 1986 & 81 & 251 & 105 & 86 & 83 & 8384 & 73751 \\
\hline 1987 & 67 & 632 & 112 & 88 & 83 & 8384 & 75895 \\
\hline 1988 & 119 & 233 & 118 & 78 & 80 & 8384 & 77632 \\
\hline 1989 & 114 & 177 & 123 & 62 & 79 & 8384 & 78397 \\
\hline 1990 & 80 & 148 & 133 & 58 & 72 & 7923 & 75435 \\
\hline 1991 & 120 & 221 & 127 & 69 & 71 & 8591 & 70449 \\
\hline 1992 & 250 & 179 & 128 & 71 & 70 & 8591 & 75147 \\
\hline 1993 & 350 & 150 & 134 & 64 & 73 & 8591 & 80999 \\
\hline 1994 & 494 & 175 & 142 & 54 & 77 & 8591 & 89689 \\
\hline 1995 & 496 & 194 & 137 & 46 & 80 & 8591 & 88249 \\
\hline 1996 & 410 & 183 & 137 & 48 & 80 & 8591 & 90826 \\
\hline 1997 & 548 & 187 & 139 & 45 & 80 & 8591 & 96646 \\
\hline 1998 & 677 & 171 & 124 & 51 & 78 & 8591 & 99241 \\
\hline 1999 & 1015 & 158 & 126 & 60 & 77 & 8591 & 105141 \\
\hline
\end{tabular}

Fonte: As séries referentes à quantidade exportada de madeira serrada de coníferas $\left(Q_{t}\right)$, quantidade produzida de madeira serrada de coníferas $\left(Y_{f}\right)$; quantidade mundial exportada de madeira serrada de coníferas $\left(Y W_{t}\right)$ são da FAO. Esses valores estão expressos em mil $\mathrm{m}^{3}$. Os preģos das exportaçóes brasileiras de madeira serrada de coniferas $(P X)$, e das exportaçōes mundiais de madeira serrada de coníferas $\left(P W_{t}\right)$, expressos em dólares reais, são medidos pelo valor unitários dessas exportaçỏes. Os dados utilizados para esses cálculos também são da FAO. O IPA dos Estados Unidos, utilizado para transformar em valores reais as séries de preço é do FMI, disponivel em International Financial Statistics. A série de taxa de câmbio efetiva real $\left(E_{\eta}\right)$ foi construída a partir de duas fontes distintas: Almeida (1998) e IPEA. A taxa de utilização da capacidade $\left(U_{t}\right)$ é a calculada em Castro \& Cavalcanti (1998) e atualizada pela série da FGV, disponivel em Conjuntura Econômica. 
Tabela 1.2 Dados básicos utilizados nas estimativas das equações de oferta e demanda de exportação de madeira serrada de não coníferas

\begin{tabular}{llllllll}
\hline Ano & $\boldsymbol{Q}_{\boldsymbol{t}}$ & $\boldsymbol{P} \boldsymbol{X}_{\boldsymbol{t}}$ & $\boldsymbol{P W}$ & $\boldsymbol{E}_{\boldsymbol{t}}$ & $\boldsymbol{U}_{\boldsymbol{t}}$ & $\boldsymbol{Y}_{\boldsymbol{t}}$ & $\boldsymbol{Y} \boldsymbol{W}_{\boldsymbol{t}}$ \\
\hline 1970 & 147 & 159 & 156 & 74 & 91 & 3500 & 7124 \\
\hline 1971 & 161 & 152 & 151 & 75 & 94 & 3600 & 7164 \\
\hline 1972 & 204 & 151 & 178 & 77 & 97 & 3200 & 8167 \\
\hline 1973 & 367 & 165 & 207 & 81 & 100 & 3444 & 10928 \\
\hline 1974 & 328 & 202 & 220 & 80 & 97 & 3977 & 10052 \\
\hline 1975 & 190 & 197 & 193 & 84 & 92 & 4659 & 8631 \\
\hline 1976 & 262 & 188 & 195 & 81 & 93 & 5397 & 10812 \\
\hline 1977 & 405 & 287 & 208 & $\mathbf{8 1}$ & 88 & 6053 & 11645 \\
\hline 1978 & 391 & 192 & 209 & 85 & 86 & 6385 & 12118 \\
\hline 1979 & 593 & 268 & 241 & 94 & 86 & 6736 & 13767 \\
\hline 1980 & 622 & 230 & 241 & 100 & 89 & 7738 & 13246 \\
\hline 1981 & 579 & 248 & 199 & 85 & 79 & 8377 & 11846 \\
\hline 1982 & 397 & 230 & 186 & 79 & 76 & 8704 & 11301 \\
\hline 1983 & 459 & 250 & 187 & 94 & 72 & 9089 & 12301 \\
\hline 1984 & 446 & 227 & 171 & 86 & 74 & 9397 & 12572 \\
\hline 1985 & 421 & 212 & 169 & 85 & 78 & 9397 & 12692 \\
\hline 1986 & 375 & 233 & 200 & 86 & 83 & 9679 & 12850 \\
\hline 1987 & 486 & 291 & 204 & 88 & 83 & 9679 & 15729 \\
\hline 1988 & 533 & 267 & 201 & 78 & 80 & 9795 & 16142 \\
\hline 1989 & 448 & 219 & 220 & 62 & 79 & 9795 & 18065 \\
\hline 1990 & 429 & 238 & 235 & 58 & 72 & 9256 & 16099 \\
\hline 1991 & 387 & 268 & 244 & 69 & 71 & 10037 & 15456 \\
\hline 1992 & 469 & 253 & 259 & 71 & 70 & 10037 & 18048 \\
\hline 1993 & 667 & 239 & 277 & 64 & 73 & 10037 & 17631 \\
\hline 1994 & 911 & 273 & 298 & 54 & 77 & 10100 & 18748 \\
\hline 1995 & 1100 & 252 & 289 & 46 & 80 & 10500 & 19476 \\
\hline 1996 & 906 & 185 & 277 & 48 & 80 & 10500 & 19071 \\
\hline 1997 & 885 & 211 & 275 & 45 & 80 & 10500 & 21281 \\
\hline 1998 & 749 & 240 & 254 & 51 & 78 & 10000 & 19598 \\
\hline 1999 & 929 & 211 & 233 & 60 & 77 & 10000 & 21500 \\
\hline
\end{tabular}

Fonte: As séries referentes à quantidade exportada de madeira serrada de não coníferas $\left(Q_{t}\right)$, quantidade produzida de madeira serrada de não coniferas $\left(Y_{\eta}\right)$; quantidade mundial exportada de madeira serrada de não coníferas $(Y W)$ são da FAO. Esses valores estão expressos em mil $\mathrm{m}^{3}$. Os precos das exportaç̋̃es brasileiras de madeira serrada de não coniferas $\left(P X_{i}\right)$, e das exportaçoes mundiais de madeira serrada de não coníferas $\left(P W_{t}\right)$, expressos em dólares reais, săo medidos pelo valor unitários dessas exportaçées. Os dados utilizados para esses cálculos também são da FAO. O IPA dos Estados Unidos, utilizado para transformar em valores reais as séries de preço é do FMI, disponivel em International Financial Statistics. A série de taxa de câmbio efetiva rea $\left(E_{t}\right)$ foi construida a partir de duas fontes distintas: Almeida (1998) e IPEA. A taxa de utilizaçăo da capacidade $\left(U_{t}\right)$ é a calculada em Castro \& Caval canti (1998) e atualizada pela série da FGV, disponivel em Conjuntura Econômica. 
Tabela 1.3 Dados básicos utilizados nas estimativas das equações de oferta e demanda de exportação de painéis à base de madeira

\begin{tabular}{|c|c|c|c|c|c|c|c|}
\hline Ano & $\boldsymbol{Q}$ & $P X_{t}$ & $P W_{t}$ & $E_{t}$ & $U_{t}$ & $Y_{t}$ & $Y W_{t}$ \\
\hline 1961 & 14 & 222 & 377 & 65 & 93 & 279 & 3158 \\
\hline 1962 & 10 & 327 & 375 & 73 & 91 & 287 & 3601 \\
\hline 1963 & 12 & 296 & 372 & 64 & 84 & 296 & 4026 \\
\hline 1964 & 24 & 290 & 370 & 78 & 81 & 317 & 4907 \\
\hline 1965 & 38 & 340 & 360 & 89 & 79 & 350 & 5489 \\
\hline 1966 & 44 & 444 & 304 & 76 & 80 & 472 & 6260 \\
\hline 1967 & 55 & 355 & 297 & 69 & 81 & 537 & 6878 \\
\hline 1968 & 70 & 454 & 289 & 71 & 86 & 603 & 8286 \\
\hline 1969 & 78 & 717 & 291 & 74 & 89 & 679 & 9228 \\
\hline 1970 & 106 & 577 & 280 & 74 & 91 & 819 & 10006 \\
\hline 1971 & 154 & 465 & 275 & 75 & 94 & 1032 & 10577 \\
\hline 1972 & 172 & 518 & 298 & 77 & 97 & 1390 & 13115 \\
\hline 1973 & 191 & 524 & 332 & 81 & 100 & 1511 & 16064 \\
\hline 1974 & 175 & 466 & 313 & 80 & 97 & 1584 & 13712 \\
\hline 1975 & 185 & 420 & 279 & 84 & 92 & 1725 & 12383 \\
\hline 1976 & 208 & 401 & 288 & 81 & 93 & 1956 & 14559 \\
\hline 1977 & 237 & 369 & 292 & 81 & 88 & 2139 & 14548 \\
\hline 1978 & 300 & 360 & 293 & 85 & 86 & 2218 & 15866 \\
\hline 1979 & 312 & 381 & 323 & 94 & 86 & 2236 & 16789 \\
\hline 1980 & 324 & 386 & 316 & 100 & 89 & 2482 & 15655 \\
\hline 1981 & 374 & 347 & 270 & 85 & 79 & 2576 & 16674 \\
\hline 1982 & 320 & 295 & 252 & 79 & 76 & 2398 & 15544 \\
\hline 1983 & 396 & 274 & 238 & 94 & 72 & 2523 & 16957 \\
\hline 1984 & 453 & 268 & 213 & 86 & 74 & 2512 & 18339 \\
\hline 1985 & 456 & 260 & 218 & 85 & 78 & 2490 & 19223 \\
\hline 1986 & 477 & 275 & 232 & 86 & 83 & 2523 & 20700 \\
\hline 1987 & 464 & 307 & 266 & 88 & 83 & 2758 & 24248 \\
\hline 1988 & 662 & 311 & 267 & 78 & 80 & 2847 & 26670 \\
\hline 1989 & 642 & 260 & 259 & 62 & 79 & 2892 & 29788 \\
\hline 1990 & 616 & 270 & 257 & 58 & 72 & 2892 & 30324 \\
\hline 1991 & 594 & 282 & 263 & 69 & 71 & 2742 & 29750 \\
\hline 1992 & 782 & 283 & 263 & 71 & 70 & 2892 & 33289 \\
\hline 1993 & 1097 & 299 & 276 & 64 & 73 & 3233 & 34990 \\
\hline 1994 & 1223 & 288 & 278 & 54 & 77 & 3538 & 38933 \\
\hline 1995 & 1230 & 293 & 278 & 46 & 80 & 3558 & 41735 \\
\hline 1996 & 1040 & 292 & 255 & 48 & 80 & 3223 & 43051 \\
\hline 1997 & 1095 & 298 & 238 & 45 & 80 & 3223 & 48960 \\
\hline 1998 & 904 & 273 & 215 & 51 & 78 & 3098 & 54755 \\
\hline 1999 & 1396 & 244 & 224 & 60 & 77 & 3098 & 55483 \\
\hline
\end{tabular}

Fonte: As séries referentes à quantidade exportada de painéis à base de madeira $\left(Q_{t}\right)$, quantidade produzida de painéis à base de madeira $\left(Y_{t}\right)$; quantidade mundial exportada de painéis à base de madeira $\left(Y W_{1}\right)$ são da FAO. Esses valores estão expressos em mil $\mathrm{m}^{3}$. Os precos das exportaçes brasileiras de painéis à base de madeira $\left(P X_{t}\right)$, e das exportaçōes mundiais de painéis à base de madeira $\left(P W_{1}\right)$, expressos em dólares reais, são medidos pelo valor unitários dessas exportaçōes. Os dados utilizados para esses cálculos também são da FAO. O IPA dos Estados Unidos, utilizado para transformar em valores reais as séries de preço é do FMI, disponivel em International Financial Statistics. A série de taxa de câmbio efetiva real $\left(E_{t}\right)$ foi construída a partir de duas fontes distintas: Almeida (1998) e IPEA. A taxa de utilização da capacidade $\left(U_{t}\right)$ é a calculada em Castro \& Cavalcanti (1998) e atualizada pela série da FGV, disponivel em Conjuntura Econômica. 
Tabela 1.4 Dados básicos utilizados na estimativa da tendência das exportações de madeira serrada de coníferas

\begin{tabular}{|c|c|c|c|}
\hline Ano & $Q_{t}$ & $V_{t}$ & $W_{t}$ \\
\hline 1961 & 1095 & -26 & 0 \\
\hline 1962 & 825 & -25 & 0 \\
\hline 1963 & 800 & -24 & 0 \\
\hline 1964 & 1055 & -23 & 0 \\
\hline 1965 & 1126 & -22 & 0 \\
\hline 1966 & 1198 & -21 & 0 \\
\hline 1967 & 1034 & -20 & 0 \\
\hline 1968 & 1312 & -19 & 0 \\
\hline 1969 & 1023 & -18 & 0 \\
\hline 1970 & 927 & -17 & 0 \\
\hline 1971 & 994 & -16 & 0 \\
\hline 1972 & 836 & -15 & 0 \\
\hline 1973 & 688 & -14 & 0 \\
\hline 1974 & 384 & -13 & 0 \\
\hline 1975 & 310 & -12 & 0 \\
\hline 1976 & 177 & -11 & 0 \\
\hline 1977 & 192 & -10 & 0 \\
\hline 1978 & 178 & -9 & 0 \\
\hline 1979 & 234 & -8 & 0 \\
\hline 1980 & 187 & -7 & 0 \\
\hline 1981 & 157 & -6 & 0 \\
\hline 1982 & 126 & -5 & 0 \\
\hline 1983 & 114 & -4 & 0 \\
\hline 1984 & 80 & -3 & 0 \\
\hline 1985 & 72 & -2 & 0 \\
\hline 1986 & 81 & -1 & 0 \\
\hline 1987 & 67 & 0 & 0 \\
\hline 1988 & 119 & 0 & 1 \\
\hline 1989 & 114 & 0 & 2 \\
\hline 1990 & 80 & 0 & 3 \\
\hline 1991 & 120 & 0 & 4 \\
\hline 1992 & 250 & 0 & 5 \\
\hline 1993 & 350 & 0 & 6 \\
\hline 1994 & 494 & 0 & 7 \\
\hline 1995 & 496 & 0 & 8 \\
\hline 1996 & 410 & 0 & 9 \\
\hline 1997 & 548 & 0 & 10 \\
\hline 1998 & 677 & 0 & 11 \\
\hline 1999 & 1015 & 0 & 12 \\
\hline
\end{tabular}

Nota: $Q_{t}$ é a quantidade exportada de madeira serrada de coniferas, $W_{t}$ é igual a $Z_{1}\left(X_{t}-\mathrm{K}\right)$ e $V_{1}$ é igual $\left(1-Z_{t}\right)\left(X_{t}-K\right)$. Onde Ké a ano de inflexão, nesse caso $1987 ; X_{\uparrow}$ é a ano de cada observaçào e $Z_{\uparrow}$ é igual a zero quando $X_{\uparrow}$ é menor que $\mathrm{K}$ e igual a um quando $X_{4}$ é maior ou igual a $\mathrm{K}$. 


\section{APÊNDICE 2}

Matrizes de correlação linear simples das variáveis incluídas nas equações de oferta e demanda de exportação de madeira serrada e de painéis à base de madeira 
Quadro 2.1 Matriz de correlação linear simples das variáveis incluídas na equação estrutural de oferta de exportação de madeira serrada de coníferas no período de 1961 a 1987

\begin{tabular}{|l|c|c|c|c|c|}
\hline & $\log P X_{t}$ & $\log E_{t}$ & $\log U_{t}$ & $\log Y_{t}$ & $\log Q_{t-1}$ \\
\hline $\log P X_{t}$ & 1,000 & 0,720 & 0,043 & 0,768 & $-0,713$ \\
\hline $\log E_{t}$ & 0,720 & 1,000 & $-0,234$ & 0,669 & $-0,673$ \\
\hline $\log U_{t}$ & 0,043 & $-0,234$ & 1,000 & $-0,351$ & 0,465 \\
\hline $\log Y_{t}$ & 0,768 & 0,669 & $-0,351$ & 1,000 & $-0,925$ \\
\hline $\log Q_{t-1}$ & $-0,713$ & $-0,673$ & 0,465 & $-0,925$ & 1,000 \\
\hline
\end{tabular}

Nota: As variáveis são definidas no item 3.2 do capítulo 3.

Quadro 2.2 Matriz de correlação linear simples das variáveis incluídas na equação estrutural de demanda de exportação de madeira serrada de coníferas no período de 1961 a 1987

\begin{tabular}{|l|c|c|c|}
\hline & $\log P X_{t} / P W_{t}$ & $\log Y W_{t}$ & $\log Q_{t-1}$ \\
\hline $\log P X_{t} / P W_{t}$ & 1,000 & 0,826 & $-0,858$ \\
\hline $\log Y W_{t}$ & 0,826 & 1,000 & $-0,844$ \\
\hline $\log Q_{t-1}$ & $-0,858$ & $-0,844$ & 1,000 \\
\hline
\end{tabular}

Nota: As variáveis são definidas no item 3.2 do capitulo 3. 
Quadro 2.3 Matriz de correlação linear simples das variáveis incluídas na equação estrutural de oferta de exportação madeira serrada de coníferas no período de 1988 a 1999

\begin{tabular}{|l|c|c|c|c|c|}
\hline & $\log P X_{t}$ & $\log E_{t}$ & $\log U_{t}$ & $\log Y_{t}$ & $\log Q_{t-1}$ \\
\hline $\log P X_{t}$ & 1.000 & 0,244 & 0,263 & 0,269 & $-0,401$ \\
\hline $\log E_{t}$ & 0,244 & 1,000 & $-0,529$ & $-0,189$ & $-0,792$ \\
\hline $\log U_{t}$ & 0,263 & $-0,529$ & 1,000 & 0,203 & 0,470 \\
\hline $\log Y_{t}$ & 0,269 & $-0,189$ & 0,203 & 1,000 & 0,482 \\
\hline $\log Q_{t-1}$ & $-0,401$ & $-0,792$ & 0,470 & 0,482 & 1,000 \\
\hline
\end{tabular}

Nota: As variáveis são definidas no item 3.2 do capítulo 3.

Quadro 2.4 Matriz de correlação linear simples das variáveis incluídas na equação estrutural de demanda de exportação de madeira serrada de coníferas no período de 1988 a 1999

\begin{tabular}{|l|c|c|c|}
\hline & $\log P X_{t} / P W_{t}$ & $\log Y W_{t}$ & $\log Q_{t-1}$ \\
\hline $\log P X_{t} / P W_{t}$ & 1,000 & $-0,333$ & 0,919 \\
\hline $\log Y W_{t}$ & $-0,333$ & 1,000 & $-0,506$ \\
\hline $\log Q_{t-1}$ & 0,919 & $-0,506$ & 1,000 \\
\hline
\end{tabular}

Nota: As variáveis são definidas no item 3.2 do capítulo 3 . 
Quadro 2.5 Matriz de correlação linear simples das variáveis incluídas na equação estrutural de oferta de exportação de madeira serrada de não coníferas no período de 1970 a 1999

\begin{tabular}{|l|c|c|c|c|c|}
\hline & $\log P X_{t}$ & $\log E_{t}$ & $\log U_{t}$ & $\log Y_{t}$ & $\log Q_{t-1}$ \\
\hline $\log P X_{t}$ & 1,000 & $-0,004$ & $-0,625$ & 0,726 & 0,526 \\
\hline $\log E_{t}$ & $-0,004$ & 1,000 & 0,324 & $-0,384$ & $-0,514$ \\
\hline $\log U_{t}$ & $-0,625$ & 0,324 & 1,000 & $-0,866$ & $-0,593$ \\
\hline $\log Y_{t}$ & 0,726 & $-0,384$ & $-0,866$ & 1,000 & 0,826 \\
\hline $\log Q_{t-1}$ & 0,526 & $-0,514$ & $-0,593$ & 0,826 & 1,000 \\
\hline
\end{tabular}

Nota: As variáveis são definidas no item 3.2 do capítulo 3.

Quadro 2.6 Matriz de correlação linear simples das variáveis incluídas na equação estrutural de demanda de exportação de madeira serrada de não coníferas no período de 1970 a 1999

\begin{tabular}{|l|c|c|c|}
\hline & $\log P X_{t} / P W_{t}$ & $\log Y W_{t}$ & $\log Q_{t-1}$ \\
\hline $\log P X_{t} / P W_{t}$ & 1,000 & $-0,215$ & 0,833 \\
\hline $\log Y W_{t}$ & $-0,215$ & 1,000 & $-0,165$ \\
\hline $\log Q_{t-1}$ & 0,833 & $-0,165$ & 1,000 \\
\hline
\end{tabular}

Nota: As variáveis são definidas no item 3.2 do capítulo 3 . 
Quadro 2.7 Matriz de correlação linear simples das variáveis incluídas na equação estrutural de oferta de exportação de painéis à base de madeira no período de 1961 a 1999

\begin{tabular}{|l|c|c|c|c|c|}
\hline & $\log P X_{t}$ & $\log E_{t}$ & $\log U_{t}$ & $\log Y_{t}$ & $\log Q_{t-1}$ \\
\hline $\log P X_{t}$ & 1,000 & 0,304 & 0,766 & $-0,417$ & $-0,438$ \\
\hline $\log E_{t}$ & 0,304 & 1,000 & 0,289 & $-0,214$ & $-0,370$ \\
\hline $\log U_{t}$ & 0,766 & 0,289 & 1,000 & $-0,358$ & $-0,416$ \\
\hline $\log Y_{t}$ & $-0,417$ & $-0,214$ & $-0,358$ & 1,000 & 0,976 \\
\hline $\log Q_{t-1}$ & $-0,438$ & $-0,370$ & $-0,416$ & 0,976 & 1,000 \\
\hline
\end{tabular}

Nota: As variáveis são definidas no item 3.2 do capítulo 3.

Quadro 2.8 Matriz de correlação linear simples das variáveis incluídas na equação estrutural de demanda de exportação de painéis à base de madeira no período de 1961 a 1999

\begin{tabular}{|l|c|c|c|}
\hline & $\log P X_{t} / P W_{t}$ & $\log Y W_{t}$ & $\log Q_{t-1}$ \\
\hline $\log P X_{t} / P W_{t}$ & 1,000 & $-0,053$ & 0,971 \\
\hline $\log Y W_{t}$ & $-0,053$ & 1,000 & $-0,001$ \\
\hline $\log Q_{t-1}$ & 0,971 & $-0,001$ & 1,000 \\
\hline
\end{tabular}

Nota: As variáveis são definidas no item 3.2 do capítulo 3 . 
APÊNDICE 3

Algumas estimativas testadas das equações de oferta e demanda de exportação de madeira serrada e de painéis à base de madeira 
Tabela 3.1 Estimativa das equações estruturais da oferta de exportação de madeira serrada de coníferas sem a variável $E_{t}$

\begin{tabular}{|c|c|c|c|c|c|c|c|}
\hline \multirow{2}{*}{ Período } & \multicolumn{5}{|c|}{ Variáveis } & \multirow{2}{*}{$\mathbf{R}^{2}$} & \multirow{2}{*}{$\mathbf{F}$} \\
\hline & Constante & $\mathrm{PX}_{\mathrm{t}}$ & $\mathrm{U}_{\mathrm{t}}$ & $Y_{t}$ & $\mathrm{Q}_{\mathrm{t}-1}$ & & \\
\hline \multirow[b]{2}{*}{1961 a 1987} & 7,824 & $-0,011$ & $-0,739$ & $-0,252$ & 0,947 & 0,962 & 132,278 \\
\hline & $(1,174)^{\mathrm{ns}}$ & $(-0,041)^{\mathrm{ns}}$ & $(-0,909)^{\mathrm{ns}}$ & $(-0,736)^{n s}$ & $(7,018)^{\mathrm{a}}$ & & \\
\hline \multirow{2}{*}{1988 a 1999} & $-619,051$ & $-8,018$ & 11,803 & 39,376 & $-0,498$ & 0,452 & 1,444 \\
\hline & $(-0,359)^{\mathrm{ns}}$ & $(-0,264)^{\mathrm{ns}}$ & $(0,240)^{\mathrm{ns}}$ & $(0,363)^{\mathrm{ns}}$ & $(-0,101)^{\mathrm{ns}}$ & & \\
\hline
\end{tabular}

Notas: Os números entre parênteses sob os coeficientes são as estatísticas $t$, onde "a" representa significativo ao nível de 1\% e "ns" não significativo. As variáveis são definidas no item 3.2 do capítulo 3 .

Tabela 3.2 Estimativa das equações estruturais da demanda de exportação de madeira serrada de coníferas sem a variável $E_{t}$

\begin{tabular}{|c|c|c|c|c|c|c|}
\hline \multirow{2}{*}{ Período } & \multicolumn{4}{|c|}{ Variáveis } & \multirow{2}{*}{$\mathbf{R}^{2}$} & \multirow{2}{*}{$\mathbf{F}$} \\
\hline & Constante & $\mathrm{PX}_{\mathrm{t}} / \mathrm{PW}_{\mathrm{t}}$ & $\mathrm{YW}_{\mathrm{t}}$ & $Q_{t-1}$ & & \\
\hline \multirow{2}{*}{1961 a 1987} & $-3,179$ & $-0,611$ & 0,278 & 0,885 & 0,974 & 273,424 \\
\hline & $(-0,433)^{\mathrm{ns}}$ & $(-1,662)^{\mathrm{c}}$ & $(0,689)^{\mathrm{ns}}$ & $(9,346)^{a}$ & & \\
\hline \multirow{2}{*}{1988 a 1999} & $-15,349$ & 0,952 & 0,910 & 0,891 & 0,881 & 19,823 \\
\hline & $(-0,415)^{\mathrm{ns}}$ & $(1,025)^{\mathrm{ns}}$ & $(0,400)^{\mathrm{ns}}$ & $(2,291)^{b}$ & & \\
\hline
\end{tabular}

Notas: Os números entre parênteses sob os coeficientes são as estatísticas $t$, onde "a" representa significativo ao nível de $1 \%$, "b" significativo ao nível de $10 \%$, "c" significativo ao nível de $20 \%$ e "ns" não significativo. As variáveis são definidas no item 3.2 do capítulo 3. 
Tabela 3.3 Estimativa das equações estruturais da oferta de exportação de madeira serrada de coníferas sem a variável $U_{t}$

\begin{tabular}{|c|c|c|c|c|c|c|c|}
\hline \multirow{2}{*}{ Período } & \multicolumn{5}{|c|}{ Variáveis } & \multirow{2}{*}{$\mathbf{R}^{2}$} & \multirow{2}{*}{$\mathbf{F}$} \\
\hline & Constante & $\mathrm{PX}_{\mathrm{t}}$ & $E_{t}$ & $Y_{t}$ & $\mathrm{Q}_{\mathrm{t}-1}$ & & \\
\hline \multirow{2}{*}{$\begin{array}{l}1961 \text { a } \\
1987\end{array}$} & 2,837 & $-0,290$ & 0,570 & $-0,172$ & 0,905 & \multirow[t]{2}{*}{0,970} & \multirow[t]{2}{*}{167,612} \\
\hline & $(0,453)^{\mathrm{ns}}$ & $(-1,367)^{\mathfrak{c}}$ & $(0,910)^{\mathrm{ns}}$ & $(-0,563)^{\mathrm{ns}}$ & $(8,540)^{\mathrm{a}}$ & & \\
\hline \multirow{2}{*}{$\begin{array}{l}1988 \text { a } \\
1999\end{array}$} & $-91,826$ & 0,842 & 1,665 & 4,922 & 1,193 & \multirow[t]{2}{*}{0,957} & \multirow[t]{2}{*}{38,507} \\
\hline & $(-1,040)^{\mathrm{ns}}$ & $(-0,689)^{\mathrm{ns}}$ & $(1,967)^{\mathrm{b}}$ & $(0,793)^{\mathrm{ns}}$ & $(4,093)^{a}$ & & \\
\hline
\end{tabular}

Notas: Os números entre parênteses sob os coeficientes são as estatísticas $t$, onde "a" representa significativo ao nível de $1 \%$, "b" significativo ao nível de $10 \%$, "c" significativo ao nível de $20 \%$ e "ns" não significativo. As variáveis são definidas no item 3.2 do capitulo 3.

Tabela 3.4 Estimativa das equações estruturais da demanda de exportação de madeira serrada de coníferas sem a variável $U_{t}$

\section{Variáveis}

Período

\begin{tabular}{ccccccc}
\cline { 1 - 4 } Constante & $\mathrm{PX}_{\mathrm{t}} / \mathrm{PW}_{\mathrm{t}}$ & $\mathrm{YW}_{\mathrm{t}}$ & $\mathrm{Q}_{\mathrm{t}-1}$ & & $\mathbf{R}$ & \\
& & & & & \\
\hline$-3,544$ & $-0,655$ & 0,306 & 0,877 & 0,974 & 278,968
\end{tabular}

1961 a 1987

$$
(-0,486)^{\mathrm{ns}} \quad(-1,787)^{\mathrm{c}} \quad(0,763)^{\mathrm{ns}} \quad(9,323)^{\mathrm{a}}
$$

1988 a 1999

$\begin{array}{llllll}-14,037 & 1,030 & 0,823 & 0,911 & 0,881 & 19,823\end{array}$

$$
(-0,377)^{\mathrm{ns}} \quad(1,086)^{\mathrm{ns}} \quad(0,359)^{\mathrm{ns}} \quad(2,315)^{\mathrm{b}}
$$

Notas: Os números entre parênteses sob os coeficientes são as estatísticas $t$, onde "a" representa significativo ao nível de $1 \%$, "b" significativo ao nível de $5 \%$, "c" significativo ao nível de $10 \%$ e "ns" não significativo. As variáveis são definidas no item 3.2 do capitulo 3. 
Tabela 3.5 Estimativa das equações estruturais da oferta de exportação de madeira serrada de coníferas sem a variável $Y_{t}$

\begin{tabular}{|c|c|c|c|c|c|c|c|}
\hline \multirow{2}{*}{ Período } & \multicolumn{5}{|c|}{ Variáveis } & \multirow{2}{*}{$\mathbf{R}^{2}$} & \multirow{2}{*}{$\mathbf{F}$} \\
\hline & Constante & $\mathrm{PX}_{\mathrm{t}}$ & $\mathrm{E}_{\mathrm{t}}$ & $\mathrm{U}_{\mathrm{t}}$ & $\mathrm{Q}_{\mathrm{t}-1}$ & & \\
\hline \multirow[b]{2}{*}{1961 a 1987} & 2,517 & $-0,019$ & 0,144 & $-0,852$ & 1,049 & 0,961 & 129,421 \\
\hline & $(0,546)^{\mathrm{ns}}$ & $(-0,049)^{\mathrm{ns}}$ & $(0,172)^{\mathrm{ns}}$ & $(-0,853)^{\mathrm{ns}}$ & $(8,463)^{\mathrm{a}}$ & & \\
\hline \multirow[b]{2}{*}{1988 a 1999} & $-13,521$ & $-5,232$ & 2,095 & 8,359 & 0,690 & 0,245 & 0,569 \\
\hline & $(-0,381)^{\mathrm{ns}}$ & $(-0,258)^{\mathrm{ns}}$ & $(0,767)^{\mathrm{ns}}$ & $(0,255)^{\mathrm{ns}}$ & $(0,314)^{\mathrm{ns}}$ & & \\
\hline
\end{tabular}

Tabela 3.6 Estimativa das equações estruturais da demanda de exportação de madeira serrada de coníferas sem a variável $Y_{t}$

\section{Variáveis}

Periodo

\begin{tabular}{ccccccc}
\hline Constante & $\mathrm{PX}_{\mathrm{t}} / \mathrm{PW}_{\mathrm{t}}$ & $\mathrm{YW}_{\mathrm{t}}$ & $\mathrm{Q}_{\mathrm{t}-1}$ & & $\mathbf{R}$ \\
\hline$-2,902$ & $-0,577$ & 0,257 & 0,891 & 0,973 & 268,709
\end{tabular}

1961 a 1987

$$
(-0,341)^{\text {ns }} \quad(-0,920)^{\text {ns }} \quad(0,498)^{\text {ns }} \quad(6,834)^{\mathrm{a}}
$$

1988 a 1999

$\begin{array}{llllll}-46,024 & -0,867 & 2,938 & 0,425 & 0,826 & 12,702\end{array}$

$$
(-0,958)^{\mathrm{ns}} \quad(-0,566)^{\mathrm{ns}} \quad(0,985)^{\mathrm{ns}} \quad(0,786)^{\mathrm{ns}}
$$

Notas: Os números entre parênteses sob os coeficientes são as estatísticas $t$, onde "a" representa significativo ao nível de $1 \%$ e "ns" não significativo. As variáveis são definidas no item 3.2 do capitulo 3. 
Tabela 3.7 Estimativa das equações estruturais da oferta de exportação de madeira serrada de coníferas sem as variável $E_{t}$ e $U_{t}$

\begin{tabular}{|c|c|c|c|c|c|c|}
\hline \multirow{2}{*}{ Período } & \multicolumn{4}{|c|}{ Variáveis } & \multirow{2}{*}{$\mathbf{R}^{2}$} & \multirow{2}{*}{$\mathbf{F}$} \\
\hline & Constante & $\mathrm{PX}_{\mathrm{t}}$ & $Y_{t}$ & $\mathrm{Q}_{\mathrm{t}-1}$ & & \\
\hline \multirow[b]{2}{*}{1961 a 198} & 5,447 & $-0,203$ & 0,192 & 0,884 & 0,966 & 209,828 \\
\hline & $(0,957)^{\mathrm{ns}}$ & $(-1,083)^{\mathrm{ns}}$ & $(-0,614)^{\mathrm{ns}}$ & $(8,293)^{\mathrm{a}}$ & & \\
\hline \multirow{2}{*}{1988 a 19} & $-6,542$ & 3,403 & $-0,807$ & 1,160 & 0,715 & 6,679 \\
\hline & $(-0,026)^{\mathrm{ns}}$ & $(0,741)^{\mathrm{ns}}$ & $(-0,046)^{n s}$ & $(2,046)^{b}$ & & \\
\hline
\end{tabular}

Tabela 3.8 Estimativa das equações estruturais da demanda de exportação de madeira serrada de coníferas sem as variável $E_{t}$ e $U_{t}$

\begin{tabular}{|c|c|c|c|c|c|c|}
\hline \multirow{2}{*}{ Período } & \multicolumn{4}{|c|}{ Variáveis } & \multirow{2}{*}{$\mathbf{R}^{2}$} & \multirow{2}{*}{$\mathbf{F}$} \\
\hline & Constante & $\mathrm{PX}_{\mathrm{t}} / \mathrm{PW}_{\mathrm{t}}$ & $Y W_{t}$ & $Q_{t-1}$ & & \\
\hline \multirow{2}{*}{1961 a 19} & $-4,318$ & $-0,749$ & 0,365 & 0,861 & 0,975 & 268,709 \\
\hline & $(-0,599)^{\mathrm{ns}}$ & $(-2,027)^{c}$ & $(0,916)^{n s}$ & $(9,185)^{\mathrm{a}}$ & & \\
\hline \multirow{2}{*}{1988 a 19} & 11,203 & 2,527 & $-0,845$ & 1,294 & 0,826 & 12,702 \\
\hline & $(0,220)^{\mathrm{ns}}$ & $(1,668)^{d}$ & $(-0,268)^{n s}$ & $(2,310)^{b}$ & & \\
\hline
\end{tabular}


Tabela 3.9 Estimativa das equações estruturais da oferta de exportação de madeira serrada de coníferas sem as variável $E_{t}$ e $Y_{t}$

\section{Variáveis}

Período

\begin{tabular}{cccccc}
\cline { 1 - 4 } Constante & $\mathrm{PX}_{\mathrm{t}}$ & $\mathrm{U}_{\mathrm{t}}$ & $\mathrm{Q}_{\mathrm{t}-1}$ & $\mathbf{R}^{2}$ & $\mathbf{F}$ \\
\hline 3,197 & 0,023 & $-0,929$ & 1,055 & 0,959 & 209,828
\end{tabular}

1961 a 1987

\begin{tabular}{llllll}
$(1,343)^{\text {ns }}$ & $(0,080)^{\text {ns }}$ & $(-1,076)^{\text {ns }}$ & $(8,959)^{\mathrm{a}}$ & & \\
\hline 4,786 & $-7,560$ & 10,518 & 0,118 & $-0,411$ & $-0,777$
\end{tabular}

1988 a 1999

$$
(0,152)^{\text {ns }} \quad(-0,270)^{\text {ns }} \quad(0,238)^{\text {ns }} \quad(0,037)^{\text {ns }}
$$

Notas: Os números entre parênteses sob os coeficientes são as estatísticas $t$, onde "a" representa significativo ao nível de $1 \%$ e "ns" não significativo. As variáveis são definidas no item 3.2 do capítulo 3 .

Tabela 3.10 Estimativa das equações estruturais da demanda de exportação de madeira serrada de coníferas sem as variável $E_{t}$ e $Y_{t}$

\section{Variáveis}

Período

\begin{tabular}{ccccccc} 
Constante & $\mathrm{PX}_{\mathfrak{t}} / \mathrm{PW}_{\mathrm{t}}$ & $\mathrm{YW}_{\mathrm{t}}$ & $\mathrm{Q}_{\mathrm{t}-1}$ & & $\mathbf{R}^{2}$ & $\mathbf{F}$ \\
\hline$-4,204$ & $-0,735$ & 0,356 & 0,863 & 0,975 & 286,305
\end{tabular}

1961 a 1987

$$
(-0,493)^{\mathrm{ns}} \quad(-1,110)^{\mathrm{ns}} \quad(0,675)^{\mathrm{ns}} \quad(6,422)^{\mathrm{a}}
$$

1988 a 1999

$\begin{array}{llllll}-48,892 & -1,037 & 3,127 & 0,382 & 0,813 & 11,587\end{array}$

$$
(-0,979)^{\text {ns }} \quad(-0,650)^{\text {ns }} \quad(1,008)^{\text {ns }} \quad(0,678)^{\text {ns }}
$$

Notas: Os números entre parênteses sob os coeficientes são as estatísticas $t$, onde "a" representa significativo ao nível de $1 \% \mathrm{e}$ "ns" não significativo. As variáveis são definidas no item 3.2 do capítulo 3 . 
Tabela 3.11 Estimativa das equações estruturais da oferta de exportação de madeira serrada de coníferas sem as variável $U_{t}$ e $Y_{t}$

\begin{tabular}{|c|c|c|c|c|c|c|}
\hline \multirow{2}{*}{ Período } & \multicolumn{4}{|c|}{ Variáveis } & \multirow{2}{*}{$\mathbf{R}^{2}$} & \multirow{2}{*}{$\mathbf{F}$} \\
\hline & Constante & $\mathrm{PX}_{\mathrm{t}}$ & $\mathrm{E}_{\mathrm{t}}$ & $Q_{t-1}$ & & \\
\hline \multirow{2}{*}{1961 a 198} & $-0,313$ & $-0,288$ & 0,511 & 0,963 & 0,969 & 229,249 \\
\hline & $(-0,113)^{\mathrm{ns}}$ & $(-1,433)^{\mathrm{c}}$ & $(0,814)^{\mathrm{ns}}$ & $(15,412)^{\mathrm{a}}$ & & \\
\hline \multirow{2}{*}{1988 a 19} & $-10,262$ & $-0,020$ & 1,877 & 1,240 & 0,919 & 30,378 \\
\hline & $(-0,633)^{\mathrm{ns}}$ & $(-0,009)^{\mathrm{ns}}$ & $(2,247)^{\mathbf{b}}$ & $(4,729)^{\mathrm{a}}$ & & \\
\hline
\end{tabular}

Tabela 3.12 Estimativa das equações estruturais da demanda de exportação de madeira serrada de coníferas sem as variável $U_{t}$ e $Y_{t}$

\section{Variáveis}

Período

\begin{tabular}{cccccc}
\hline Constante & $\mathrm{PX}_{\sqrt{ }} / \mathrm{PW}_{\mathrm{t}}$ & $\mathrm{YW}_{\mathrm{t}}$ & $\mathrm{Q}_{\mathrm{t}-1}$ & & $\mathbf{R}$ \\
\hline$-2,971$ & $-0,586$ & 0,263 & 0,890 & 0,974 & 269,940
\end{tabular}

1961 a 1987

\begin{tabular}{llllll}
$(-0,350)^{\text {ns }}$ & $(-0,936)^{\text {ns }}$ & $(0,509)^{\text {ns }}$ & $(6,837)^{\mathrm{a}}$ & & \\
\hline$-59,367$ & $-1,659$ & 3,820 & 0,223 & 0,751 & 8,046
\end{tabular}

1988 a 1999

$$
(-0,888)^{\mathrm{ns}} \quad(-0,609)^{\mathrm{ns}} \quad(0,905)^{\mathrm{ns}} \quad(0,269)^{\mathrm{ns}}
$$

Notas: Os números entre parênteses sob os coeficientes são as estatísticas $t$, onde "a" representa significativo ao nível de $1 \%$ e "ns" não significativo. As variáveis são definidas no item 3.2 do capítulo 3 . 
Tabela 3.13 Estimativa da equação estrutural da oferta de exportação de madeira serrada de não coníferas com a inclusão da variável $U_{t}$ para o período de 1970 a 1999

\begin{tabular}{|c|c|c|c|c|c|c|c|}
\hline \multirow[b]{2}{*}{ Constante } & \multicolumn{5}{|c|}{ Variáveis } & \multirow{2}{*}{$\mathbf{R}^{2}$} & \multirow{2}{*}{$\mathbf{F}$} \\
\hline & $\mathrm{PX}_{\mathrm{t}}$ & $E_{t}$ & $\mathrm{U}_{\mathrm{t}}$ & $Y_{t}$ & $Q_{t-1}$ & & \\
\hline$-2,696$ & 1,692 & $-0,720$ & 1,058 & $-0,149$ & 0,569 & 0,789 & 17,907 \\
\hline$(-0,290)$ & $(2,044)^{c}$ & $(-2,170)^{b}$ & $(0,983)^{b}$ & $(-0,281)^{\mathrm{ns}}$ & $(3,112)^{\mathbf{a}}$ & & \\
\hline
\end{tabular}

Notas: Os números entre parênteses sob os coeficientes são as estatísticas $t$, onde "a" representa significativo ao nível de $1 \%$, "b" significativo ao nível de $5 \%$, "c" significativo ao nível de $10 \%$ e "ns" não significativo. As variáveis são definidas no item 3.2 do capítulo 3 .

Tabela 3.14 Estimativa da equação estrutural da demanda de exportação de madeira serrada de não coníferas com a inclusão da variável $U_{t}$ para o período de 1970 a 1999

\begin{tabular}{ccccccc}
\hline \multicolumn{3}{c}{ Variáveis } & & $\mathbf{R}^{2}$ & $\mathbf{F}$ \\
\hline Constante & $\mathrm{PX}_{\mathrm{t}} / \mathrm{PW}_{\mathrm{t}}$ & $\mathrm{YW}_{\mathrm{t}}$ & $\mathrm{Q}_{\mathrm{t}-1}$ & & \\
\hline$-6,036$ & $-0,182$ & 0,836 & 0,412 & 0,878 & 62,269 \\
$(-2,553)^{\mathrm{a}}$ & $(-0,809)^{\mathrm{ns}}$ & $(4,029)^{\mathrm{a}}$ & $(3,704)^{\mathrm{a}}$ & & \\
& & & & &
\end{tabular}

Notas: Os números entre parênteses sob os coeficientes são as estatísticas $t$, onde "a" representa significativo ao nível de $1 \%$ e "ns" não significativo. As variáveis são definidas no item 3.2 do capítulo 3. 
Tabela 3.15 Estimativa da equação estrutural da oferta de exportação de madeira serrada de não coníferas para o período de 1970 a 1999 utilizando a taxa de câmbio real bilateral $\left(E_{t}^{*}\right)$

\begin{tabular}{|c|c|c|c|c|c|c|}
\hline \multicolumn{5}{|c|}{ Variáveis } & \multirow{2}{*}{$\mathbf{R}^{2}$} & \multirow{2}{*}{$\mathbf{F}$} \\
\hline Constante & $\mathrm{PX}_{\mathrm{t}}$ & $\mathrm{E}_{\mathrm{t}}^{*}$ & $Y_{t}$ & $Q_{t-1}$ & & \\
\hline 3,943 & 1,345 & $-0,438$ & $-0,322$ & 0,682 & 0,789 & 23,389 \\
\hline$(1,527)^{\mathrm{c}}$ & $(1,779)^{\mathrm{b}}$ & $(-1,697)^{\mathrm{c}}$ & $(-0,859)^{\mathrm{ns}}$ & $(4,215)^{\mathrm{a}}$ & & \\
\hline
\end{tabular}

Notas: Os números entre parênteses sob os coeficientes são as estatísticas $t$, onde "a" representa significativo ao nível de $1 \%$, "b" significativo ao nível de $10 \%$, "c" significativo ao nível de $15 \%$ e "ns" não significativo. As variáveis são definidas no item 3.2 do capítulo 3 .

Tabela 3.16 Estimativa da equação estrutural da demanda de exportação de madeira serrada de não coníferas para o período de 1970 a 1999 utilizando a taxa de câmbio real bilateral $\left(E_{t}^{*}\right)$

\begin{tabular}{|c|c|c|c|c|c|}
\hline \multicolumn{4}{|c|}{ Variáveis } & \multirow{2}{*}{$\mathbf{R}^{2}$} & \multirow{2}{*}{$\mathbf{F}$} \\
\hline Constante & $\mathrm{PX}_{\mathrm{t}} / \mathrm{PW}_{\mathrm{t}}$ & $\mathrm{YW}_{\mathrm{t}}$ & $Q_{t-1}$ & & \\
\hline$-6,037$ & $-0,181$ & 0,836 & 0,412 & 0,878 & 62,278 \\
\hline$(-2,550)^{b}$ & $(-0,783)^{\mathrm{ns}}$ & $(4,026)^{a}$ & $(3,704)^{\mathrm{a}}$ & & \\
\hline
\end{tabular}


Tabela 3.17 Estimativa da equação estrutural da oferta de exportação de madeira serrada de não coníferas para o período de 1970 a 1999 utilizando a taxa de câmbio efetiva real com um ano de defasagem $\left(E_{t-1}\right)$

\begin{tabular}{cccccccc}
\hline \multicolumn{5}{c}{ Variáveis } & $\mathbf{R}^{2}$ & $\mathbf{F}$ \\
\cline { 1 - 5 } Constante & $\mathrm{PX}_{\mathrm{t}}$ & $\mathrm{E}_{\mathrm{t}-1}$ & $\mathrm{Y}_{\mathrm{t}}$ & $\mathrm{Q}_{\mathrm{t}-1}$ & & \\
\hline$-4,616$ & 0,115 & $-0,518$ & 0,414 & 0,974 & 0,896 & 53,637 \\
$(-0,452)^{\mathrm{ns}}$ & $(0,148)^{\mathrm{ns}}$ & $(-0,705)^{\mathrm{ns}}$ & $(0,968)^{\mathrm{ns}}$ & $(7,145)^{\mathrm{a}}$ & &
\end{tabular}

Notas: Os números entre parênteses sob os coeficientes são as estatísticas $t$, onde "a" representa significativo ao nível de $1 \%$ e "ns" não significativamente diferente de zero. As variáveis são definidas no item 3.2 do capítulo 3.

Tabela 3.18 Estimativa da equação estrutural da demanda de exportação de madeira serrada de não coníferas para o período de 1970 a 1999 utilizando a taxa de câmbio efetiva real com um ano de defasagem $\left(E_{t-1}\right)$

\begin{tabular}{ccccccc}
\hline & \multicolumn{3}{c}{ Variáveis } & & $\mathbf{R}^{2}$ & $\mathbf{F}$ \\
\hline Constante & $\mathrm{PX}_{\mathrm{t}} / \mathrm{PW}_{\mathrm{t}}$ & $\mathrm{YW}_{\mathrm{t}}$ & $\mathrm{Q}_{\mathrm{t}-1}$ & & \\
\hline$-6,616$ & $-0,325$ & 0,444 & 0,903 & 0,917 & 95,861 \\
$(-0,770)^{\mathrm{ns}}$ & $(-0,814)^{\mathrm{ns}}$ & $(1,074)^{\mathrm{ns}}$ & $(9,500)^{\mathrm{a}}$ & &
\end{tabular}

Notas: Os números entre parênteses sob os coeficientes são as estatísticas $t$, onde "a" representa significativo ao nível de $1 \% \mathrm{e} \mathrm{"ns"} \mathrm{não} \mathrm{significativo.} \mathrm{As} \mathrm{variáveis} \mathrm{são} \mathrm{definidas} \mathrm{no} \mathrm{item} 3.2$ do capitulo 3 . 
Tabela 3.19 Estimativa da equação estrutural da oferta de exportação de madeira serrada de não coníferas para o período de 1970 a 1999 utilizando a taxa de câmbio efetiva real com dois anos de defasagem $\left(E_{t-2}\right)$

\begin{tabular}{cccccccc}
\hline \multicolumn{5}{c}{ Variáveis } & $\mathbf{R}^{2}$ & $\mathbf{F}$ \\
\hline Constante & $\mathrm{PX}_{\mathrm{t}}$ & $\mathrm{E}_{\mathrm{t}-2}$ & $\mathrm{Y}_{\mathrm{t}}$ & $\mathrm{Q}_{\mathrm{t}-1}$ & & \\
\hline 5,459 & 1,864 & $-0,774$ & $-0,502$ & 0,678 & 0,776 & 21,684 \\
$(1,974)^{\mathrm{c}}$ & $(2,097)^{\mathrm{b}}$ & $(-2,421)^{\mathrm{b}}$ & $(-1,213)^{\mathrm{ns}}$ & $(4,220)^{\mathrm{a}}$ & & & \\
\hline
\end{tabular}

Notas: Os números entre parênteses sob os coeficientes são as estatísticas $t$, onde "a" representa significativo ao nível de $1 \%$, "b" significativo ao nível de $5 \%$, "c" significativo ao nível de $10 \%$ e "ns" não significativamente diferente de zero. As variáveis são definidas no item 3.2 do capítulo 3.

Tabela 3.20 Estimativa da equação estrutural da demanda de exportação de madeira serrada de não coníferas para o período de 1970 a 1999 utilizando a taxa de câmbio efetiva real com dois anos de defasagem $\left(E_{t-2}\right)$

\begin{tabular}{ccccccc}
\hline \multicolumn{3}{c}{ Variáveis } & & $\mathbf{R}^{2}$ & $\mathbf{F}$ \\
\cline { 1 - 5 } Constante & $\mathrm{PX}_{\mathrm{t}} / \mathrm{PW}_{\mathrm{t}}$ & $\mathrm{YW}_{\mathrm{t}}$ & $\mathrm{Q}_{\mathrm{t}-1}$ & & \\
\hline$-5,900$ & $-0,240$ & 0,827 & 0,413 & 0,876 & 60,971 \\
$(-2,470)^{\mathrm{b}}$ & $(-1,038)^{\mathrm{ns}}$ & $(3,947)^{\mathrm{a}}$ & $(3,677)^{\mathrm{a}}$ & & & \\
\hline
\end{tabular}

Notas: Os números entre parênteses sob os coeficientes são as estatísticas $t$, onde "a" representa significativo ao nivel de $1 \%$, "b" significativo ao nivel de $5 \%$ e "ns" não significativo. As variáveis são definidas no item 3.2 do capítulo 3. 
Tabela 3.21 Estimativa da equação estrutural da oferta de exportação de madeira serrada de não coníferas para o período de 1970 a 1999 utilizando a taxa de câmbio efetiva real com três anos de defasagem $\left(E_{t-3}\right)$

\begin{tabular}{cccccccc}
\hline \multicolumn{5}{c}{ Variáveis } & & $\mathbf{R}^{2}$ & $\mathbf{F}$ \\
\hline Constante & $\mathrm{PX}_{\mathrm{t}}$ & $\mathrm{E}_{\mathrm{t}-3}$ & $\mathrm{Y}_{\mathrm{t}}$ & $\mathrm{Q}_{\mathrm{t}-1}$ & & \\
\hline 4,812 & 1,774 & $-0,824$ & $-0,404$ & 0,663 & 0,785 & 21,684 \\
$(1,865)^{\mathrm{c}}$ & $(1,823)^{\mathrm{c}}$ & $(-2,433)^{\mathrm{b}}$ & $(-0,936)^{\mathrm{ns}}$ & $(4,146)^{\mathrm{a}}$ & & \\
\hline
\end{tabular}

Notas: Os números entre parênteses sob os coeficientes são as estatísticas $t$, onde "a" representa significativo ao nível de $1 \%$, "b" significativo ao nível de $5 \%$, "c" significativo ao nível de $10 \%$ e "ns" não significativamente diferente de zero. As variáveis são definidas no item 3.2 do capítulo 3 .

Tabela 3.22 Estimativa da equação estrutural da demanda de exportação de madeira serrada de não coníferas para o período de 1970 a 1999 utilizando a taxa de câmbio efetiva real com três anos de defasagem $\left(E_{t-3}\right)$

\begin{tabular}{ccccccc}
\hline \multicolumn{3}{c}{ Variáveis } & \multirow{2}{*}{$\mathbf{R}^{2}$} & $\mathbf{F}$ \\
\cline { 1 - 4 } Constante & $\mathrm{PX}_{\mathrm{t}} / \mathrm{PW}_{\mathrm{t}}$ & $\mathrm{YW}_{\mathrm{t}}$ & $\mathrm{Q}_{\mathrm{t}-1}$ & & \\
\hline$-5,741$ & $-0,308$ & 0,817 & 0,414 & 0,872 & 58,927 \\
$(-2,365)^{\mathrm{b}}$ & $(-1,281)^{\mathrm{ns}}$ & $(3,837)^{\mathrm{a}}$ & $(3,632)^{\mathrm{a}}$ & & & \\
\end{tabular}

Notas: Os números entre parênteses sob os coeficientes são as estatísticas $t$, onde "a" representa significativo ao nível de $1 \%$ " $b$ " significativo ao nível de $5 \%$ e "ns" não significativo. As variáveis são definidas no item 3.2 do capítulo 3. 
Tabela 3.23 Estimativa da equação estrutural da oferta de exportação de madeira serrada de não coníferas para o período de 1970 a 1999 utilizando a taxa de câmbio efetiva real com quatro anos de defasagem $\left(E_{t-4}\right)$

\begin{tabular}{cccccccc}
\hline \multicolumn{5}{c}{ Variáveis } & \multirow{2}{*}{$\mathbf{R}^{2}$} & $\mathbf{F}$ \\
\hline Constante & $\mathrm{PX}_{\mathrm{t}}$ & $\mathrm{E}_{\mathrm{t}-4}$ & $\mathrm{Y}_{\mathrm{t}}$ & $\mathrm{Q}_{\mathrm{t}-1}$ & & \\
\hline 4,145 & 1,438 & $-0,880$ & $-0,177$ & 0,597 & & 0,819 & 28,275 \\
$(1,820)^{\mathrm{c}}$ & $(1,590)^{\mathrm{d}}$ & $(-2,514)^{\mathrm{b}}$ & $(-0,454)^{\mathrm{ns}}$ & $(3,924)^{\mathrm{a}}$ & & & \\
\hline
\end{tabular}

Notas: Os números entre parênteses sob os coeficientes são as estatísticas $t$, onde "a" representa significativo ao nível de $1 \%$, "b" significativo ao nível de $5 \%$, "c" significativo ao nível de $10 \%$, "d" significativo ao nível de $15 \%$ e "ns" não significativamente diferente de zero. As variáveis são definidas no item 3.2 do capítulo 3.

Tabela 3.24 Estimativa da equação estrutural da demanda de exportação de madeira serrada de não coníferas para o período de 1970 a 1999 utilizando a taxa de câmbio efetiva real com quatro anos de defasagem $\left(E_{t-4}\right)$

\begin{tabular}{cllllll}
\hline \multicolumn{3}{c}{ Variáveis } & & $\mathbf{R}^{2}$ & $\mathbf{F}$ \\
\hline Constante & $\mathrm{PX}_{\mathrm{t}} / \mathrm{PW}_{\mathrm{t}}$ & $\mathrm{YW}_{\mathrm{t}}$ & $\mathrm{Q}_{\mathrm{t}-1}$ & & \\
\hline$-5,648$ & $-0,347$ & 0,811 & 0,414 & 0,869 & 57,506 \\
$(-2,301)^{\mathrm{b}}$ & $(-1,420)^{\mathrm{c}}$ & $(3,768)^{\mathrm{a}}$ & $(3,598)^{\mathrm{a}}$ & & \\
\end{tabular}

Notas: Os números entre parênteses sob os coeficientes são as estatísticas $t$, onde "a" representa significativo ao nível de $1 \%$, "b" significativo ao nível de $5 \%$, "c" significativo ao nível de $20 \%$ e "ns" não significativo. As variáveis são definidas no item 3.2 do capitulo 3 . 
Tabela 3.25 Estimativa da equação estrutural da oferta de exportação de madeira serrada de não coníferas para o período de 1970 a 1999 utilizando a taxa de câmbio efetiva real com cinco anos de defasagem $\left(E_{t-5}\right)$

\begin{tabular}{|c|c|c|c|c|c|c|}
\hline \multirow[b]{2}{*}{ Constante } & \multicolumn{3}{|c|}{ Variáveis } & & \multirow{2}{*}{$\mathbf{R}^{2}$} & \multirow{2}{*}{$\mathbf{F}$} \\
\hline & $\mathrm{PX}_{\mathrm{t}}$ & $E_{t-5}$ & $Y_{t}$ & $Q_{t-1}$ & & \\
\hline 3,804 & 0,457 & $-0,998$ & 0,318 & 0,468 & 0,862 & 39,117 \\
\hline$(1,992)^{b}$ & $(0,542)^{\mathrm{ns}}$ & $(-3,003)^{a}$ & $(0,793)^{\mathrm{ns}}$ & $(2,999)^{\mathrm{a}}$ & & \\
\hline
\end{tabular}

Tabela 3.26 Estimativa da equação estrutural da demanda de exportação de madeira serrada de não coníferas para o período de 1970 a 1999 utilizando a taxa de câmbio efetiva real com cinco anos de defasagem $\left(E_{t-5}\right)$

\begin{tabular}{ccccccc}
\hline \multicolumn{2}{c}{ Variáveis } & & $\mathbf{R}^{2}$ & $\mathbf{F}$ \\
\hline Constante & $\mathrm{PX}_{\mathrm{t}} / \mathrm{PW}_{\mathrm{t}}$ & $\mathrm{YW}_{\mathrm{t}}$ & $\mathrm{Q}_{\mathrm{t}-1}$ & & \\
\hline$-5,597$ & $-0,369$ & 0,808 & 0,415 & 0,867 & 56,668 \\
$(-2,262)^{\mathrm{b}}$ & $(-1,452)^{\mathrm{c}}$ & $(3,725)^{\mathrm{a}}$ & $(3,578)^{\mathrm{a}}$ & & & \\
\hline
\end{tabular}

Notas: Os números entre parênteses sob os coeficientes são as estatísticas $t$, onde "a" representa significativo ao nível de $1 \%$, "b" significativo ao nível de $5 \%$, "c" representa significativo ao nível de $20 \%$ e "ns" não significativo. As variáveis são definidas no item 3.2 do capitulo 3. 
Tabela 3.27 Estimativa da equação estrutural da oferta de exportação de painéis à base de madeira na forma não restrita para o período de 1961 a 1999

\begin{tabular}{|c|c|c|c|c|c|c|c|}
\hline \multirow[b]{2}{*}{ Constante } & \multicolumn{5}{|c|}{ Variáveis } & \multirow{2}{*}{$\mathbf{R}^{2}$} & \multirow{2}{*}{$\mathbf{F}$} \\
\hline & $\mathrm{PX}_{\mathrm{t}}$ & $\mathrm{E}_{\mathrm{t}}$ & $\mathrm{U}_{\mathrm{t}}$ & $Y_{t}$ & $Q_{t-1}$ & & \\
\hline$-10,151$ & $-9,020$ & 3,279 & 17,721 & $-3,881$ & 3,128 & $-0,212$ & $-1,117$ \\
\hline$(-0,305)^{\mathrm{ns}}$ & $(-0,430)^{\mathrm{ns}}$ & $(0,420)^{\mathrm{ns}}$ & $(0,414)^{\mathrm{ns}}$ & $(-0,401)^{\mathrm{ns}}$ & $(0,569)^{\mathrm{ns}}$ & & \\
\hline
\end{tabular}

Notas: Os números entre parênteses sob os coeficientes são as estatísticas $t$, onde "ns" representa não significativamente diferente de zero. As variáveis são definidas no item 3.2 do capítulo 3.

Tabela 3.28 Estimativa da equação estrutural da demanda de exportação de painéis à base de madeira na forma não restrita para o período de 1961 a 1999

\begin{tabular}{ccccccc}
\hline \multicolumn{3}{c}{ Variáveis } & & $\mathbf{R}^{2}$ & $\mathbf{F}$ \\
\hline Constante & $\mathrm{PX}_{\mathrm{t}} / \mathrm{PW}_{\mathrm{t}}$ & $\mathrm{YW}_{\mathrm{t}}$ & $\mathrm{Q}_{\mathrm{t}-1}$ & & \\
\hline$-3,191$ & $-0,148$ & 0,387 & 0,749 & 0,980 & 551,870 \\
$(-1,624)^{\mathrm{c}}$ & $(-0,801)^{\mathrm{ns}}$ & $(2,034)^{\mathrm{b}}$ & $(7,293)^{\mathrm{a}}$ & &
\end{tabular}

Notas: Os números entre parênteses sob os coeficientes são as estatísticas $t$, onde "a" representa significativo ao nivel de $1 \%$, "b" significativo ao nível de $5 \%$, "c" significativo ao nivel de $15 \%$ e "ns" não significativo. As variáveis são definidas no item 3.2 do capítulo 3. 
Tabela 3.29 Estimativa da equação estrutural da oferta de exportação de painéis à base de madeira para o período de 1961 a 1999 utilizando a taxa de câmbio real bilateral $\left(E_{t}^{*}\right)$

\begin{tabular}{cccccccc}
\hline \multicolumn{5}{c}{ Variáveis } & $\mathbf{R}^{2}$ & $\mathbf{F}$ \\
\hline Constante & $\mathrm{PX}_{\mathrm{t}}$ & $\mathrm{E}_{\mathrm{t}}^{*}$ & $\mathrm{U}_{\mathrm{t}}$ & $\mathrm{Q}_{\mathrm{t}-1}$ & & \\
\hline 0,165 & $-1,189$ & $-0,483$ & $-0,589$ & 0,309 & 0,842 & 44,113 \\
$(0,053)^{\mathrm{ns}}$ & $(-0,213)^{\mathrm{ns}}$ & $(-2,179)^{\mathrm{b}}$ & $(-0,329)^{\mathrm{ns}}$ & $(6,962)^{\mathrm{a}}$ & & &
\end{tabular}

Notas: Os números entre parênteses sob os coeficientes são as estatísticas $t$, onde " $\mathrm{a}$ " representa significativo ao nível de $1 \%$, "b" significativo ao nível de $5 \%$ e "ns" não significativo. As variáveis são definidas no item 3.2 do capítulo 3.

Tabela 3.30 Estimativa da equação estrutural da demanda de exportação de painéis à base de madeira para o período de 1961 a 1999 utilizando a taxa de câmbio real bilateral $\left(E_{t}^{*}\right)$

\begin{tabular}{ccccccc}
\hline \multicolumn{3}{c}{ Variáveis } & & \multirow{2}{*}{$\mathbf{R}^{2}$} & $\mathbf{F}$ \\
\hline Constante & $\mathrm{PX}_{\mathrm{t}} / \mathrm{PW}_{\mathrm{t}}$ & $\mathrm{YW}_{\mathrm{t}}$ & $\mathrm{Q}_{\mathrm{t}-1}$ & & \\
\hline$-2,912$ & $-0,234$ & 0,361 & 0,762 & 0,979 & 516,879 \\
$(-1,432)^{\mathrm{c}}$ & $(-1,208)^{\mathrm{ss}}$ & $(1,836)^{\mathrm{b}}$ & $(7,179)^{\mathrm{a}}$ & & & \\
\hline
\end{tabular}

Notas: Os números entre parênteses sob os coeficientes são as estatísticas $t$, onde "a" representa significativo ao nível de $1 \%$, "b" significativo ao nível de $10 \%$, "c" significativo ao nível de $20 \%$ e "ns" não significativo. As variáveis são definidas no item 3.2 do capítulo 3 . 
Tabela 3.31 Estimativa da equação estrutural da oferta de exportação de painéis à base de madeira para o período de 1961 a 1999 utilizando a taxa de câmbio efetiva real com um ano de defasagem $\left(E_{t-1}\right)$

\begin{tabular}{ccccccc}
\hline \multicolumn{5}{c}{ Variáveis } & \multirow{2}{*}{$\mathbf{R}^{2}$} & $\mathbf{F}$ \\
\cline { 1 - 5 } Constante & $\mathrm{PX}_{\mathrm{t}}$ & $\mathrm{E}_{\mathrm{t}-1}$ & $\mathrm{U}_{\mathrm{t}}$ & $\mathrm{Q}_{\mathrm{t}-1}$ & & \\
\hline$-19,677$ & $-1,502$ & 0,790 & 2,222 & 0,914 & 0,931 & 111,393 \\
$(-6,396)^{\mathrm{a}}$ & $(-2,893)^{\mathrm{a}}$ & $(2,181)^{\mathrm{b}}$ & $(1,519)^{\mathrm{c}}$ & $(5,285)^{\mathrm{a}}$ & & \\
\hline
\end{tabular}

Notas: Os números entre parênteses sob os coeficientes são as estatísticas $t$, onde "a" representa significativo ao nível de $1 \%$, "b" significativo ao nível de $5 \%$, "c" significativo ao nível de $15 \%$ e "ns" não significativamente diferente de zero. As variáveis são definidas no item 3.2 do capítulo 3.

Tabela 3.32 Estimativa da equação estrutural da demanda de exportação de painéis à base de madeira para o período de 1961 a 1999 utilizando a taxa de câmbio efetiva real com um ano de defasagem $\left(E_{t-1}\right)$

\begin{tabular}{cccccc}
\hline \multicolumn{3}{c}{ Variáveis } & & $\mathbf{R}^{2}$ & $\mathbf{F}$ \\
\hline Constante & $\mathrm{PX}_{\mathrm{t}} / \mathrm{PW}_{\mathrm{t}}$ & $\mathrm{YW}_{\mathrm{t}}$ & $\mathrm{Q}_{\mathrm{t}-1}$ & & \\
\hline$-0,507$ & $-0,627$ & 0,150 & 0,856 & 0,941 & 180,024 \\
$(-120)^{\mathrm{ns}}$ & $(-2,858)^{\mathrm{a}}$ & $(0,772)^{\mathrm{ns}}$ & $(11,598)^{\mathrm{a}}$ & & \\
\hline
\end{tabular}

Notas: Os números entre parênteses sob os coeficientes são as estatísticas $t$, onde "a" representa significativo ao nível de 1\% e "ns" não significativo. As variáveis são definidas no item 3.2 do capítulo 3 . 
Tabela 3.33 Estimativa da equação estrutural da oferta de exportação de painéis à base de madeira para o período de 1961 a 1999 utilizando a taxa de câmbio efetiva real com dois anos de defasagem $\left(E_{t-2}\right)$

\begin{tabular}{|c|c|c|c|c|c|c|}
\hline \multirow[b]{2}{*}{ Constante } & \multicolumn{3}{|c|}{ Variáveis } & \multirow[b]{2}{*}{$\mathrm{Q}_{\mathrm{t}-1}$} & \multirow{2}{*}{$\mathbf{R}^{2}$} & \multirow{2}{*}{$\mathbf{F}$} \\
\hline & $\mathrm{PX}_{\mathrm{t}}$ & $E_{t-2}$ & $\mathrm{U}_{\mathrm{t}}$ & & & \\
\hline 2,040 & 0,440 & $-0,700$ & $-1,693$ & 0,326 & 0,886 & 62,031 \\
\hline$(0,969)^{\mathrm{ns}}$ & $(0,910)^{\mathrm{ns}}$ & $(-4,351)^{\mathbf{a}}$ & $(-1,660)^{b}$ & $(9,787)^{a}$ & & \\
\hline
\end{tabular}

Notas: Os números entre parênteses sob os coeficientes são as estatísticas $t$, onde "a" representa significativo ao nível de $1 \%$, "b" significativo ao nível de $15 \%$ e "ns" não significativamente diferente de zero. As variáveis são definidas no item 3.2 do capítulo 3.

Tabela 3.34 Estimativa da equação estrutural da demanda de exportação de painéis à base de madeira para o período de 1961 a 1999 utilizando a taxa de câmbio efetiva real com dois anos de defasagem $\left(E_{t-2}\right)$

\begin{tabular}{|c|c|c|c|c|c|}
\hline \multicolumn{4}{|c|}{ Variáveis } & \multirow{2}{*}{$\mathbf{R}^{2}$} & \multirow{2}{*}{$\mathbf{F}$} \\
\hline Constante & $\mathrm{PX}_{\mathrm{t}} / \mathrm{PW}_{\mathrm{t}}$ & $\mathrm{YW}_{\mathrm{t}}$ & $Q_{t-1}$ & & \\
\hline$-1,784$ & $-0,253$ & 0,293 & 0,765 & 0,984 & 683,620 \\
\hline$(-1,079)^{\mathrm{ns}}$ & $(-1,663)^{b}$ & $(1,856)^{\mathrm{a}}$ & $(9,112)^{a}$ & & \\
\hline
\end{tabular}

Notas: Os números entre parênteses sob os coeficientes são as estatísticas $t$, onde " $\mathrm{a}$ " representa significativo ao nível de $1 \%$, "b" significativo ao nível de $15 \%$ e "ns" não significativo. As variáveis são definidas no item 3.2 do capitulo 3. 
Tabela 3.35 Estimativa da equação estrutural da oferta de exportação de painéis à base de madeira para o período de 1961 a 1999 utilizando a taxa de câmbio efetiva real com três anos de defasagem $\left(E_{t-3}\right)$

\begin{tabular}{ccccccc}
\hline \multicolumn{5}{c}{ Variáveis } & $\mathbf{R}^{2}$ & $\mathbf{F}$ \\
\cline { 1 - 5 } Constante & $\mathrm{PX}_{\mathrm{t}}$ & $\mathrm{E}_{\mathrm{t}-3}$ & $\mathrm{U}_{\mathrm{t}}$ & $\mathrm{Q}_{\mathrm{t}-1}$ & & \\
\hline 3,659 & 0,512 & $-0,814$ & $-2,011$ & 0,316 & 0,867 & 50,475 \\
$(1,786)^{\mathrm{b}}$ & $(0,801)^{\mathrm{ns}}$ & $(-4,747)^{\mathrm{a}}$ & $(-1,621)^{\mathrm{c}}$ & $(6,021)^{\mathrm{a}}$ & &
\end{tabular}

Notas: Os números entre parênteses sob os coeficientes são as estatísticas $t$, onde "a" representa significativo ao nível de $1 \%$, "b" significativo ao nível de $10 \%$, "c" significativo ao nível de $15 \%$ e "ns" não significativamente diferente de zero. As variáveis são definidas no item 3.2 do capítulo 3 .

Tabela 3.36 Estimativa da equação estrutural da demanda de exportação de painéis à base de madeira para o período de 1961 a 1999 utilizando a taxa de câmbio efetiva real com três anos de defasagem $\left(E_{t-3}\right)$

\begin{tabular}{|c|c|c|c|c|c|}
\hline \multicolumn{4}{|c|}{ Variáveis } & \multirow{2}{*}{$\mathbf{R}^{2}$} & \multirow{2}{*}{$\mathbf{F}$} \\
\hline Constante & $\mathrm{PX}_{\mathrm{t}} / \mathrm{PW}_{\mathrm{t}}$ & $\mathrm{YW}_{\mathrm{t}}$ & $\mathrm{Q}_{\mathrm{t}-1}$ & & \\
\hline$-2,142$ & $-0,332$ & 0,369 & 0,694 & 0,984 & 675,425 \\
\hline$(-1,446)^{c}$ & $(-2,217)^{b}$ & $(2,603)^{b}$ & $(8,994)^{a}$ & & \\
\hline
\end{tabular}

Notas: Os números entre parênteses sob os coeficientes são as estatísticas $t$, onde "a" representa significativo ao nível de $1 \%$, "b" significativo ao nivel de $5 \%$ e "c" significativo ao nível de $20 \%$. As variáveis são definidas no item 3.2 do capítulo 3. 
Tabela 3.37 Estimativa da equação estrutural da oferta de exportação de painéis à base de madeira para o período de 1961 a 1999 utilizando a taxa de câmbio efetiva real com quatro anos de defasagem $\left(E_{t-4}\right)$

\begin{tabular}{|c|c|c|c|c|c|c|}
\hline \multicolumn{5}{|c|}{ Variáveis } & \multirow{2}{*}{$\mathbf{R}^{2}$} & \multirow{2}{*}{$\mathbf{F}$} \\
\hline Constante & $\mathrm{PX}_{\mathfrak{t}}$ & $E_{t-4}$ & $\mathrm{U}_{\mathrm{t}}$ & $\mathrm{Q}_{\mathrm{t}-1}$ & & \\
\hline 4,794 & 1,625 & $-1,091$ & $-3,885$ & 0,460 & 0,775 & 25,848 \\
\hline$(1,813)^{c}$ & $(2,272)^{b}$ & $(-4,446)^{\mathrm{a}}$ & $(-3,065)^{\mathrm{a}}$ & $(5,339)^{\mathrm{a}}$ & & \\
\hline
\end{tabular}

Notas: Os números entre parênteses sob os coeficientes são as estatísticas $t$, onde "a" representa significativo ao nível de $1 \%$ " $b$ " significativo ao nível de $5 \%$ e "c" significativo ao nível de $10 \%$. As variáveis são definidas no item 3.2 do capítulo 3.

Tabela 3.38 Estimativa da equação estrutural da demanda de exportação de painéis à base de madeira para o periodo de 1961 a 1999 utilizando a taxa de câmbio efetiva real com quatro anos de defasagem $\left(E_{t-4}\right)$

\begin{tabular}{ccccccc}
\hline \multicolumn{3}{c}{ Variáveis } & & $\mathbf{R}^{2}$ & $\mathbf{F}$ \\
\hline Constante & $\mathrm{PX} / \mathrm{PW}$ & $\mathrm{YW}_{\mathrm{t}}$ & $\mathrm{Q}_{\mathrm{t}-1}$ & & \\
\hline$-2,307$ & $-0,369$ & 0,398 & 0,669 & 0,981 & 538,262 \\
$(-1,518)^{\mathrm{d}}$ & $(-2,018)^{\mathrm{c}}$ & $(2,586)^{\mathrm{b}}$ & $(7,168)^{\mathrm{a}}$ & & & \\
\hline
\end{tabular}

Notas: Os números entre parênteses sob os coeficientes são as estatísticas $t$, onde "a" representa significativo ao nível de $1 \%$, "b" significativo ao nível de $5 \%$, "c" significativo ao nível de $10 \%$ e "d" significativo ao nível de $15 \%$. As variáveis são definidas no item 3.2 do capítulo 3 . 
Tabela 3.39 Estimativa da equação estrutural da oferta de exportação de painéis à base de madeira para o período de 1961 a 1999 utilizando a taxa de câmbio efetiva real com cinco anos de defasagem $\left(E_{t \cdot s}\right)$

\begin{tabular}{|c|c|c|c|c|c|c|}
\hline \multicolumn{5}{|c|}{ Variáveis } & \multirow{2}{*}{$\mathbf{R}^{2}$} & \multirow{2}{*}{$\mathbf{F}$} \\
\hline Constante & $\mathrm{PX}_{\mathrm{t}}$ & $E_{t-5}$ & $\mathrm{U}_{\mathrm{t}}$ & $Q_{t-1}$ & & \\
\hline 0,823 & 1,217 & $-0,735$ & $-2,882$ & 0,491 & 0,797 & 28,458 \\
\hline$(0,268)^{\mathrm{ns}}$ & $(2,103)^{b}$ & $(-2,711)^{b}$ & $(-3,030)^{a}$ & $(5,352)^{a}$ & & \\
\hline
\end{tabular}

Tabela 3.40 Estimativa da equação estrutural da demanda de exportação de painéis à base de madeira para o período de 1961 a 1999 utilizando a taxa de câmbio efetiva real com cinco anos de defasagem $\left(E_{t-5}\right)$

\begin{tabular}{|c|c|c|c|c|c|}
\hline \multicolumn{4}{|c|}{ Variáveis } & \multirow{2}{*}{$\mathbf{R}^{2}$} & \multirow{2}{*}{$\mathbf{F}$} \\
\hline Constante & $\mathrm{PX}_{\downarrow} / \mathrm{PW}_{\mathrm{t}}$ & $\mathrm{YW}_{\mathrm{t}}$ & $\mathrm{Q}_{\mathrm{t}-1}$ & & \\
\hline$-2,448$ & $-0,453$ & 0,445 & 0,620 & 0,978 & 442,141 \\
\hline$(-1,578)^{c}$ & $(-1,677)^{\mathfrak{c}}$ & $(2,622)^{b}$ & $(5,131)^{a}$ & & \\
\hline
\end{tabular}

Notas: Os números entre parênteses sob os coeficientes são as estatísticas $t$, onde "a" representa significativo ao nivel de $1 \%$ "b" significativo ao nivel de $5 \%$ e "c" representa significativo ao nivel de $15 \%$. As variáveis são definidas no item 3.2 do capítulo 3 . 